\title{
Growth Mechanism of SiC Chemical Vapor Deposition: Adsorption and Surface Reactions of Active Si Species
}

Pitsiri Sukkaew, Emil Kalered, ErikJ anzén, Olle Kordina, Örjan Danielsson and Lars Ojamäe

The self-archived postprint version of this journal article is available at Linköping University Institutional Repository (DiVA):

http:// urn.kb.se/ resolve?urn=urn:nbn:se:liu:diva- 144885

N.B.: When citing this work, cite the original publication.

Sukkaew, P., Kalered, E., J anzén, E., Kordina, O., Danielsson, Ö., Ojamäe, L., (2018), Growth

Mechanism of SiC Chemical Vapor Deposition: Adsorption and Surface Reactions of Active Si Species,

The J ournal of Physical Chemistry C, 122(1), 648-661. https:// doi.org/ 10.1021/ acs.jpoc.7b10751

Original publication available at:

https:// doi.org/ 10.1021/acs.jpcc.7b10751

Copyright: American Chemical Society

http://pubs.acs.org/ 


\section{Growth Mechanism of SiC CVD - Adsorption and}

\section{Surface Reactions of Active Si Species}

Pitsiri Sukkaew*, Emil Kalered, Erik Janzén, Olof Kordina, Örjan Danielsson and Lars

Ojamäe*.

Department of Physics, Chemistry and Biology, Linköping University, SE-581 83 Linköping, Sweden.

\section{ABSTRACT}

Silicon carbide is a wide bandgap semiconductor ideally suitable for high temperature and high power applications. An active $\mathrm{SiC}$ layer is usually fabricated using halide-assisted chemical vapor deposition (CVD). In this work, we use quantum chemical density functional theory (B3LYP and M06-2X) and transition state theory to study adsorptions of active Si species in the CVD process on both the Si face and the $\mathrm{C}$ face of $4 \mathrm{H}-\mathrm{SiC}$. We show that adsorptions of $\mathrm{SiCl}_{1} \mathrm{SiCl}_{2}, \mathrm{SiHCl}, \mathrm{SiH}$ and $\mathrm{SiH}_{2}$ on the $\mathrm{Si}$ face likely occurs on a methylene site, $\mathrm{CH}_{2}$ (ads), but the processes are thermodynamically less favorable than their reverse or desorptions. Nevertheless, the adsorbed products become stabilized with help of subsequent surface reactions to form a larger cluster. These cluster formation reactions happen with rates that are fast enough to compete with the desorption processes. On the $\mathrm{C}$ face, the adsorptions likely occur on a surface site terminated by a dangling bond, *(ads), and produce the products which are thermodynamically stable. Lastly, we 
present the Gibbs free energies of adsorptions of $\mathrm{Si}$ atoms, $\mathrm{SiX}, \mathrm{SiX}_{2}$, SiHX, for $\mathrm{X}$ being $\mathrm{F}$ and Br. Adsorptions of Si atoms are shown to be the most thermodynamically favorable among all the species in the study. Among the halide-containing species, the Gibbs free energies $\left(\Delta_{R} G^{\circ}\right)$ from smallest to largest are observed in the adsorptions of $\mathrm{SiX}$, SiHX and $\mathrm{SiX}_{2}$, for X being the halides. The results in this study suggest that the major Si contributors in SiC-CVD process are Si atoms, SiX (for X being the halide) and SiH.

\section{Introduction}

Silicon carbide (SiC) is a wide bandgap semiconductor ideally suitable for high-voltage, power devices ${ }^{1-3}$ and sensors ${ }^{4,5}$. Among $\mathrm{SiC}$ numerous polytypes, the $4 \mathrm{H}$ polytype is a common choice for electronic applications ${ }^{6}$ thanks to its superior characteristics of high breakdown electric field and high mobility ${ }^{1}$. An active layer of $4 \mathrm{H}-\mathrm{SiC}$ is usually fabricated using chemical vapor deposition (CVD). The process is performed at temperatures $\sim 1500-1600{ }^{\circ} \mathrm{C}$ and pressures $\sim 50$ 300 mbar, typically using a mixture of silane $\left(\mathrm{SiH}_{4}\right)$ and light hydrocarbons diluted in the flow of hydrogen. Addition of halides, especially chlorine, is often used to suppress the formation of silicon clusters in the gas phase so that the growth rate can be increased by increasing the precursor concentration ${ }^{7,8}$. It has been shown recently that $\mathrm{Br}$ chemistry worked similarly well in terms of material qualities and growth rates ${ }^{8}$. In addition, F-chemistry was also reported to produce high quality SiC homoepitaxial layer ${ }^{9}$.

CVD processes involve chemical reactions in the gas phase and on the surface. During the process, active species are produced from pyrolysis before transported to the surface and become incorporated into the growing layer. For the F-, Cl- and Br-assisted SiC-CVD conditions, it was shown using thermodynamic equilibrium calculations ${ }^{8,10}$ that the Si species with the highest gas 
phase concentrations are $\mathrm{SiX}, \mathrm{SiX}_{2}$, $\mathrm{SiHX}$ (for $\mathrm{X}$ referring to $\mathrm{F}, \mathrm{Cl}$ and $\mathrm{Br}$ ) as well as $\mathrm{Si}_{2} \mathrm{C}$ and $\mathrm{Si}$ atoms. This suggests that these species might act as the Si growth contributors.

Surface reactions of $\mathrm{SiH}_{2}, \mathrm{SiCl}_{2}$ and $\mathrm{SiBr}_{2}$ were recently reported ${ }^{8,11}$ on the C-face of $4 \mathrm{H}$-SiC. It was shown that $\mathrm{SiCl}_{2}$ and $\mathrm{SiBr}_{2}$ behave similarly for the reactions considered ${ }^{8}$. This suggests that similar reactivity may be expected among different halides. In our recent study, we compare SiF, $\mathrm{SiHF}$ and $\mathrm{SiF}_{2}$ adsorptions on the $\mathrm{Si}$-face of $4 \mathrm{H}-\mathrm{SiC}$ and found that $\mathrm{SiF}$ was the most active species in the set, while $\mathrm{SiF}_{2}$ was the least active species ${ }^{10}$. These studies ${ }^{10,11}$ also showed that at the CVD process temperature, most adsorptions occurred with relatively large, positive Gibbs free energies $\left(\Delta_{\mathrm{R}} \mathrm{G}^{\circ}\right)$. This means that adsorption is less favorable than its reverse.

In our previous work ${ }^{12}$, we presented growth mechanisms of $4 \mathrm{H}-\mathrm{SiC}$ with the focus on active Cspecies adsorptions and their subsequent surface reactions on the Si-face of $4 \mathrm{H}-\mathrm{SiC}$. We showed that hydrocarbon adsorptions occurred with much slower rates than desorptions, but with help of subsequent reactions, the process proceeded forward and produced stable final products. In this work, we continue with adsorptions of active Si-species and their subsequent reactions on both the Si face and the C face. We consider the following Si-species: $\mathrm{SiH}, \mathrm{SiH}_{2}, \mathrm{SiCl}, \mathrm{SiHCl}$, and $\mathrm{SiCl}_{2}$. The adsorption sites on the Si face are $\mathrm{CH}_{3}$ (ads), $\mathrm{CH}_{2}$ (ads) and $\mathrm{C}_{2} \mathrm{H}_{4}$ (ads), as shown in Fig. 1a-c. We have shown in our previous work ${ }^{12}$ that these three surface sites can be produced from adsorptions (and subsequent reactions) of gaseous $\mathrm{CH}_{3}, \mathrm{C}_{2} \mathrm{H}_{2}$ and $\mathrm{C}_{2} \mathrm{H}_{4}$ respectively. On the $\mathrm{C}$ face, we consider two adsorption sites: $\mathrm{H}(\mathrm{ads})$ and *(ads), referring respectively to a surface site (C site) terminated by a hydrogen atom and a dangling bond as shown in Fig. 2a and b. Lastly, we discuss adsorptions of Si atoms as well as F- and Br-chemistries and demonstrate their similarities and differences in terms of reactivity and thermodynamics. 


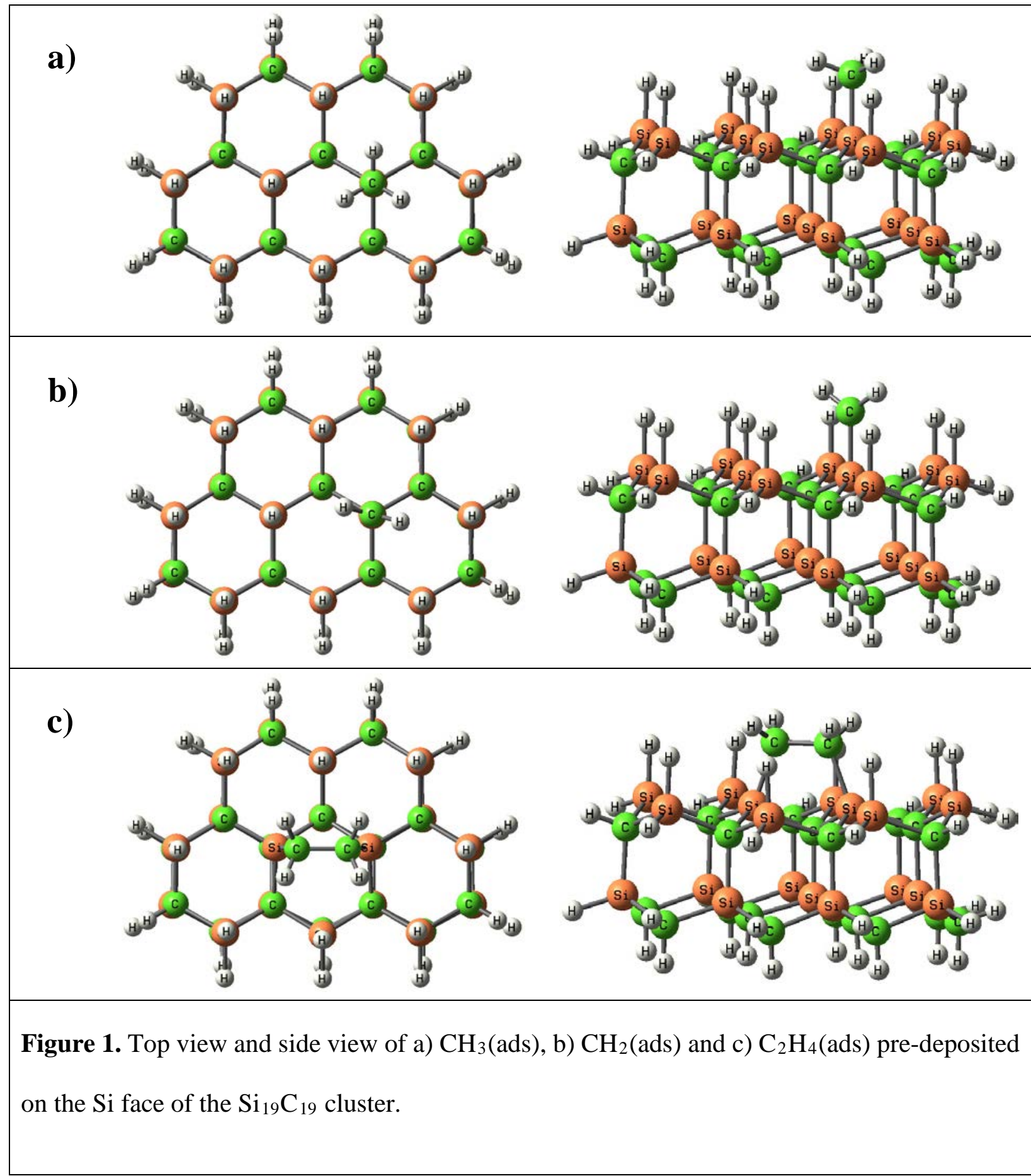




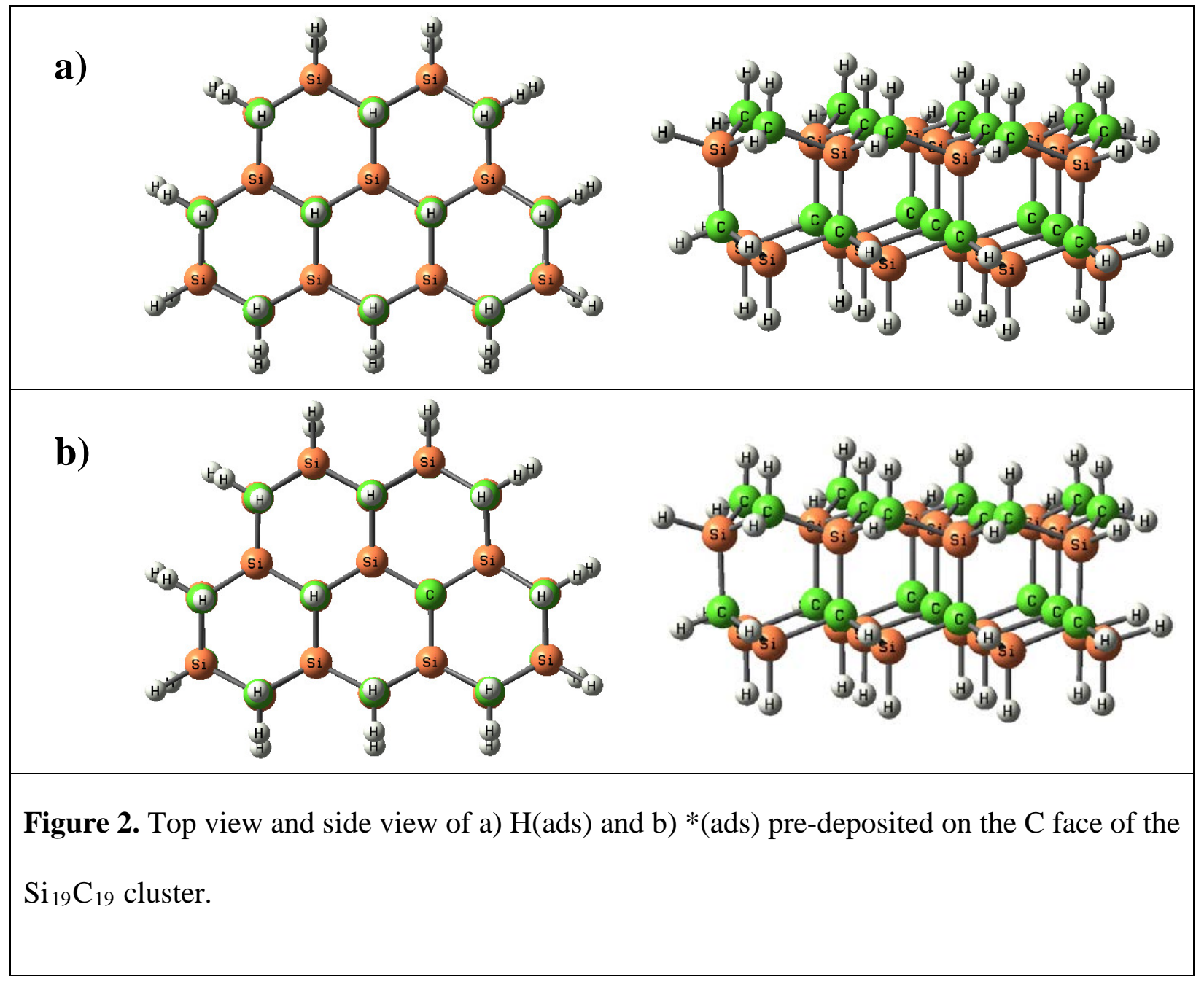

\section{Computational Methods}

The surface of $4 \mathrm{H}-\mathrm{SiC}$ is modeled using $\mathrm{Si}_{19} \mathrm{C}_{19}$ and $\mathrm{Si}_{24} \mathrm{C}_{24}$ clusters. The central surface sites (two on $\mathrm{Si}_{19} \mathrm{C}_{19}$ and three on $\mathrm{Si}_{24} \mathrm{C}_{24}$ ) are chosen for the study. $\mathrm{Si}_{19} \mathrm{C}_{19}$ is used in the calculations of adsorption and the first step of cluster formation, while $\mathrm{Si}_{24} \mathrm{C}_{24}$ is employed in the second step of cluster formation. To preserve the SiC bulk geometry, both clusters are terminated at the edges by hydrogen atoms. Adsorptions are studied on both the Si face and the C face of the cluster. On the Si face, we consider three adsorption sites: $\mathrm{CH}_{3}$ (ads), $\mathrm{CH}_{2}$ (ads) and $\mathrm{C}_{2} \mathrm{H}_{4}$ (ads) as shown in 
Fig. 1a - 1c, while on the $\mathrm{C}$ face, two adsorption sites, $\mathrm{H}(\mathrm{ads})$ and *(ads), are selected as shown in Fig. 2a and b. In this study, *(ads) refers to a surface site terminated by a dangling bond.

All ground state and transition state (TS) structures are optimized using the density functional theory (DFT) with the B3LYP functional ${ }^{13,14}$ and the LanL2DZ basis set ${ }^{15,16}$ together with the D3 dispersion corrections from Grimme et al. ${ }^{17}$. Harmonic frequency calculations are performed at the same level of theory on the optimized structures. B3LYP electronic energies are replaced with the energy calculated using the M06-2X functional ${ }^{18}$ and Dunning's basis set cc-pVTZ ${ }^{19}$. The transition state (TS) structures are verified by visualizing the vibrational displacement associated with the imaginary frequencies. Zero point energy correction is applied to all energies in the study. All quantum chemical calculations are performed using the Gaussian 09 software ${ }^{20}$.

The energies and Gibbs free energies of reaction are derived using

$$
\begin{aligned}
& \Delta_{R} E^{\circ}=\left(\sum E_{\text {products }}^{\circ}\right)-\left(\sum E_{\text {reactants }}^{\circ}\right), \\
& \Delta_{R} G^{\circ}=\left(\sum G_{\text {products }}^{\circ}\right)-\left(\sum G_{\text {reactants }}^{\circ}\right) .
\end{aligned}
$$

The energies and Gibbs free energies of activation are derived using

$$
\begin{aligned}
& \Delta_{T S} E^{\circ}=\left(\sum E_{T S}^{\circ}\right)-\left(\sum E_{\text {reactants }}^{\circ}\right), \\
& \Delta_{T S} G^{\circ}=\left(\sum G_{T S}^{\circ}\right)-\left(\sum G_{\text {reactants }}^{\circ}\right) .
\end{aligned}
$$

$E_{\text {reactants }}^{\circ} E_{\text {products }}^{\circ}, E_{T S}^{\circ}$ refer to the energies of the reactants, products and transition states, respectively. For a reaction involving gas phase species, the ground state energy is defined with respect to the asymptote condition where the surface and the gas are separated at infinite distance. 
This is not to be confused with the physisorbed state, which is known to be unstable at high temperature.

Reaction Rates. The conventional transition state theory (TST) is applied to calculate the rate constant. This implies that rapid equilibrium is assumed between the reactants and activation complex. TST is applicable when a tight transition state exists between the reactant and product states ${ }^{21,22}$. Similar to our previous study ${ }^{12}$, we use the modified rate equations from Reuter and Scheffler's work ${ }^{23}$.

Adsorption. Adsorption rate $\left(R_{a d s}\right)$ of a reaction in the form, $\mathrm{A}(\mathrm{g})+\mathrm{B}(\mathrm{ads}) \rightarrow$ product(ads), is obtained as follows.

$$
R_{a d s}=A_{S} f_{a d s} \exp \left(-\Delta_{T S} E^{\circ} / k_{B} T\right) \cdot \Phi_{A} \cdot \Theta_{B},
$$

Here the adsorption rate $R_{a d s}$ is in the unit of molecule $\operatorname{sites}^{-1} \mathrm{~s}^{-1} . A_{s}$ is the surface area per site of surface species B, assumed equal to the area per one lattice site on the Si face and the C face of $4 \mathrm{H}-\mathrm{SiC}, 8.178 \times 10^{-20} \mathrm{~m}^{2}$ as derived using the lattice constant of $3.073 \AA^{24} . \Delta_{T S} E^{\circ}$ is the activation energy of adsorption at $0 \mathrm{~K} . k_{B}$ and $T$ refer to the Boltzmann constant and the process temperature, respectively. $\Theta_{B}$ is the surface fraction of $\mathrm{B}(\mathrm{ads})$, and $\Phi_{A}$ is the impingement rate of species $\mathrm{A}$ calculated using

$$
\Phi_{A}=\gamma_{A} p / \sqrt{2 \pi m_{A} k_{B} T} .
$$

$\gamma_{A}, p$ and $m_{A}$ refer respectively to the mole fraction of gaseous species $\mathrm{A}$, the total pressure and the mass of gaseous species $\mathrm{A}$. The factor $f_{a d s}$ in Eq. 5 is a factor derived from the partition functions, 


$$
f_{a d s}=\mathrm{q}_{v i b, e l}^{T S} /\left(\mathrm{q}_{2 D-T r a n s}^{\text {gas }} \cdot \mathrm{q}_{\text {int }}^{\text {gas }} \mathrm{q}_{v i b, e l}^{\text {surf }}\right) \text {. }
$$

Here the partition function of a surface species contains only the vibrational and electronic parts, with the translational and rotational parts discarded. This applies to $q^{T S}$ of the transition state and $q^{\text {surf }}$ of a surface species, $\mathrm{B}(\mathrm{ads})$. The partition of the gas, $q^{\text {gas }}$, includes all degrees of freedom except the translation along the reaction coordinate. In Eq. 7, $q^{g a s}$ is divided into two parts. The $\mathrm{q}_{\text {int }}^{\text {gas }}$ contains the vibrational, rotational and electronic parts, while $\mathrm{q}_{2 D-\text { Trans }}^{\text {gas }}$ is the 2-dimensional, translational part of the partition function calculated using $\mathrm{q}_{2 D-\text { Trans }}^{\text {gas }}=A_{S} \cdot 2 \pi m_{A} k_{B} T / h^{2}$. Here we assume that the gaseous species that strike on the surface site must reside within the area $A_{s}$. All partition functions are extracted from the Gaussian 09 calculations ${ }^{20}$.

The sticking coefficient $\left(S_{A}\right)$, which is defined as the probability (from 0 to 1 ) that the gaseous species A will stick on the surface per strike, is calculated using $S_{A}=R_{a d s} /\left(A_{S} \cdot \Phi_{A} \cdot \Theta_{B}\right)$. From Eq. $5-7$, we obtain

$$
S_{A}=f_{a d s} \exp \left(-\Delta_{T S} E^{\circ} / k_{B} T\right)
$$

Desorption. Desorption rate $\left(R_{d e}\right)$ of a reaction in the form, A(ads) $\rightarrow$ product(s), is obtained using

$$
R_{d e}=f_{d e}\left(\frac{k_{B} T}{h}\right) \exp \left(-\Delta_{T S} E^{\circ} / k_{B} T\right) \cdot \Theta_{A}
$$

$\Delta_{T S} E^{\circ}$ is the activation energy of desorption at $0 \mathrm{~K} . \Theta_{A}$ is the fraction of surface occupied by $\mathrm{A}(\mathrm{ads}) . f_{d e}$ is the factor derived from the partition functions,

$$
f_{d e}=\mathrm{q}_{v i b, e l}^{T S} / \mathrm{q}_{v i b, e l}^{a d s} \text {. }
$$


where $q^{T S}$ and $q^{a d s}$ are the partition functions of the transition state and the adsorbed species, A(ads).

On-surface Reaction. Reaction rate of an on-surface reaction in the form, A(ads) + B(ads) $\rightarrow$ product(s), is obtained using

$$
R_{\text {on-surf }}=f_{\text {on-surf }}\left(\frac{k_{B} T}{h}\right) \exp \left(-\Delta_{T S} E^{\circ} / k_{B} T\right) \Theta_{A B}
$$

$\Delta_{T S} E^{\circ}$ is the activation energy of the on-surface reaction at $0 \mathrm{~K} . \Theta_{A B}$ is the surface fraction of a pair of $\mathrm{A}(\mathrm{ads})+\mathrm{B}(\mathrm{ads}) . f_{\text {on-surf }}$ is the factor derived from the partition functions,

$$
f_{\text {on-surf }}=\mathrm{q}_{\text {vibel }, e l}^{T S} / \mathrm{q}_{\text {vib,el }}^{\text {surf }} \text {. }
$$

where $q^{T S}$ and $q^{\text {surf }}$ are the partition functions of the transition state and the pair of A(ads) + B(ads).

\section{Results and Discussion}

This section is divided into three parts. The first and second parts are focused on the adsorptions of $\mathrm{SiH}, \mathrm{SiH}_{2}, \mathrm{SiCl}, \mathrm{SiHCl}$ and $\mathrm{SiCl}_{2}$ and their subsequent surface reactions on the $\mathrm{Si}$ face and on the $\mathrm{C}$ face of $4 \mathrm{H}-\mathrm{SiC}$. The last subsection is focused on the adsorptions of Si atoms and of $\mathrm{SiX}$, SiHX and $\mathrm{SiX}_{2}$ for $\mathrm{X}$ being $\mathrm{F}$ and $\mathrm{Br}$, which leads to the discussion of the similarities and dissimilarities between the different CVD chemistries.

\section{Adsorptions and surface reactions on the Si face of $4 \mathrm{H}-\mathrm{SiC}$.}


1.1 Adsorptions. We consider three types of adsorption sites on the Si face: $\mathrm{CH}_{3}$ (ads), $\mathrm{CH}_{2}$ (ads) and $\mathrm{C}_{2} \mathrm{H}_{4}$ (ads), which are the products of surface reactions of $\mathrm{CH}_{3}, \mathrm{C}_{2} \mathrm{H}_{4}$ and $\mathrm{C}_{2} \mathrm{H}_{2}$ gases as reported in our previous work ${ }^{12}$.

Adsorptions on $\mathrm{CH}_{3}$ (ads) of $\mathrm{SiH}, \mathrm{SiH}_{2}$, $\mathrm{SiCl}, \mathrm{SiHCl}$, and $\mathrm{SiCl}_{2}$ gases occur by breaking a C-H bond in $\mathrm{CH}_{3}$ (ads) and forming a new $\mathrm{C}-\mathrm{Si}$ bond and $\mathrm{Si}-\mathrm{H}$ bond. Fig. 3a and b show the transition state and the product of $\mathrm{SiH}$ adsorption on $\mathrm{CH}_{3}$ (ads). Adsorptions of $\mathrm{SiH}, \mathrm{SiH}_{2}, \mathrm{SiCl}, \mathrm{SiHCl}$, and $\mathrm{SiCl}_{2}$ gases all produce large energy barriers $\left(\Delta_{\mathrm{TS}} \mathrm{G}^{\circ}\right)$ and positive changes in the Gibbs free energies, $\Delta_{\mathrm{R}} \mathrm{G}^{\circ}$, at $1600{ }^{\circ} \mathrm{C}$ which is the temperature typically used in SiC CVD process. Large energy barriers $\left(\Delta_{\mathrm{TS}} \mathrm{G}^{\circ}\right)$ lead to very low sticking coefficients for all species, as shown for R1 R5 in Table 1 . The positive $\Delta_{\mathrm{R}} \mathrm{G}^{\circ}$ indicate that desorption, i.e. the reverse of the adsorption reaction, is thermodynamically more favorable and that desorption rates are faster than adsorption rates, as shown in Table 2.

The reactivity of $\mathrm{CH}_{3}$ (ads) can be enhanced, for example by abstraction of an $\mathrm{H}$ atom

$$
\mathrm{CH}_{3} \text { (ads) }+\mathrm{H}(\mathrm{g}) \rightarrow \mathrm{CH}_{2} \text { (ads) }+\mathrm{H}_{2} \text { (g) }
$$

which occurs with $\Delta_{R} G^{\circ}$ and $\Delta_{T S} G^{\circ}$ of -82 and $248 \mathrm{~kJ} / \mathrm{mol}$ at $1600{ }^{\circ} \mathrm{C}^{12}$. The H-abstraction process R16 creates a dangling bond on the $\mathrm{C}$ site and thereby increasing its reactivity. As a result, adsorptions of Si species on $\mathrm{CH}_{2}$ (ads) are more favorable than on $\mathrm{CH}_{3}$ (ads) as shown in $\mathrm{R} 6$ - $\mathrm{R} 10$ in Table 1. In addition, adsorptions of Si species on $\mathrm{CH}_{2}$ (ads) also occur without the presence of transition states. However, their $\Delta_{R} G^{\circ}$ are positive, meaning that desorptions are again more favorable and occur with faster rates, as shown in Table 2. 
Now let us move on to adsorptions of $\mathrm{Si}$ species on a $\mathrm{C}_{2} \mathrm{H}_{4}$ (ads) molecule. $\mathrm{A}_{2} \mathrm{H}_{4}$ (ads) molecule is a product of $\mathrm{C}_{2} \mathrm{H}_{2}$ adsorption and its subsequent reactions ${ }^{12}$. Similar to $\mathrm{CH}_{3}$ (ads), the $\mathrm{C}_{2} \mathrm{H}_{4}$ (ads) molecule has no surface dangling bond. Thus, adsorptions on $\mathrm{C}_{2} \mathrm{H}_{4}(\mathrm{ads})$ species require breaking of the $\mathrm{C}-\mathrm{C}$ bond in the molecule before new Si-C bonds can be formed. Figure $4 \mathrm{a}$ and $\mathrm{b}$ show the transition state and the product of $\mathrm{SiH}$ adsorption on a $\mathrm{C}_{2} \mathrm{H}_{4}$ (ads) molecule. Similar to the adsorptions on $\mathrm{CH}_{3}$ (ads), adsorptions of $\mathrm{Si}$ species on $\mathrm{C}_{2} \mathrm{H}_{4}$ (ads) species create large energy barriers $\left(\Delta_{\mathrm{TS}} \mathrm{G}^{\circ}\right)$ at $1600{ }^{\circ} \mathrm{C}$. It should be noted that despite $\Delta_{\mathrm{R}} \mathrm{G}^{\circ}$ being negative in some cases, all transition barriers $\Delta_{\mathrm{TS}} \mathrm{G}^{\circ}$ are significantly larger than the other adsorption sites considered previously. This is likely due to the species itself being more stable. As a result, the sticking coefficients of the Si species are the lowest on $\mathrm{C}_{2} \mathrm{H}_{4}$ (ads) species. $\mathrm{C}_{2} \mathrm{H}_{4}$ (ads) species is thus the least active adsorption site considered here. In addition, their large transition barriers also make it hard for desorptions to occur via the direct reverse of R11 - R15. The formation of two Si-C bonds thus helps stabilizing the surface species.

Similar to $\mathrm{CH}_{3}$ (ads), the reactivity of $\mathrm{C}_{2} \mathrm{H}_{4}$ (ads) species can be enhanced by interacting with a hydrogen atom,

$$
\mathrm{C}_{2} \mathrm{H}_{4} \text { (ads) }+\mathrm{H}(\mathrm{g}) \rightarrow \mathrm{CH}_{2} \text { (ads) }+\mathrm{CH}_{3} \text { (ads) }
$$

which occurs with $\Delta_{R} G^{\circ}$ and $\Delta_{T S} G^{\circ}$ of 1 and $295 \mathrm{~kJ} / \mathrm{mol}$ at $1600{ }^{\circ} \mathrm{C}$, as shown in Table 1 . Reaction R17 breaks the C-C bond within the species and creates a dangling bond on one of the $\mathrm{C}$ atoms. Adsorptions of $\mathrm{Si}$ species on the newly created $\mathrm{CH}_{2}$ (ads) occur without the presence of a transition state and their products are accompanied by an adjacent $\mathrm{CH}_{3}$ (ads).

In conclusion, from the sticking coefficients listed in Table 1, we find that the adsorption processes with the largest sticking coefficients $(S)$ are as follows: adsorption of $\mathrm{SiH}$ on $\mathrm{CH}_{3}$ (ads) $(S=$ 
$\left.3 \times 10^{-4}\right)$, adsorption of $\mathrm{SiCl}$ on $\mathrm{CH}_{3}$ (ads) $\left(S=4 \times 10^{-5}\right)$, adsorption of $\mathrm{SiH}_{2}$ on $\mathrm{CH}_{3}$ (ads) $(\mathrm{S}=$ $\left.3 \times 10^{-5}\right)$ and adsorption of $\mathrm{SiH}$ on $\mathrm{C}_{2} \mathrm{H}_{4}\left(\right.$ ads) species $\left(S=9 \times 10^{-6}\right)$. The growth rate $V_{H}$ associated with each adsorption can be obtained using $V_{H}=R_{a d s} \cdot h_{M L}$, with $h_{M L}$ being the height of one SiC bilayer, $\sim 2.5131 \times 10^{-10} \mathrm{~m}$. We assume $\Theta$ of 1.0 for both $\mathrm{CH}_{3}$ (ads) and $\mathrm{C}_{2} \mathrm{H}_{4}$ (ads) species which are their maximum values. The molar fractions, $\Phi$, of the Si-species were taken from thermodynamic equilibrium calculations at $1600{ }^{\circ} \mathrm{C}\left(\Phi \sim 10^{-5}\right.$ for $\mathrm{SiH}$ and $\mathrm{SiH}_{2}, \Phi \sim 10^{-3}$ for $\mathrm{SiCl}$ and $\mathrm{SiCl}_{2}$ and $\Phi \sim 10^{-4}$ for $\mathrm{SiHCl}^{8}$ ). We obtain the following growth rates: $\sim 0.25 \mu \mathrm{m} /$ hour for $\mathrm{SiCl}$ on $\mathrm{CH}_{3}$ (ads), $\sim 0.08 \mu \mathrm{m} /$ hour for $\mathrm{SiCl}$ on $\mathrm{C}_{2} \mathrm{H}_{4}$ (ads) species, $\sim 0.03 \mu \mathrm{m} /$ hour for $\mathrm{SiH}$ on $\mathrm{CH}_{3}$ (ads) and $\sim 0.002 \mu \mathrm{m} /$ hour for $\mathrm{SiH}_{2}$ on $\mathrm{CH}_{3}$ (ads). These growth rates are much too low to contribute significantly to the growth rate observed experimentally, $\sim 100 \mu \mathrm{m} /$ hour $^{7}$. Instead, we may speculate that adsorptions occur more efficiently on $\mathrm{CH}_{2}$ (ads) from their much smaller $\Delta_{R} G^{\circ}$ and lacking of transition states. By assuming the sticking coefficients of the Si species to be 1.0 on $\mathrm{CH}_{2}$ (ads) and using $\Theta$ equal to 1.0 together with the same molar fractions of the $\mathrm{Si}$ species as before, we obtain the growth rates of $84 \mu \mathrm{m} /$ hour for $\mathrm{SiH}, 82 \mu \mathrm{m} /$ hour for $\mathrm{SiH}_{2}, \sim 6 \times 10^{3} \mu \mathrm{m} /$ hour for $\mathrm{SiCl}$ and $\mathrm{SiHCl}$, and $\sim 455 \mu \mathrm{m} /$ hour for $\mathrm{SiCl}_{2}$. These growth rates are much larger than the experimental value because we have assumed $\Theta$ of $\mathrm{CH}_{2}$ (ads) equal to 1.0 , which is the maximum value possible, and we have so far neglected the effects of desorptions. In fact, with their $\Delta_{R} G^{\circ}$ being positive, adsorptions on $\mathrm{CH}_{2}$ (ads) are expected to occur with the rates which are significantly smaller than their desorptions.

Table 1 The energies $(0 \mathrm{~K})$, standard Gibbs free energies $\left(1600^{\circ} \mathrm{C}\right)$ and sticking coefficients of $\mathrm{SiH}, \mathrm{SiH}_{2}$, $\mathrm{SiCl}$, $\mathrm{SiHCl}$ and $\mathrm{SiCl}_{2}$ on $\mathrm{CH}_{3}$ (ads), $\mathrm{CH}_{2}$ (ads) and $\mathrm{C}_{2} \mathrm{H}_{4}$ (ads) species pre-deposited on the Si face of $4 \mathrm{H}-\mathrm{SiC}$. The (free) energies are presented in the unit of $\mathrm{kJ} / \mathrm{mol}$, calculated with respect to the energy of the reactant state at asymptote condition. 


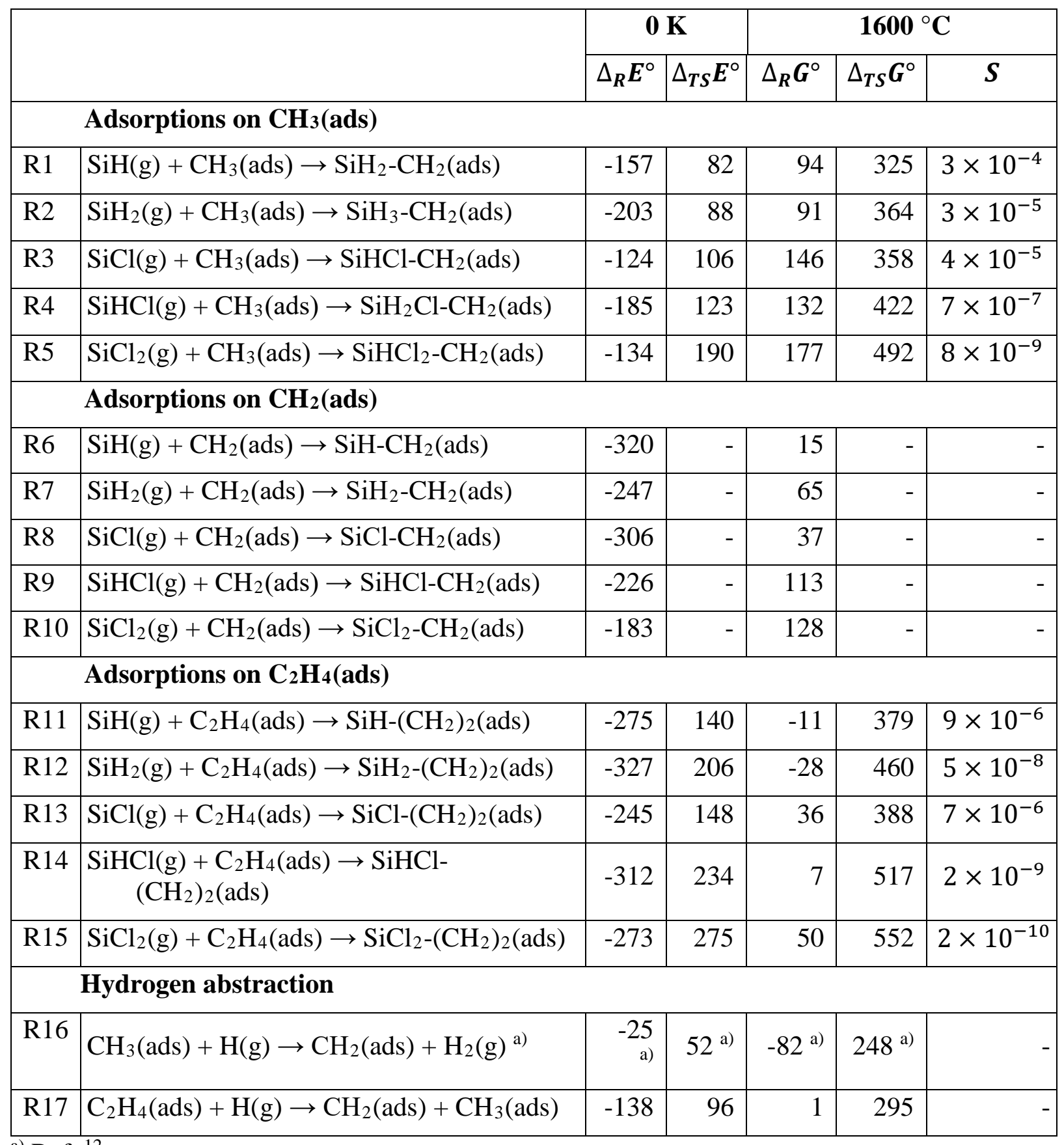

a) Ref. ${ }^{12}$.

Table 2 The adsorption and desorption rate constants at $1600{ }^{\circ} \mathrm{C}$ of $\mathrm{SiH}, \mathrm{SiH}_{2}, \mathrm{SiCl}, \mathrm{SiHCl}$ and $\mathrm{SiCl}_{2}$ on $\mathrm{CH}_{3}$ (ads) and $\mathrm{C}_{2} \mathrm{H}_{4}$ (ads) pre-deposited on the Si face of $4 \mathrm{H}-\mathrm{SiC}$.

\begin{tabular}{|c|c|}
$\begin{array}{c}\text { Adsorption rate } \\
\text { constant }\end{array}$ & $\begin{array}{c}\text { Desorption rate } \\
\text { constant }\end{array}$ \\
\hline
\end{tabular}




\begin{tabular}{|c|c|c|c|}
\hline \multicolumn{4}{|c|}{ Adsorptions on $\mathrm{CH}_{3}$ (ads) } \\
\hline R1 & $\mathrm{SiH}(\mathrm{g})+\mathrm{CH}_{3}(\mathrm{ads}) \rightarrow \mathrm{SiH}_{2}-\mathrm{CH}_{2}$ (ads) & $3 \times 10^{-1}$ & $1 \times 10^{7}$ \\
\hline R2 & $\mathrm{SiH}_{2}(\mathrm{~g})+\mathrm{CH}_{3}(\mathrm{ads}) \rightarrow \mathrm{SiH}_{3}-\mathrm{CH}_{2}$ (ads) & $2 \times 10^{-2}$ & $1 \times 10^{6}$ \\
\hline R3 & $\mathrm{SiCl}(\mathrm{g})+\mathrm{CH}_{3}(\mathrm{ads}) \rightarrow \mathrm{SiHCl}^{-\mathrm{CH}_{2}}$ (ads) & $3 \times 10^{-2}$ & $5 \times 10^{7}$ \\
\hline R4 & $\mathrm{SiHCl}(\mathrm{g})+\mathrm{CH}_{3}(\mathrm{ads}) \rightarrow \mathrm{SiH}_{2} \mathrm{Cl}-\mathrm{CH}_{2}$ (ads) & $4 \times 10^{-4}$ & $3 \times 10^{5}$ \\
\hline R5 & $\mathrm{SiCl}_{2}(\mathrm{~g})+\mathrm{CH}_{3}(\mathrm{ads}) \rightarrow \mathrm{SiHCl}_{2}-\mathrm{CH}_{2}$ (ads) & $4 \times 10^{-6}$ & $6 \times 10^{4}$ \\
\hline \multicolumn{4}{|c|}{ Adsorptions on $\mathrm{C}_{2} \mathrm{H}_{4}$ (ads) } \\
\hline R11 & $\mathrm{SiH}(\mathrm{g})+\mathrm{C}_{2} \mathrm{H}_{4}$ (ads) $\rightarrow \mathrm{SiH}-\left(\mathrm{CH}_{2}\right)_{2}$ (ads) & $2 \times 10^{-2}$ & $5 \times 10^{2}$ \\
\hline R12 & $\mathrm{SiH}_{2}(\mathrm{~g})+\mathrm{C}_{2} \mathrm{H}_{4}(\mathrm{ads}) \rightarrow \mathrm{SiH}_{2}-\left(\mathrm{CH}_{2}\right)_{2}$ (ads) & $9 \times 10^{-5}$ & $9 \times 10^{-1}$ \\
\hline R13 & $\mathrm{SiCl}(\mathrm{g})+\mathrm{C}_{2} \mathrm{H}_{4}(\mathrm{ads}) \rightarrow \mathrm{SiCl}-\left(\mathrm{CH}_{2}\right)_{2}$ (ads) & $8 \times 10^{-3}$ & $6 \times 10^{3}$ \\
\hline R14 & $\mathrm{SiHCl}(\mathrm{g})+\mathrm{C}_{2} \mathrm{H}_{4}$ (ads) $\rightarrow \mathrm{SiHCl}-\left(\mathrm{CH}_{2}\right)_{2}$ (ads) & $2 \times 10^{-6}$ & $2 \times 10^{-1}$ \\
\hline R15 & $\mathrm{SiCl}_{2}(\mathrm{~g})+\mathrm{C}_{2} \mathrm{H}_{4}$ (ads) $\rightarrow \mathrm{SiCl}_{2}-\left(\mathrm{CH}_{2}\right)_{2}$ (ads) & $2 \times 10^{-7}$ & $4 \times 10^{-1}$ \\
\hline
\end{tabular}

a) The adsorption rate constants, $R_{a d s} / p \gamma_{g} \Theta_{s}$, are calculated using Eq. 5-8. Here, the adsorption rate $\left(R_{\text {ads }}\right)$ is in molecule per site per second. The total pressure $(p)$ is in Pascal. The gaseous molar fraction $\left(\gamma_{g}\right)$ and the surface fraction $\left(\Theta_{s}\right)$ are unitless. The surface area per site of $\mathrm{CH}_{3}$ (ads) is assumed equal to $8.178 \times 10^{-20} \mathrm{~m}^{2}$ which is the area per one lattice site on the Si-face of $4 \mathrm{H}-\mathrm{SiC}$. The area per site of $\mathrm{C}_{2} \mathrm{H}_{4}(\mathrm{ads})$ is assumed equal to $1.636 \times 10^{-19} \mathrm{~m}^{2}$ which is the area per two lattice sites.

b) The desorption rate constants, $R_{d e} / \Theta_{s}$, are calculated using Eq. 9-10. Here, the desorption rate $\left(R_{d e}\right)$ is in molecule per site per second. The surface fraction $\left(\Theta_{s}\right)$ is unitless. 


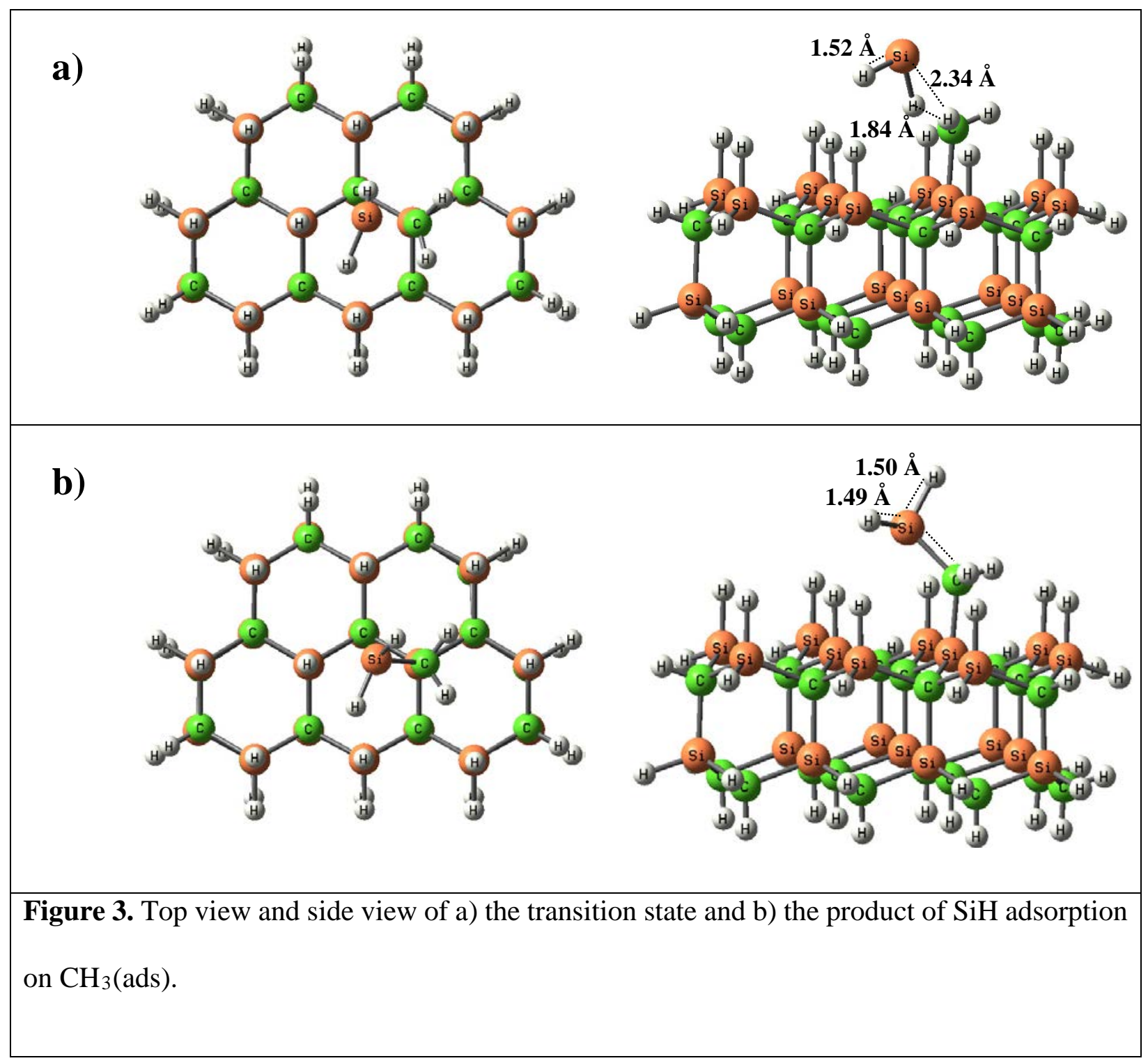




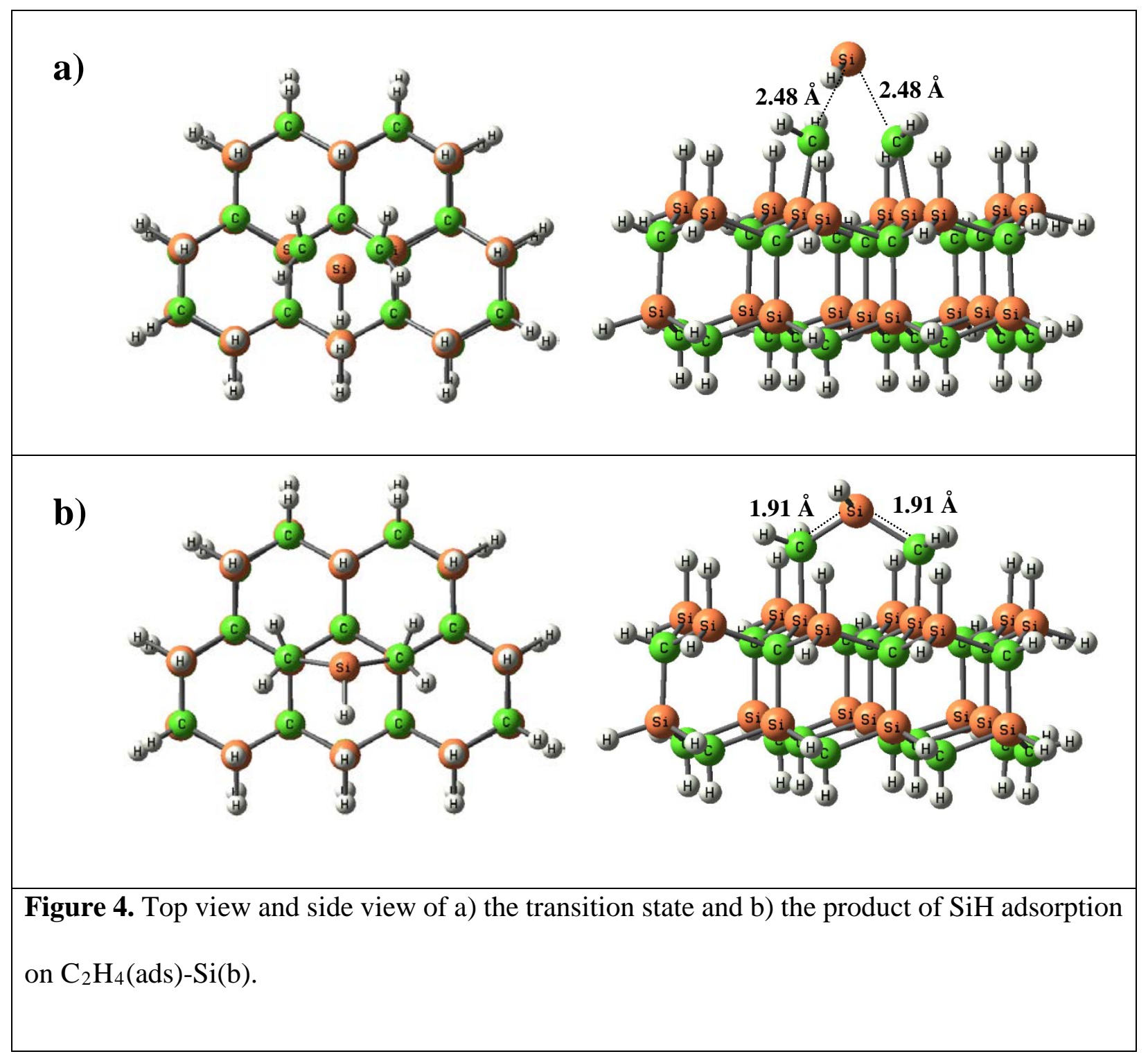

1.2. Cluster formations. In the previous subsection, we showed that based on the rate derived it is unlikely for adsorptions on $\mathrm{CH}_{3}$ (ads) and on $\mathrm{C}_{2} \mathrm{H}_{4}$ (ads) species to contribute significantly to the growth. It could be that the main adsorption route occurs mainly via $\mathrm{CH}_{2}$ (ads). We also show that adsorptions on $\mathrm{CH}_{3}$ (ads), $\mathrm{C}_{2} \mathrm{H}_{4}$ (ads) and $\mathrm{CH}_{2}$ (ads) all occur with positive $\Delta_{R} G^{\circ}$. Thus, for all processes considered, desorptions are more favorable than adsorptions. In order for the growth to proceed in the forward direction, it is thus necessary that there are subsequent reaction path(s) 
following adsorptions which helps reducing the total $\Delta_{R} G^{\circ}$ and stabilizing the final products. In addition, this path(s) should occur with a rate that is fast enough, at least comparable to that of the desorption rate. We propose that one route for this is by formation of larger surface species, or a cluster.

In the first step following adsorptions, let us consider a bonding process between the adsorbed species and an adjacent $\mathrm{CH}_{3}(\mathrm{ads})$, as shown in R18-R22 in Table 3. In Figure 5a-c, we show an example of $\mathrm{SiH}-\mathrm{CH}_{2}$ (ads), which is the product of $\mathrm{SiH}$ adsorption on $\mathrm{CH}_{2}$ (ads), forming a bond with its adjacent $\mathrm{CH}_{3}$ (ads). This process occurs by breaking a C-H bond in $\mathrm{CH}_{3}$ (ads) and forming new C-Si and Si-H bonds. As shown in Table 3, the processes R18-R22 are thermodynamically preferable with negative $\Delta_{R} G^{\circ}$ at $1600{ }^{\circ} \mathrm{C}$. In addition, their transition barriers are relatively small, especially for the interactions R18 and R20, resulting in the forward rate constants as high as $10^{9}$ molecule site ${ }^{-1}$ second $^{-1}$ as shown in Table 4 . These rates are fast enough to compete with desorption processes. From the rate constants shown in Table 4, it should be noted that R19, R20 and R22 which are the subsequent reactions following the adsorptions of $\mathrm{SiH}_{2}, \mathrm{SiHCl}_{\text {and }} \mathrm{SiCl}_{2}$, are $100-1000$ times slower than R18 and R20 which are the subsequent reactions following the adsorptions of $\mathrm{SiH}$ and $\mathrm{SiCl}$. This together with the fact that $\Delta_{R} G^{\circ}$ of $\mathrm{SiH}_{2}, \mathrm{SiHCl}$ and $\mathrm{SiCl}_{2}$ adsorptions are much more positive than $\Delta_{R} G^{\circ}$ of $\mathrm{SiH}$ and $\mathrm{SiCl}$ adsorptions implies that the growth contributions from $\mathrm{SiH}_{2}, \mathrm{SiHCl}$ and $\mathrm{SiCl}_{2}$ are likely much less than from $\mathrm{SiH}$ and $\mathrm{SiCl}$.

Following this step, the surface species can be stabilized further by forming another Si-C bond with another $\mathrm{CH}_{3}$ (ads) via R23-R26 shown in Table 3. An example of an interaction between $\mathrm{SiH}_{2}-\left(\mathrm{CH}_{2}\right)_{2}$ (ads) and an adjacent $\mathrm{CH}_{3}$ (ads), which is the reaction following R18, is shown in Fig. 6a-c. Via these two steps, $\mathrm{SiC}$ growth via $\mathrm{SiH}$ adsorption may proceed as follows, 


$$
\begin{aligned}
& \mathrm{SiH}(\mathrm{g})+\mathrm{CH}_{2} \text { (ads) } \rightarrow \mathrm{SiH}-\mathrm{CH}_{2} \text { (ads), } \\
& \mathrm{SiH}-\mathrm{CH}_{2} \text { (ads) }+\mathrm{CH}_{3} \text { (ads) } \rightarrow \mathrm{SiH}_{2}-\left(\mathrm{CH}_{2}\right)_{2} \text { (ads), }
\end{aligned}
$$

and

$$
\mathrm{SiH}_{2}-\left(\mathrm{CH}_{2}\right)_{2} \text { (ads) }+\mathrm{CH}_{3}(\mathrm{ads}) \rightarrow \mathrm{SiH}-\left(\mathrm{CH}_{2}\right)_{3}(\mathrm{ads})+\mathrm{H}_{2}(\mathrm{~g})
$$

These steps produce $\mathrm{SiH}-\left(\mathrm{CH}_{2}\right)_{3}$ (ads) as the final product and produces a total change in $\Delta_{R} G^{\circ}$ of $-366 \mathrm{~kJ} / \mathrm{mol}$ at $1600{ }^{\circ} \mathrm{C}$. The step-by-step change in the Gibbs free energy is depicted in Fig 7. Similarly, $\mathrm{SiH}_{2}$ adsorption and subsequent reactions are as follows

$$
\begin{aligned}
& \mathrm{SiH}_{2}(\mathrm{~g})+\mathrm{CH}_{2} \text { (ads) } \rightarrow \mathrm{SiH}_{2}-\mathrm{CH}_{2} \text { (ads), } \\
& \mathrm{SiH}_{2}-\mathrm{CH}_{2} \text { (ads) }+\mathrm{CH}_{3}(\text { ads }) \rightarrow \mathrm{SiH}_{2}-\left(\mathrm{CH}_{2}\right)_{2}(\text { ads })+\mathrm{H}(\mathrm{g}),
\end{aligned}
$$

and

$$
\mathrm{SiH}_{2}-\left(\mathrm{CH}_{2}\right)_{2} \text { (ads) }+\mathrm{CH}_{3}(\mathrm{ads}) \rightarrow \mathrm{SiH}-\left(\mathrm{CH}_{2}\right)_{3}(\text { ads })+\mathrm{H}_{2} \text { (g) } .
$$

This leads to the production of $\mathrm{SiH}-\left(\mathrm{CH}_{2}\right)_{3}($ ads $)$ with a total change in $\Delta_{R} G^{\circ}$ of $-238 \mathrm{~kJ} / \mathrm{mol}$ at $1600{ }^{\circ} \mathrm{C}$.

$\mathrm{SiCl}$ adsorption and subsequent reactions may occur via two different routes, as shown in Fig. 8.

$$
\begin{aligned}
& \mathrm{SiCl}(\mathrm{g})+\mathrm{CH}_{2} \text { (ads) } \rightarrow \mathrm{SiCl}-\mathrm{CH}_{2} \text { (ads), } \\
& \mathrm{SiCl}-\mathrm{CH}_{2} \text { (ads) }+\mathrm{CH}_{3} \text { (ads) } \rightarrow \mathrm{SiHCl}-\left(\mathrm{CH}_{2}\right)_{2} \text { (ads), }
\end{aligned}
$$

and 


$$
\mathrm{SiHCl}-\left(\mathrm{CH}_{2}\right)_{2} \text { (ads) }+\mathrm{CH}_{3} \text { (ads) } \rightarrow \mathrm{SiH}-\left(\mathrm{CH}_{2}\right)_{3}(\mathrm{ads})+\mathrm{HCl}(\mathrm{g})
$$

or

$$
\mathrm{SiHCl}-\left(\mathrm{CH}_{2}\right)_{2} \text { (ads) }+\mathrm{CH}_{3} \text { (ads) } \rightarrow \mathrm{SiCl}-\left(\mathrm{CH}_{2}\right)_{3} \text { (ads) }+\mathrm{H}_{2} \text { (g) }
$$

The product $\mathrm{SiH}-\left(\mathrm{CH}_{2}\right)_{3}$ (ads) occurs via the combination of R8, R20 and R24 with a total change in $\Delta_{R} G^{\circ}$ of $-260 \mathrm{~kJ} / \mathrm{mol}$ at $1600{ }^{\circ} \mathrm{C}$, while the product $\mathrm{SiCl}-\left(\mathrm{CH}_{2}\right)_{3}$ (ads) occurs by replacing $\mathrm{R} 24$ with R25 and produces a total change in $\Delta_{R} G^{\circ}$ of $-318 \mathrm{~kJ} / \mathrm{mol}$ at $1600{ }^{\circ} \mathrm{C}$. It should be noted that $\Delta_{T S} G^{\circ}$ of R24 and R25 are relatively similar (269 and $289 \mathrm{~kJ} / \mathrm{mol}$ ). Thus, the two processes are highly competitive to each other.

$\mathrm{SiHCl}$ adsorption and subsequent reactions occurs as follows,

$$
\begin{aligned}
& \mathrm{SiHCl}(\mathrm{g})+\mathrm{CH}_{2} \text { (ads) } \rightarrow \text { SiHCl-CH} \text { (ads), } \\
& \mathrm{SiHCl}-\mathrm{CH}_{2} \text { (ads) }+\mathrm{CH}_{3}(\text { ads }) \rightarrow \mathrm{SiHCl}-\left(\mathrm{CH}_{2}\right)_{2}(\text { ads })+\mathrm{H}(\mathrm{g}),
\end{aligned}
$$
(R21)

and

$$
\mathrm{SiHCl}-\left(\mathrm{CH}_{2}\right)_{2} \text { (ads) }+\mathrm{CH}_{3} \text { (ads) } \rightarrow \mathrm{SiH}-\left(\mathrm{CH}_{2}\right)_{3} \text { (ads) }+\mathrm{HCl}(\mathrm{g})
$$

or

$$
\mathrm{SiHCl}-\left(\mathrm{CH}_{2}\right)_{2} \text { (ads) }+\mathrm{CH}_{3}(\text { ads }) \rightarrow \mathrm{SiCl}-\left(\mathrm{CH}_{2}\right)_{3}(\text { ads })+\mathrm{H}_{2} \text { (g) }
$$


The product $\mathrm{SiH}-\left(\mathrm{CH}_{2}\right)_{3}$ (ads) occurs via the combination of R9, R21 and R24 with a total change of $-138 \mathrm{~kJ} / \mathrm{mol}$ in $\Delta_{R} G^{\circ}$ at $1600{ }^{\circ} \mathrm{C}$, while the product $\mathrm{SiCl}-\left(\mathrm{CH}_{2}\right)_{3}$ (ads) occurs by replacing $\mathrm{R} 24$ with R25 producing a total change in $\Delta_{R} G^{\circ}$ of $-196 \mathrm{~kJ} / \mathrm{mol}$ at $1600{ }^{\circ} \mathrm{C}$.

Adsorption of $\mathrm{SiCl}_{2}$ and its subsequent reactions produce $\mathrm{SiCl}-\left(\mathrm{CH}_{2}\right)_{3}(\mathrm{ads})$ with the change in $\Delta_{R} G^{\circ}$ of $-139 \mathrm{~kJ} / \mathrm{mol}$ at $1600{ }^{\circ} \mathrm{C}$. This happens via

$$
\begin{aligned}
& \mathrm{SiCl}_{2}(\mathrm{~g})+\mathrm{CH}_{2}(\text { ads }) \rightarrow \mathrm{SiCl}_{2}-\mathrm{CH}_{2} \text { (ads), } \\
& \mathrm{SiCl}_{2}-\mathrm{CH}_{2} \text { (ads) }+\mathrm{CH}_{3}(\mathrm{ads}) \rightarrow \mathrm{SiCl}_{2}-\left(\mathrm{CH}_{2}\right)_{2}(\text { ads })+\mathrm{H}(\mathrm{g}),
\end{aligned}
$$

and

$$
\mathrm{SiCl}_{2}-\left(\mathrm{CH}_{2}\right)_{2} \text { (ads) }+\mathrm{CH}_{3}(\mathrm{ads}) \rightarrow \mathrm{SiCl}-\left(\mathrm{CH}_{2}\right)_{3}(\mathrm{ads})+\mathrm{HCl}(\mathrm{g})
$$

Let us now consider reactions R27 and R28,

$$
\mathrm{SiH}-\left(\mathrm{CH}_{2}\right)_{3}(\mathrm{ads})+\mathrm{H}(\mathrm{g}) \rightarrow \mathrm{Si}^{*}-\left(\mathrm{CH}_{2}\right)_{3}(\mathrm{ads})+\mathrm{H}_{2}(\mathrm{~g})
$$

and

$$
\mathrm{SiCl}-\left(\mathrm{CH}_{2}\right)_{3}(\mathrm{ads})+\mathrm{H}(\mathrm{g}) \rightarrow \mathrm{Si}^{*}-\left(\mathrm{CH}_{2}\right)_{3}(\mathrm{ads})+\mathrm{HCl}(\mathrm{g}),
$$

which help creating a surface dangling bond, $\mathrm{Si}^{*}-\left(\mathrm{CH}_{2}\right)_{3}(\mathrm{ads})$, which was shown to be important for hydrocarbon adsorptions for the next layer ${ }^{12}$. As shown in Table 3 and 4 , it is more difficult to remove Cl-termination in comparison to H-termination. Nevertheless, as the CVD process condition is known to produce a significant amount of $\mathrm{H}$ atoms in the gas phase ${ }^{25}$, the rates of R27 and R28 likely occur much faster than adsorptions. 
Table 3 The energies $(0 \mathrm{~K})$ and standard Gibbs free energies $\left(1600^{\circ} \mathrm{C}\right)$ of the clustering process. The (free) energies are presented in the unit of $\mathrm{kJ} / \mathrm{mol}$.

\begin{tabular}{|c|c|c|c|c|c|}
\hline & \multicolumn{2}{|c|}{$0 \mathrm{~K}$} & \multicolumn{2}{|c|}{$1600^{\circ} \mathrm{C}$} \\
\hline & & $\Delta_{R} E^{\circ}$ & $\Delta_{T S} E^{\circ}$ & $\Delta_{R} G^{\circ}$ & $\Delta_{T S} G^{\circ}$ \\
\hline \multicolumn{6}{|c|}{$1^{\text {st }}$ step of cluster formation process } \\
\hline R18 & $\mathrm{SiH}-\mathrm{CH}_{2}$ (ads) $+\mathrm{CH}_{3}(\mathrm{ads}) \rightarrow \mathrm{SiH}_{2}-\left(\mathrm{CH}_{2}\right)_{2}$ (ads) & -219 & 95 & -158 & 151 \\
\hline R19 & $\begin{array}{l}\mathrm{SiH}_{2}-\mathrm{CH}_{2}(\mathrm{ads})+\mathrm{CH}_{3}(\mathrm{ads}) \rightarrow \mathrm{SiH}_{2}-\left(\mathrm{CH}_{2}\right)_{2} \text { (ads) } \\
+\mathrm{H}(\mathrm{g})\end{array}$ & 57 & 177 & -80 & 246 \\
\hline R20 & 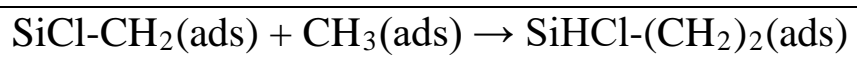 & -182 & 142 & -140 & 176 \\
\hline R21 & 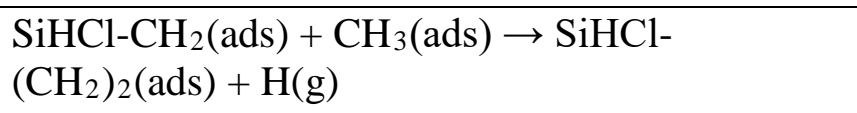 & 46 & 167 & -94 & 235 \\
\hline R22 & $\begin{array}{l}\mathrm{SiCl}_{2}-\mathrm{CH}_{2} \text { (ads) }+\mathrm{CH}_{3}(\mathrm{ads}) \rightarrow \mathrm{SiCl}_{2-} \\
\left(\mathrm{CH}_{2}\right)_{2}(\mathrm{ads})+\mathrm{H}(\mathrm{g})\end{array}$ & 43 & 189 & -100 & 228 \\
\hline \multicolumn{6}{|c|}{$2^{\text {nd }}$ step of cluster formation process } \\
\hline R23 & $\begin{array}{l}\mathrm{SiH}_{2}-\left(\mathrm{CH}_{2}\right)_{2}(\mathrm{ads})+\mathrm{CH}_{3}(\mathrm{ads}) \rightarrow \mathrm{SiH}- \\
\left(\mathrm{CH}_{2}\right)_{3}(\mathrm{ads})+\mathrm{H}_{2}(\mathrm{~g})\end{array}$ & -34 & 292 & -223 & 309 \\
\hline R24 & $\begin{array}{l}\mathrm{SiHCl}-\left(\mathrm{CH}_{2}\right)_{2} \text { (ads) }+\mathrm{CH}_{3}(\mathrm{ads}) \rightarrow \mathrm{SiH}- \\
\left(\mathrm{CH}_{2}\right)_{3}(\mathrm{ads})+\mathrm{HCl}(\mathrm{g})\end{array}$ & 59 & 231 & -157 & 269 \\
\hline R25 & $\begin{array}{l}\mathrm{SiHCl}-\left(\mathrm{CH}_{2}\right)_{2}(\mathrm{ads})+\mathrm{CH}_{3}(\mathrm{ads}) \rightarrow \mathrm{SiCl}- \\
\left(\mathrm{CH}_{2}\right)_{3}(\mathrm{ads})+\mathrm{H}_{2}(\mathrm{~g})\end{array}$ & -44 & 266 & -215 & 289 \\
\hline R26 & $\begin{array}{l}\mathrm{SiCl}_{2}-\left(\mathrm{CH}_{2}\right)_{2}(\mathrm{ads})+\mathrm{CH}_{3}(\mathrm{ads}) \rightarrow \mathrm{SiCl}- \\
\left(\mathrm{CH}_{2}\right)_{3}(\mathrm{ads})+\mathrm{HCl}(\mathrm{g})\end{array}$ & 37 & 243 & -167 & 288 \\
\hline \multicolumn{6}{|c|}{ Surface dangling bond creation } \\
\hline R27 & $\begin{array}{l}\mathrm{SiH}-\left(\mathrm{CH}_{2}\right)_{3}(\mathrm{ads})+\mathrm{H}(\mathrm{g}) \rightarrow \mathrm{Si}^{*}-\left(\mathrm{CH}_{2}\right)_{3}(\mathrm{ads})+ \\
\mathrm{H}_{2}(\mathrm{~g})\end{array}$ & -63 & 12 & -77 & 181 \\
\hline R28 & $\begin{array}{l}\mathrm{SiCl}-\left(\mathrm{CH}_{2}\right)_{3}(\mathrm{ads})+\mathrm{H}(\mathrm{g}) \rightarrow \mathrm{Si}^{*}-\left(\mathrm{CH}_{2}\right)_{3}(\mathrm{ads})+ \\
\mathrm{HCl}(\mathrm{g})\end{array}$ & 40 & 90 & -19 & 258 \\
\hline
\end{tabular}

Table 4 The forward and reverse rate constants of subsequent reactions at $1600{ }^{\circ} \mathrm{C}$ in the unit of molecule per site per second. 


\begin{tabular}{|c|c|c|c|}
\hline & & Forward rate constants & Reverse rate constants \\
\hline \multicolumn{4}{|c|}{$1^{\text {st }}$ step of cluster formation process } \\
\hline R18 & $\begin{array}{l}\mathrm{SiH}_{-}-\mathrm{CH}_{2} \text { (ads) }+\mathrm{CH}_{3}(\text { ads }) \rightarrow \\
\mathrm{SiH}_{2}-\left(\mathrm{CH}_{2}\right)_{2} \text { (ads) }\end{array}$ & $2 \times 10^{9}$ a) & $9 \times 10^{4}$ a) \\
\hline R19 & $\begin{array}{l}\mathrm{SiH}_{2}-\mathrm{CH}_{2}(\mathrm{ads})+\mathrm{CH}_{3}(\mathrm{ads}) \rightarrow \\
\mathrm{SiH}_{2}-\left(\mathrm{CH}_{2}\right)_{2} \text { (ads) }+\mathrm{H}(\mathrm{g})\end{array}$ & $5 \times 10^{6}$ a) & $\left.6 \times 10^{-1} \mathrm{~b}\right)$ \\
\hline R20 & $\begin{array}{l}\mathrm{SiCl}-\mathrm{CH}_{2} \text { (ads) }+\mathrm{CH}_{3}(\text { ads }) \rightarrow \\
\mathrm{SiHCl}-\left(\mathrm{CH}_{2}\right)_{2} \text { (ads) }\end{array}$ & $5 \times 10^{8}$ a) & $6 \times 10^{4}$ a) \\
\hline R21 & $\begin{array}{l}\mathrm{SiHCl}-\mathrm{CH}_{2} \text { (ads) }+\mathrm{CH}_{3}(\mathrm{ads}) \rightarrow \\
\mathrm{SiHCl}-\left(\mathrm{CH}_{2}\right)_{2} \text { (ads) }+\mathrm{H}(\mathrm{g})\end{array}$ & $1 \times 10^{7}$ a) & $\left.5 \times 10^{-1} b\right)$ \\
\hline R22 & $\begin{array}{l}\mathrm{SiCl}_{2}-\mathrm{CH}_{2}(\mathrm{ads})+\mathrm{CH}_{3}(\mathrm{ads}) \rightarrow \\
\mathrm{SiCl}_{2}-\left(\mathrm{CH}_{2}\right)_{2}(\mathrm{ads})+\mathrm{H}(\mathrm{g})\end{array}$ & $2 \times 10^{7}$ a) & $\left.5 \times 10^{-1} b\right)$ \\
\hline \multicolumn{4}{|c|}{$2^{\text {nd }}$ step of cluster formation process } \\
\hline R23 & $\begin{array}{l}\mathrm{SiH}_{2}-\left(\mathrm{CH}_{2}\right)_{2} \text { (ads) }+\mathrm{CH}_{3}(\mathrm{ads}) \rightarrow \\
\mathrm{SiH}-\left(\mathrm{CH}_{2}\right)_{3}(\mathrm{ads})+\mathrm{H}_{2}(\mathrm{~g})\end{array}$ & $1 \times 10^{5}$ a) & $2 \times 10^{-6}$ b) \\
\hline R24 & $\begin{array}{l}\mathrm{SiHCl}-\left(\mathrm{CH}_{2}\right)_{2} \text { (ads) }+\mathrm{CH}_{3} \text { (ads) } \\
\rightarrow \mathrm{SiH}-\left(\mathrm{CH}_{2}\right)_{3} \text { (ads) }+\mathrm{HCl}(\mathrm{g})\end{array}$ & $1 \times 10^{6}$ a) & $\left.1 \times 10^{-3} b\right)$ \\
\hline R25 & $\begin{array}{l}\mathrm{SiHCl}-\left(\mathrm{CH}_{2}\right)_{2} \text { (ads) }+\mathrm{CH}_{3} \text { (ads) } \\
\rightarrow \mathrm{SiCl}-\left(\mathrm{CH}_{2}\right)_{3} \text { (ads) }+\mathrm{H}_{2} \text { (g) }\end{array}$ & $3 \times 10^{5}$ a) & $3 \times 10^{-6 b)}$ \\
\hline R26 & $\begin{array}{l}\mathrm{SiCl}_{2}-\left(\mathrm{CH}_{2}\right)_{2}(\mathrm{ads})+\mathrm{CH}_{3}(\mathrm{ads}) \rightarrow \\
\mathrm{SiCl}-\left(\mathrm{CH}_{2}\right)_{3} \text { (ads) } \mathrm{HCl}(\mathrm{g})\end{array}$ & $4 \times 10^{5}$ a) & $6 \times 10^{-5}$ b) \\
\hline \multicolumn{4}{|c|}{ Surface dangling bond creation } \\
\hline R27 & $\begin{array}{l}\mathrm{SiH}-\left(\mathrm{CH}_{2}\right)_{3}(\mathrm{ads})+\mathrm{H}(\mathrm{g}) \rightarrow \mathrm{Si}^{*}- \\
\left(\mathrm{CH}_{2}\right)_{3}(\mathrm{ads})+\mathrm{H}_{2} \text { (g) }\end{array}$ & $\left.3 \times 10^{4} b\right)$ & $\left.7 \times 10^{1} b\right)$ \\
\hline R28 & $\begin{array}{l}\mathrm{SiCl}-\left(\mathrm{CH}_{2}\right)_{3}(\mathrm{ads})+\mathrm{H}(\mathrm{g}) \rightarrow \mathrm{Si}^{*}- \\
\left(\mathrm{CH}_{2}\right)_{3}(\mathrm{ads})+\mathrm{HCl}(\mathrm{g})\end{array}$ & $\left.7 \times 10^{1} b\right)$ & $\left.2 \times 10^{1} b\right)$ \\
\hline
\end{tabular}

a) Calculated using Eq. 9-10. The rate constant is defined as $R / \Theta_{s}$ where $R$ is the reaction rate in molecule per site per second and $\Theta_{s}$ is the surface fraction which is unitless.

b) Calculated using Eq. 5-8. The rate constant is defined as $R / p \gamma_{g} \Theta_{S}$ where the reaction rate $(R)$ is in molecule per site per second, the total pressure $(p)$ is in pascal, and the gaseous molar fraction $\left(\gamma_{g}\right)$ and the surface fraction $\left(\Theta_{s}\right)$ are unitless. The surface area per site of $\mathrm{SiH}_{\mathrm{n}} \mathrm{X}_{\mathrm{m}}-\mathrm{CH}_{2}$ (ads) is assumed equal to $8.178 \times 10^{-20} \mathrm{~m}^{2}$ which is the area per one lattice site on the Si-face of $4 \mathrm{H}-\mathrm{SiC}$. 
The areas per site of $\mathrm{SiH}_{\mathrm{n}} \mathrm{X}_{\mathrm{m}}-\left(\mathrm{CH}_{2}\right)_{2}$ (ads) and $\mathrm{SiX}-\left(\mathrm{CH}_{2}\right)_{3}(\mathrm{ads})$ are assumed equal to $1.636 \times 10^{-19}$ and $2.453 \times 10^{-19} \mathrm{~m}^{2}$ respectively, which are the areas per two and three lattice sites on the Si-face of $4 \mathrm{H}-\mathrm{SiC}$.

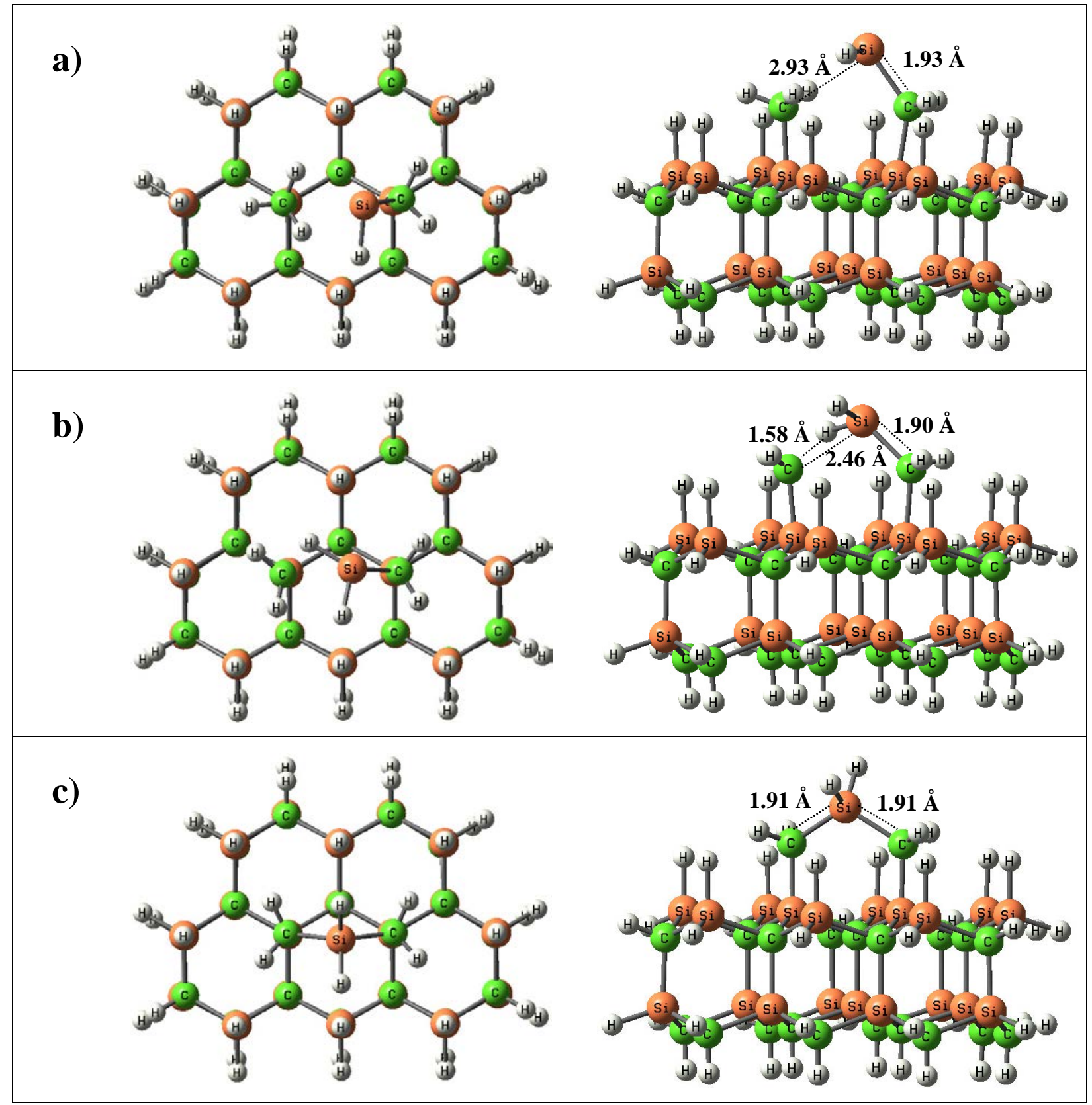


Figure 5 Top view and side view of a) the reactants, b) the transition state, and b) the product of $1^{\text {st }}$ step of cluster formation between $\mathrm{SiH}-\mathrm{CH}_{2}$ (ads) and an adjacent $\mathrm{CH}_{3}$ (ads).

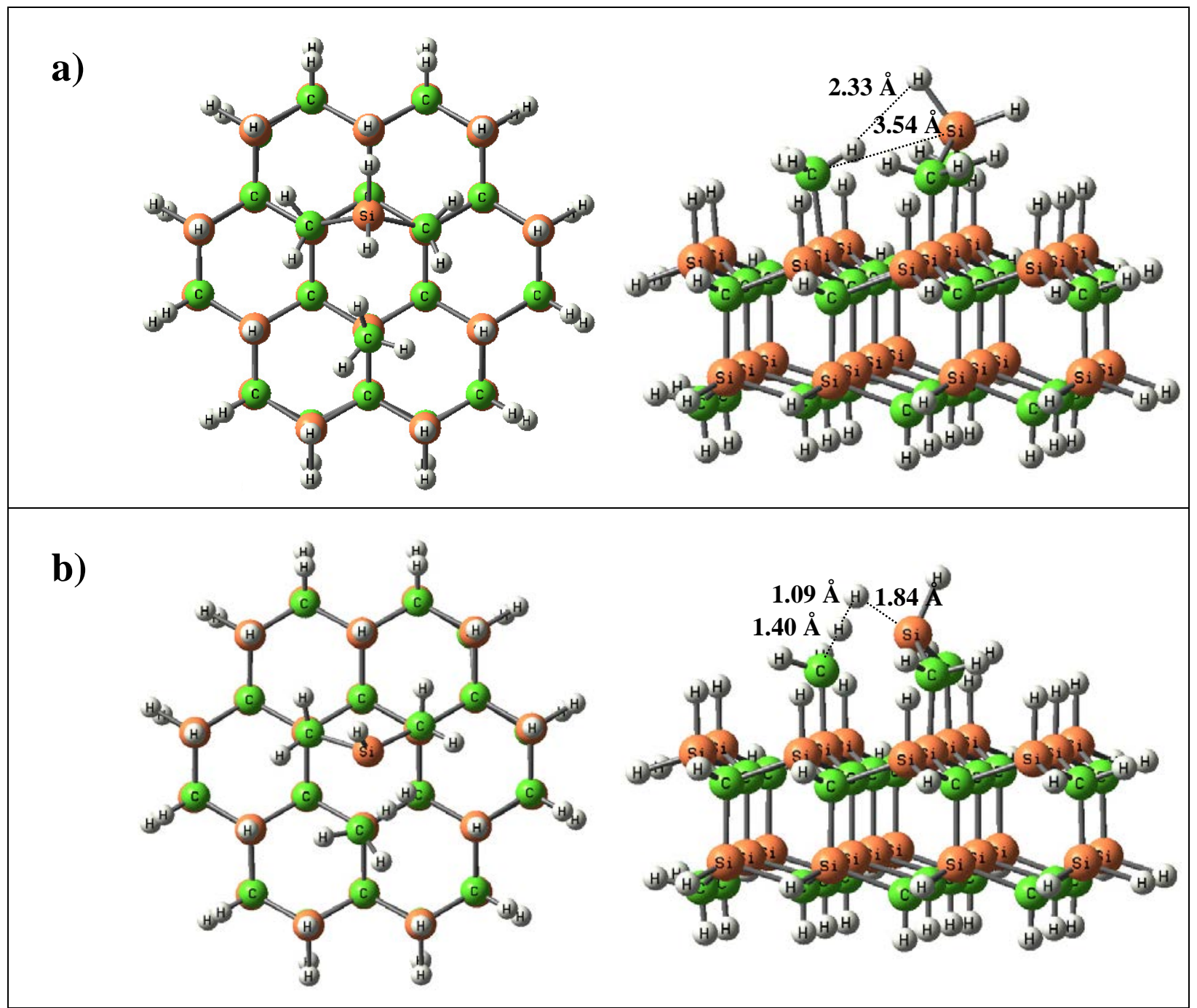




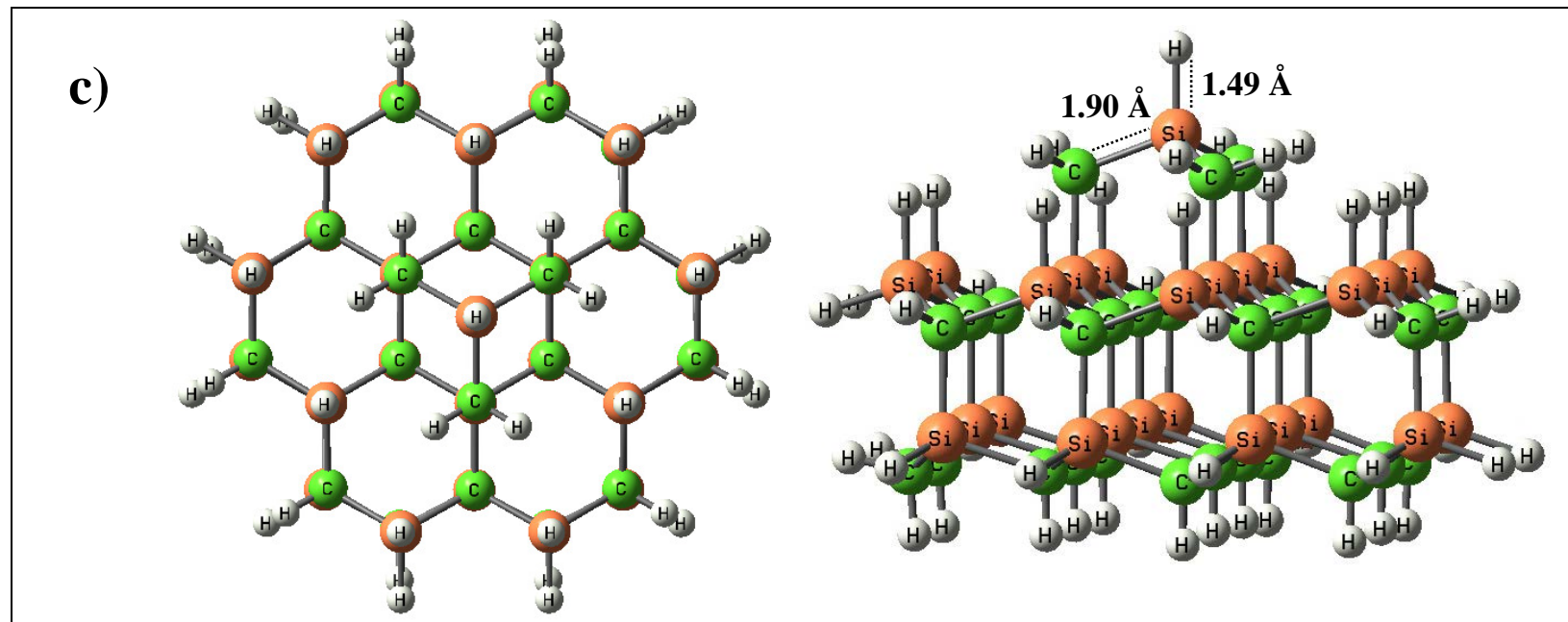

Figure 6 Top view and side view of a) the reactants, b) the transition state, and b) the product of $2^{\text {nd }}$ step of cluster formation between $\mathrm{SiH}_{2}-\left(\mathrm{CH}_{2}\right)_{2}$ (ads) and an adjacent $\mathrm{CH}_{3}$ (ads). 


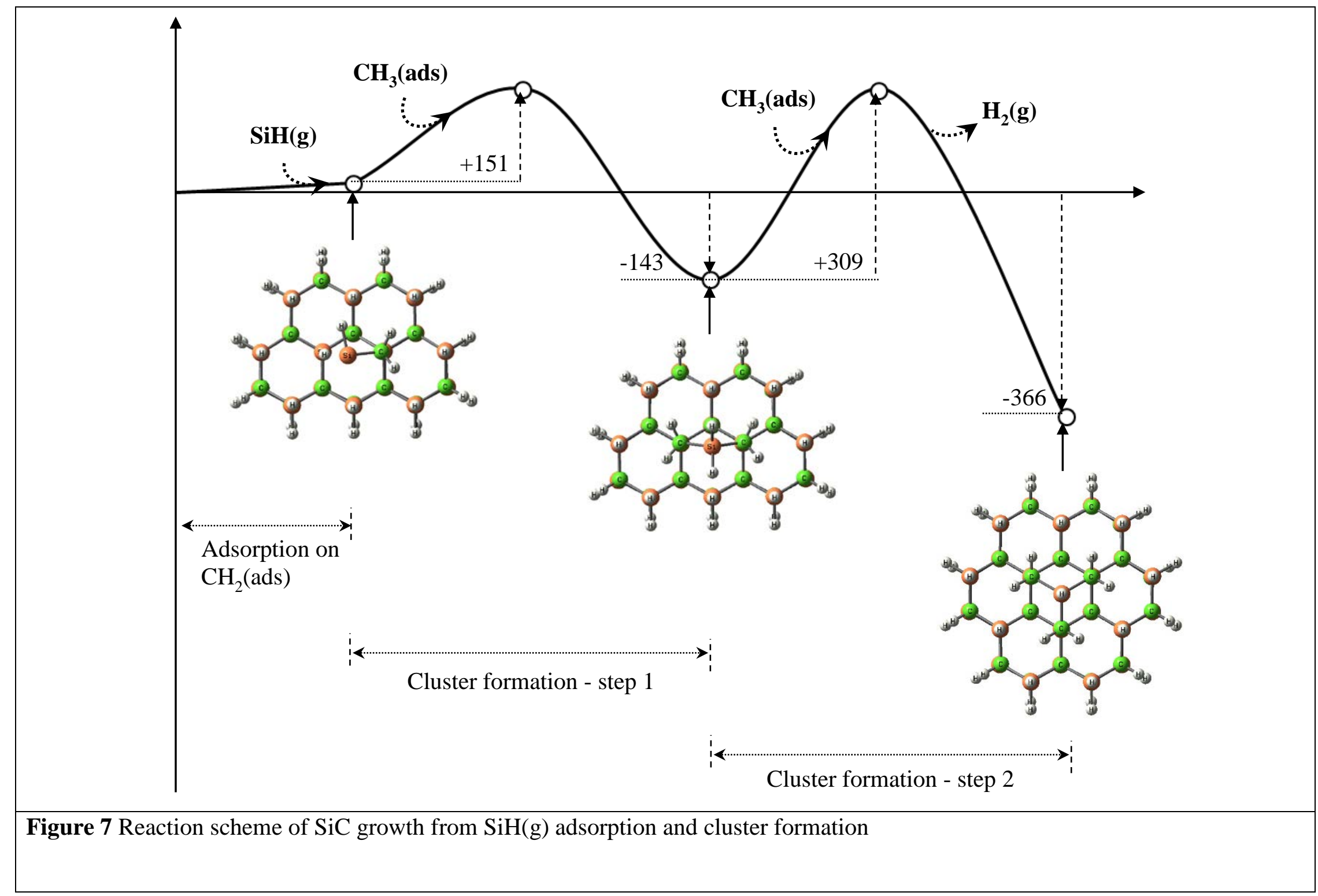




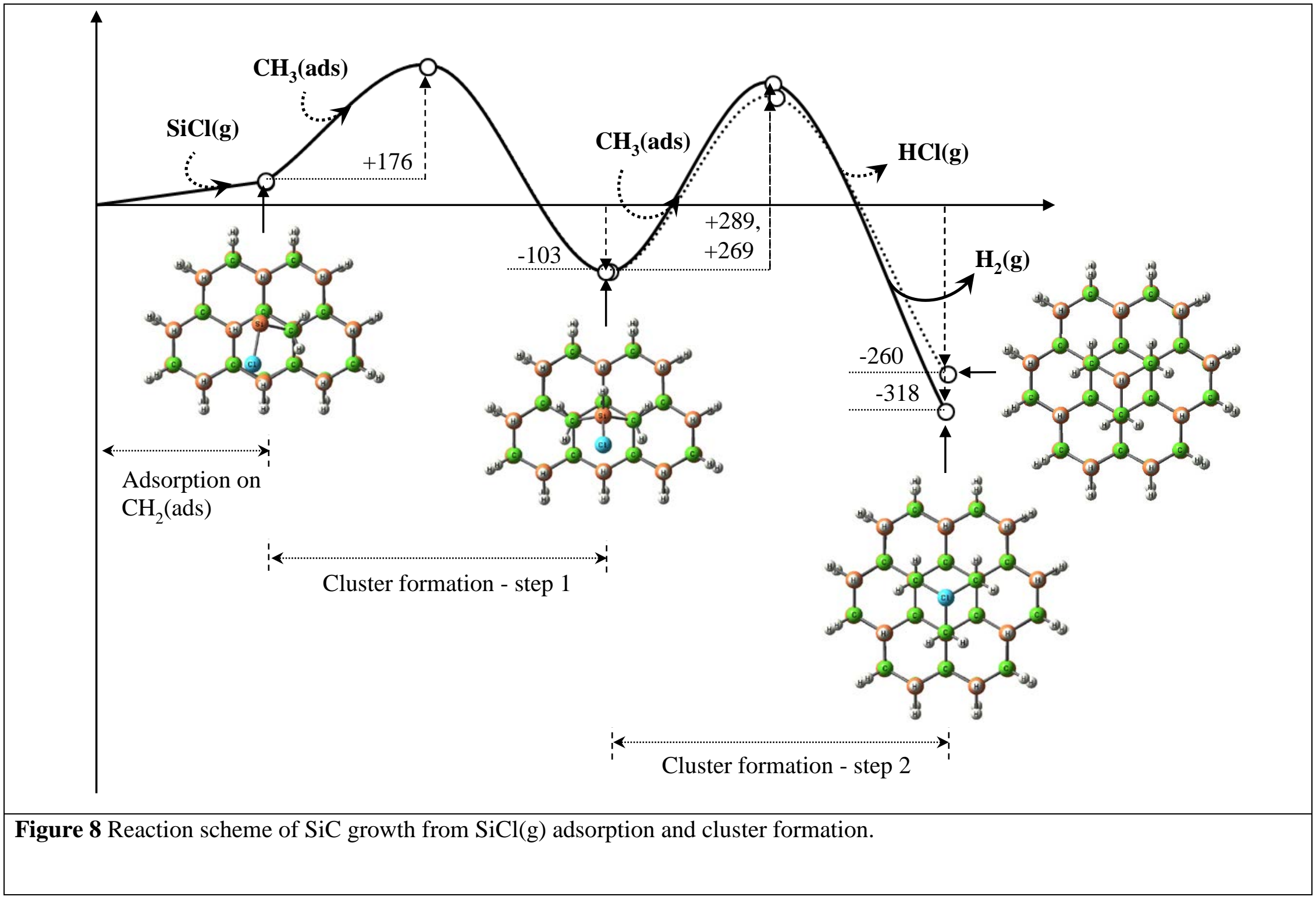


2 Adsorptions on the $\mathbf{C}$ face of $\mathbf{4 H}$-SiC. Here we consider two types of surface sites: H(ads) and *(ads), which refer respectively to a surface site on the $\mathrm{C}$ face terminated by an $\mathrm{H}$ atom and by a dangling bond. Adsorptions of the Si-species on H(ads) occurs by breaking a C-H bond and forming a Si-H bond and a Si-C bond as shown in Fig. 9a and b. The processes are present with large energy barriers $\left(\Delta_{T S} G^{\circ}\right)$ together with large positive $\Delta_{R} G^{\circ}$ as shown in Table 5 . This results in low sticking coefficients for all adsorbing species. As shown in Table 5, the sticking coefficients on $\mathrm{H}$ (ads) from largest to smallest are $\mathrm{SiH}>\mathrm{SiCl}>\mathrm{SiH}_{2} \gg \mathrm{SiHCl} \gg \mathrm{SiCl}_{2}$. With the growth rate $V_{H}$ obtained using $V_{H}=R_{a d s} \cdot h_{M L}$, with $h_{M L}$ being $2.5131 \times 10^{-10} \mathrm{~m}$, and using $\Theta$ equal to 1.0 together with the same molar fractions of the Si species similar to section 1.1, we obtain the adsorption rates (from highest to lowest) to be $\sim 1.1 \mu \mathrm{m} /$ hour for $\mathrm{SiCl} ; \sim 0.2 \mu \mathrm{m} /$ hour for $\mathrm{SiH}$; $\sim 0.005 \mu \mathrm{m} /$ hour for $\mathrm{SiH}_{2}$; and smaller for the rest. These rates are again too low to contribute to the growth rate observed experimentally.

Adsorptions of the Si-species on *(ads), on the other hand, occurs with much smaller $\Delta_{R} G^{\circ}$ and without transition states due to the presence of the surface dangling bond. *(ads) can be created from $\mathrm{H}(\mathrm{ads})$ via an interaction with a hydrogen atom,

$$
\mathrm{H}(\mathrm{ads})+\mathrm{H}(\mathrm{g}) \rightarrow *(\mathrm{ads})+\mathrm{H}_{2}(\mathrm{~g}),
$$

which occurs with $\Delta_{R} G^{\circ}$ and $\Delta_{T S} G^{\circ}$ of -46 and $211 \mathrm{~kJ} / \mathrm{mol}$ at $1600{ }^{\circ} \mathrm{C}$. Unlike adsorptions on the Si face, adsorptions of $\mathrm{SiH}, \mathrm{SiH}_{2}$ and $\mathrm{SiCl}$ on ${ }^{*}$ (ads) occur with negative $\Delta_{R} G^{\circ}$ at $1600{ }^{\circ} \mathrm{C}$, as shown in Table 5. This indicates that the adsorbed species on the surface are stable without any help from subsequent reactions. From $\Delta_{R} G^{\circ}$, we might expect the following trend of the adsorption rates (from largest to smallest): $\mathrm{SiH}>\mathrm{SiCl}>\mathrm{SiH}_{2} \gg \mathrm{SiHCl} \gg \mathrm{SiCl}_{2}$, which is the same order as above for $\mathrm{H}(\mathrm{ads})$. Since adsorptions on *(ads) occur without transition states, we might speculate 
fast adsorption rates on *(ads). If we assume the sticking coefficients to be 1.0 for all the Si species on *(ads) and use $\Theta$ equal to 1.0 together with the same molar fractions as used in section 1.1, we will obtain the same growth rates as shown in section 1.1 which are too high in comparison to the experimental values. As we have discussed previously, the exaggeration in the growth rate is likely due to the following facts. 1) $\Theta$ has been assumed equal to its maximum value $(\Theta=1.0)$ and 2) we have not taken desorption processes into account.

Table 5 The energies at $0 \mathrm{~K}$ and standard Gibbs free energies at $1600{ }^{\circ} \mathrm{C}$ of the adsorption processes and sticking coefficients on $\mathrm{H}(\mathrm{ads})$ and $*(\mathrm{ads})$ on the $\mathrm{C}$ face of $4 \mathrm{H}-\mathrm{SiC}$. The (free) energies are presented in the unit of $\mathrm{kJ} / \mathrm{mol}$ and calculated with respect to the energy of the reactant state at asymptote condition.

\begin{tabular}{|c|c|c|c|c|c|c|}
\hline & & $\begin{array}{c}\Delta_{R} E^{\mathrm{o} \text { a })} \\
(0 \mathrm{~K})\end{array}$ & $\begin{array}{c}\Delta_{T S} E^{\mathrm{o} \mathrm{b})} \\
(0 \mathrm{~K})\end{array}$ & $\begin{array}{c}\Delta_{R} G^{\circ \mathrm{a})} \\
\left(1600^{\circ} \mathrm{C}\right)\end{array}$ & $\begin{array}{c}\Delta_{T S} G^{\circ \mathrm{b})} \\
\left(1600^{\circ} \mathrm{C}\right)\end{array}$ & $\begin{array}{c}S^{\mathrm{c})} \\
\left(1600^{\circ} \mathrm{C}\right)\end{array}$ \\
\hline R29 & $\mathrm{SiH}(\mathrm{g})+\mathrm{H}(\mathrm{ads}) \rightarrow \mathrm{SiH}_{2}$ (ads) & -194 & 47 & 63 & 292 & $3 \times 10^{-3}$ \\
\hline R30 & $\mathrm{SiH}_{2}(\mathrm{~g})+\mathrm{H}(\mathrm{ads}) \rightarrow \mathrm{SiH}_{3}(\mathrm{ads})$ & -238 & 61 & 56 & 350 & $6 \times 10^{-5}$ \\
\hline R31 & $\mathrm{SiCl}(\mathrm{g})+\mathrm{H}(\mathrm{ads}) \rightarrow \mathrm{SiHCl}(\mathrm{ads})$ & -149 & 77 & 133 & 336 & $2 \times 10^{-4}$ \\
\hline R32 & $\mathrm{SiHCl}(\mathrm{g})+\mathrm{H}(\mathrm{ads}) \rightarrow \mathrm{SiH}_{2} \mathrm{Cl}(\mathrm{ads})$ & -207 & 116 & 123 & 422 & $8 \times 10^{-7}$ \\
\hline R33 & $\mathrm{SiCl}_{2}(\mathrm{~g})+\mathrm{H}(\mathrm{ads}) \rightarrow \mathrm{SiHCl}_{2}$ (ads) & -153 & 192 & 186 & 506 & $4 \times 10^{-9}$ \\
\hline R34 & $\mathrm{SiH}(\mathrm{g})+*(\mathrm{ads}) \rightarrow \mathrm{SiH}(\mathrm{ads})$ & -341 & - & -51 & - & - \\
\hline R35 & $\mathrm{SiH}_{2}(\mathrm{~g})+*(\mathrm{ads}) \rightarrow \mathrm{SiH}_{2}(\mathrm{ads})$ & -301 & - & -1 & - & - \\
\hline R36 & $\mathrm{SiCl}(\mathrm{g})+*(\mathrm{ads}) \rightarrow \mathrm{SiCl}(\mathrm{ads})$ & -338 & - & -25 & - & - \\
\hline R37 & $\mathrm{SiHCl}(\mathrm{g})+*(\mathrm{ads}) \rightarrow \mathrm{SiHCl}(\mathrm{ads})$ & -267 & - & 66 & - & - \\
\hline R38 & $\mathrm{SiCl}_{2}(\mathrm{~g})+*(\mathrm{ads}) \rightarrow \mathrm{SiCl}_{2}(\mathrm{ads})$ & -212 & . & 129 & - & \\
\hline
\end{tabular}

a) Energies and free energies of reaction, ${ }^{\text {b) }}$ energies and free energies of activation, ${ }^{\text {c) }}$ sticking coefficients. 
Table 6 The adsorption and desorption rate constants at $1600{ }^{\circ} \mathrm{C}$ of $\mathrm{SiH}, \mathrm{SiH}_{2}, \mathrm{SiCl}, \mathrm{SiHCl}$ and $\mathrm{SiCl}_{2}$ on $\mathrm{H}(\mathrm{ads})$ on the $\mathrm{C}$ face of $4 \mathrm{H}-\mathrm{SiC}$.

\begin{tabular}{|l|l|c|c|}
\hline & & $\begin{array}{c}\text { Adsorption rate } \\
\text { constant }\end{array}$ & $\begin{array}{c}\text { Desorption rate } \\
\text { constant }\end{array}$ \\
\hline R29 & $\mathrm{SiH}(\mathrm{g})+\mathrm{H}($ ads $) \rightarrow \mathrm{SiH}_{2}$ (ads) & 2 & $2 \times 10^{7}$ \\
\hline $\mathrm{R} 30$ & $\mathrm{SiH}_{2}(\mathrm{~g})+\mathrm{H}(\mathrm{ads}) \rightarrow \mathrm{SiH}_{3}$ (ads) & $5 \times 10^{-2}$ & $2 \times 10^{5}$ \\
\hline $\mathrm{R} 31$ & $\mathrm{SiCl}(\mathrm{g})+\mathrm{H}($ ads $) \rightarrow \mathrm{SiHCl}_{(\mathrm{ads})}$ & $1 \times 10^{-1}$ & $8 \times 10^{7}$ \\
\hline $\mathrm{R} 32$ & $\mathrm{SiHCl}(\mathrm{g})+\mathrm{H}(\mathrm{ads}) \rightarrow \mathrm{SiH}_{2} \mathrm{Cl}(\mathrm{ads})$ & $4 \times 10^{-4}$ & $2 \times 10^{5}$ \\
\hline $\mathrm{R} 33$ & $\mathrm{SiCl}_{2}(\mathrm{~g})+\mathrm{H}(\mathrm{ads}) \rightarrow \mathrm{SiHCl}_{2}$ (ads) & $2 \times 10^{-6}$ & $5 \times 10^{4}$ \\
\hline
\end{tabular}

a) The adsorption rate constants, $R_{a d s} / p \gamma_{g} \Theta_{s}$, are calculated using Eq. 5-8. Here, the adsorption rate $\left(R_{a d s}\right)$ is in molecule per site per second. The total pressure $(p)$ is in pascal. The gaseous molar fraction $\left(\gamma_{g}\right)$ and the surface fraction $\left(\Theta_{s}\right)$ are unitless. The surface area per site of $\mathrm{H}(\mathrm{ads})$ is assumed equal to $8.178 \times 10^{-20} \mathrm{~m}^{2}$ which is the area per one lattice site on the C-face of $4 \mathrm{H}-\mathrm{SiC}$.

b) The desorption rate constants, $R_{d e} / \Theta_{s}$, are calculated using Eq. 9-10. Here, the desorption rate $\left(R_{d e}\right)$ is in molecule per site per second. The surface fraction $\left(\Theta_{S}\right)$ is unitless.

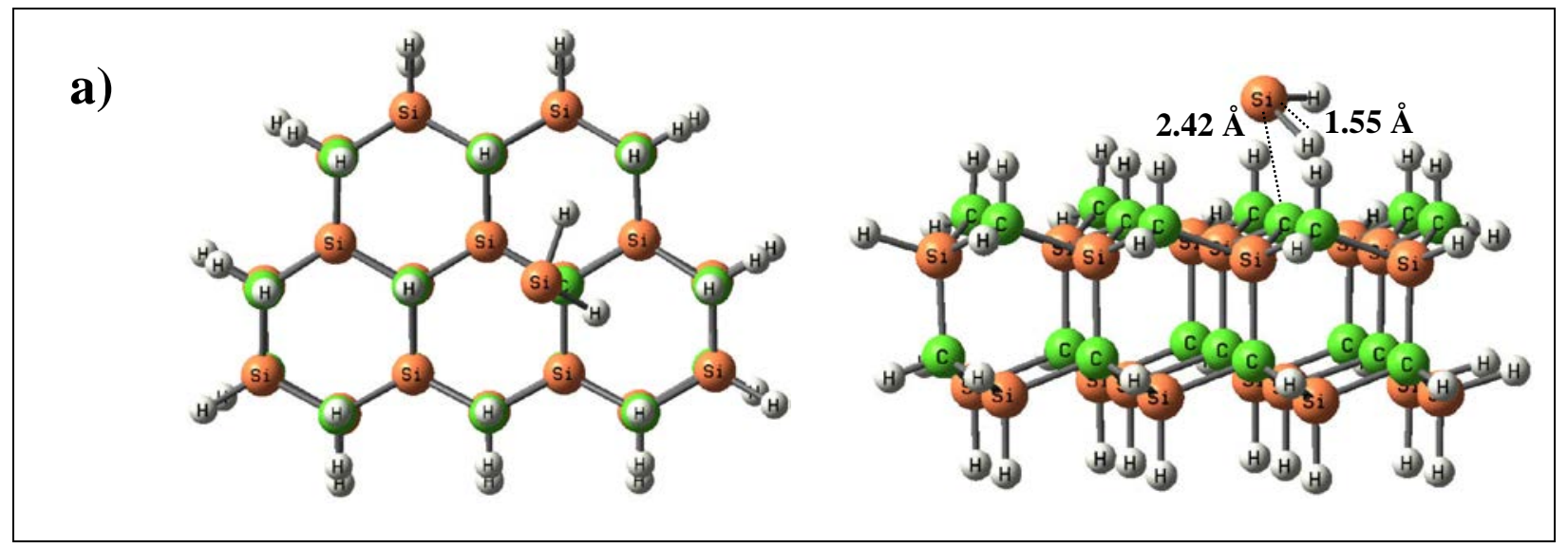



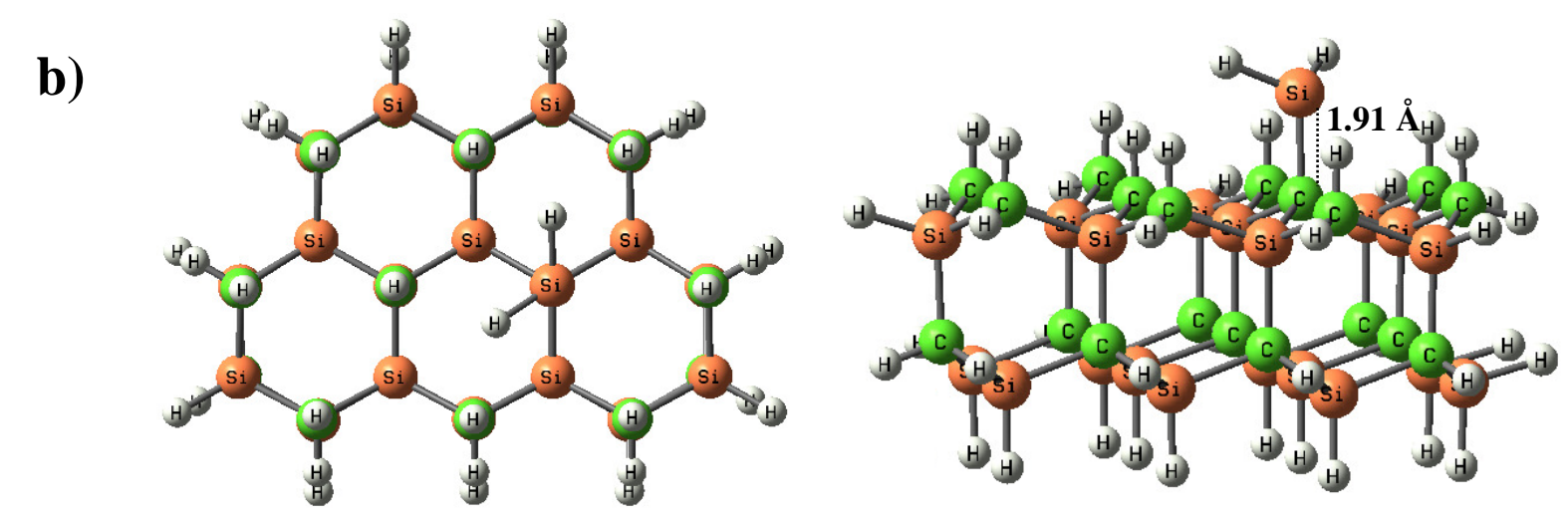

Figure 9. Top view and side view of a) the transition state and b) the product of $\mathrm{SiH}$ adsorption on $\mathrm{H}$ (ads) on the C-face of $4 \mathrm{H}-\mathrm{SiC}$.

3 Adsorptions of $\operatorname{SiH}_{x} F_{y}, \operatorname{SiH}_{\mathbf{x}} \mathbf{B r}_{\mathbf{y}}$ and $\mathrm{Si}$ atoms. The Gibbs free energies $\left(\Delta_{R} G^{\circ}\right)$ of adsorptions of $\mathrm{SiH}_{\mathrm{x}} \mathrm{F}_{\mathrm{y}}, \mathrm{SiH}_{\mathrm{x}} \mathrm{Br}_{\mathrm{y}}$ and $\mathrm{Si}$ atoms on both the $\mathrm{Si}$ face and the $\mathrm{C}$ face of $4 \mathrm{H}-\mathrm{SiC}$ are shown in Table 7 and 8. Similar to the previous sections, adsorptions are more favorable on a surface site with the presence of a dangling bond, i.e. $\mathrm{CH}_{2}$ (ads) and *(ads).

Adsorptions of $\mathrm{Si}$ atoms are shown to be the most thermodynamically favorable among all the $\mathrm{Si}$ species in the study. On the Si face, the Gibbs free energies $\left(\Delta_{R} G^{\circ}\right)$ of $\mathrm{Si}$ atom adsorptions on $\mathrm{CH}_{3}$ (ads) and $\mathrm{CH}_{2}$ (ads) are 24 and $-48 \mathrm{~kJ} / \mathrm{mol}$ at $1600{ }^{\circ} \mathrm{C}$, which are the lowest $\Delta_{R} G^{\circ}$ among the set. Similarly, on the $\mathrm{C}$ face, $\Delta_{R} G^{\circ}$ of $\mathrm{Si}$ atom adsorptions on $\mathrm{H}(\mathrm{ads})$ and *(ads) are also smallest among the set, with $\Delta_{R} G^{\circ}$ of -7 and $-109 \mathrm{~kJ} / \mathrm{mol}$ at $1600{ }^{\circ} \mathrm{C}$. Due to the change in the spin states, these reactions are spin-forbidden and the calculation of the reaction rates is beyond the scope of this study.

For the halide systems, the Gibbs free energies $\left(\Delta_{R} G^{\circ}\right)$ from smallest to largest are observed in the adsorptions of $\mathrm{SiX}, \mathrm{SiHX}$ and $\mathrm{SiX}_{2}$, for $\mathrm{X}$ being the halides. This is similar to what we previously 
observed in the adsorptions of the $\mathrm{Cl}$ chemistry. As a result, we propose that $\mathrm{SiX}$ (for $\mathrm{X}$ being $\mathrm{F}$, $\mathrm{Cl}$ and $\mathrm{Br}$ ) are the major growth contributors to $\mathrm{SiC}$ among the $\mathrm{SiH}_{\mathrm{x}} \mathrm{X}_{\mathrm{y}}$ species.

Table 7 The energies $(0 \mathrm{~K})$ and standard Gibbs free energies $\left(1600^{\circ} \mathrm{C}\right)$ of the adsorption processes of $\mathrm{Si}$ atoms, $\mathrm{SiF}, \mathrm{SiHF}, \mathrm{SiF}_{2}, \mathrm{SiBr}, \mathrm{SiHBr}$ and $\mathrm{SiBr}_{2}$ on $\mathrm{CH}_{3}$ (ads) and $\mathrm{CH}_{2}$ (ads) pre-deposited on the Si face of $4 \mathrm{H}-\mathrm{SiC}$. The (free) energies are presented in the unit of $\mathrm{kJ} / \mathrm{mol}$, calculated with respect to the energy of the reactant state at asymptote condition.

\begin{tabular}{|c|c|c|c|}
\hline & & $\begin{array}{c}\Delta_{R} E^{\circ \mathrm{a})} \\
(0 \mathrm{~K})\end{array}$ & $\begin{array}{c}\Delta_{R} G^{\circ \mathrm{a})} \\
\left(1600^{\circ} \mathrm{C}\right)\end{array}$ \\
\hline $\mathrm{R} 40$ & ${ }^{3} \mathrm{Si}(\mathrm{g})+\mathrm{CH}_{3}$ (ads) $\rightarrow \mathrm{SiH}-\mathrm{CH}_{2}$ (ads) & -217 & 24 \\
\hline $\mathrm{R} 41$ & $\mathrm{SiF}(\mathrm{g})+\mathrm{CH}_{3}(\mathrm{ads}) \rightarrow \mathrm{SiHF}-\mathrm{CH}_{2}$ (ads) & -127 & 139 \\
\hline $\mathrm{R} 42$ & $\mathrm{SiHF}(\mathrm{g})+\mathrm{CH}_{3}(\mathrm{ads}) \rightarrow \mathrm{SiH}_{2} \mathrm{~F}-\mathrm{CH}_{2}$ (ads) & -192 & 120 \\
\hline $\mathrm{R} 43$ & $\mathrm{SiF}_{2}(\mathrm{~g})+\mathrm{CH}_{3}(\mathrm{ads}) \rightarrow \mathrm{SiHF}_{2}-\mathrm{CH}_{2}$ (ads) & -138 & 167 \\
\hline $\mathrm{R} 44$ & $\mathrm{SiBr}(\mathrm{g})+\mathrm{CH}_{3}(\mathrm{ads}) \rightarrow \mathrm{SiHBr}-\mathrm{CH}_{2}$ (ads) & -120 & 135 \\
\hline $\mathrm{R} 45$ & $\mathrm{SiHBr}(\mathrm{g})+\mathrm{CH}_{3}(\mathrm{ads}) \rightarrow \mathrm{SiH}_{2} \mathrm{Br}-\mathrm{CH}_{2}$ (ads) & -180 & 133 \\
\hline $\mathrm{R} 46$ & $\mathrm{SiBr}_{2}(\mathrm{~g})+\mathrm{CH}_{3}(\mathrm{ads}) \rightarrow \mathrm{SiHBr}_{2}-\mathrm{CH}_{2}(\mathrm{ads})$ & -130 & 184 \\
\hline $\mathrm{R} 47$ & ${ }^{3} \mathrm{Si}(\mathrm{g})+\mathrm{CH}_{2}$ (ads) $\rightarrow \mathrm{Si}-\mathrm{CH}_{2}$ (ads) & -320 & -48 \\
\hline $\mathrm{R} 48$ & $\mathrm{SiF}(\mathrm{g})+\mathrm{CH}_{2}(\mathrm{ads}) \rightarrow \mathrm{SiF}-\mathrm{CH}_{2}$ (ads) & -316 & 19 \\
\hline $\mathrm{R} 49$ & $\mathrm{SiHF}(\mathrm{g})+\mathrm{CH}_{2}(\mathrm{ads}) \rightarrow \mathrm{SiHF}-\mathrm{CH}_{2}$ (ads) & -225 & 110 \\
\hline $\mathrm{R} 50$ & $\mathrm{SiF}_{2}(\mathrm{~g})+\mathrm{CH}_{2}(\mathrm{ads}) \rightarrow \mathrm{SiF}_{2}-\mathrm{CH}_{2}$ (ads) & -163 & 162 \\
\hline R51 & $\mathrm{SiBr}(\mathrm{g})+\mathrm{CH}_{2}(\mathrm{ads}) \rightarrow \mathrm{SiBr}-\mathrm{CH}_{2}$ (ads) & -304 & 35 \\
\hline R52 & $\mathrm{SiHBr}(\mathrm{g})+\mathrm{CH}_{2}(\mathrm{ads}) \rightarrow \mathrm{SiHBr}-\mathrm{CH}_{2}$ (ads) & -224 & 101 \\
\hline $\mathrm{R} 53$ & $\mathrm{SiBr}_{2}(\mathrm{~g})+\mathrm{CH}_{2}(\mathrm{ads}) \rightarrow \mathrm{SiBr}_{2}-\mathrm{CH}_{2}$ (ads) & -189 & 139 \\
\hline
\end{tabular}

a) Energies and free energies of reaction. 
Table 8 The energies $(0 \mathrm{~K})$ and standard Gibbs free energies $\left(1600^{\circ} \mathrm{C}\right)$ of the adsorption processes of Si atoms, $\mathrm{SiF}, \mathrm{SiHF}, \mathrm{SiF}_{2}$, $\mathrm{SiBr}, \mathrm{SiHBr}$ and $\mathrm{SiBr}_{2}$ on $\mathrm{H}(\mathrm{ads})$ and $*(\mathrm{ads})$ on the $\mathrm{C}$ face of $4 \mathrm{H}-\mathrm{SiC}$. The (free) energies are presented in the unit of $\mathrm{kJ} / \mathrm{mol}$, calculated with respect to the energy of the reactant state at asymptote condition.

\begin{tabular}{|c|c|c|c|}
\hline & & $\begin{array}{c}\Delta_{R} E^{\circ \mathrm{a})} \\
(0 \mathrm{~K})\end{array}$ & $\begin{array}{c}\Delta_{R} G^{\circ \text { a })} \\
\left(1600^{\circ} \mathrm{C}\right)\end{array}$ \\
\hline R54 & ${ }^{3} \mathrm{Si}(\mathrm{g})+\mathrm{H}(\mathrm{ads}) \rightarrow \mathrm{SiH}(\mathrm{ads})$ & -222 & -7 \\
\hline R55 & $\mathrm{SiF}(\mathrm{g})+\mathrm{H}(\mathrm{ads}) \rightarrow \mathrm{SiHF}(\mathrm{ads})$ & -161 & 107 \\
\hline R56 & $\mathrm{SiHF}(\mathrm{g})+\mathrm{H}(\mathrm{ads}) \rightarrow \mathrm{SiH}_{2} \mathrm{~F}(\mathrm{ads})$ & -225 & 100 \\
\hline R57 & $\mathrm{SiF}_{2}(\mathrm{~g})+\mathrm{H}(\mathrm{ads}) \rightarrow \mathrm{SiHF}_{2}$ (ads) & -175 & 156 \\
\hline R58 & $\mathrm{SiBr}(\mathrm{g})+\mathrm{H}(\mathrm{ads}) \rightarrow \operatorname{SiHBr}(\mathrm{ads})$ & -148 & 135 \\
\hline R59 & $\mathrm{SiHBr}(\mathrm{g})+\mathrm{H}(\mathrm{ads}) \rightarrow \mathrm{SiH}_{2} \mathrm{Br}(\mathrm{ads})$ & -204 & 134 \\
\hline R60 & $\mathrm{SiBr}_{2}(\mathrm{~g})+\mathrm{H}(\mathrm{ads}) \rightarrow \mathrm{SiHBr}_{2}$ (ads) & -142 & 194 \\
\hline R61 & ${ }^{3} \mathrm{Si}(\mathrm{g})+*(\mathrm{ads}) \rightarrow \mathrm{Si}(\mathrm{ads})$ & -351 & -109 \\
\hline R62 & $\operatorname{SiF}(\mathrm{g})+*(\mathrm{ads}) \rightarrow \operatorname{SiF}(\mathrm{ads})$ & -355 & -44 \\
\hline R63 & $\mathrm{SiHF}(\mathrm{g})+*(\mathrm{ads}) \rightarrow \operatorname{SiHF}(\mathrm{ads})$ & -275 & 44 \\
\hline R64 & $\mathrm{SiF}_{2}(\mathrm{~g})+*(\mathrm{ads}) \rightarrow \mathrm{SiF}_{2}(\mathrm{ads})$ & -215 & 108 \\
\hline R65 & $\operatorname{SiBr}(\mathrm{g})+*(\mathrm{ads}) \rightarrow \operatorname{SiBr}(\mathrm{ads})$ & -335 & -10 \\
\hline R66 & $\operatorname{SiHBr}(\mathrm{g})+*(\mathrm{ads}) \rightarrow \operatorname{SiHBr}(\mathrm{ads})$ & -268 & 67 \\
\hline R67 & $\mathrm{SiBr}_{2}(\mathrm{~g})+*(\mathrm{ads}) \rightarrow \mathrm{SiBr}_{2}$ (ads) & -211 & 133 \\
\hline
\end{tabular}

\section{Summary and Conclusion}

The density functional theory (B3LYP and M06-2X) and transition state theory are used to study adsorption processes of active $\mathrm{Si}$ species on the $\mathrm{Si}$ face and the $\mathrm{C}$ face of $4 \mathrm{H}-\mathrm{SiC}$. On the Si face, 
we show that adsorptions of $\mathrm{SiCl}, \mathrm{SiCl}_{2}, \mathrm{SiHCl}, \mathrm{SiH}$ and $\mathrm{SiH}_{2}$ occurs more likely on a methylene site, $\mathrm{CH}_{2}$ (ads). The processes are shown to occur without the presence of transition states and thus relatively large sticking probabilities should be expected. The $\Delta_{R} G^{\circ}$ from smallest to largest are $\mathrm{SiH}>\mathrm{SiCl}>\mathrm{SiH}_{2}>\mathrm{SiHCl}>\mathrm{SiCl}_{2}$. Adsorptions on a methyl site, $\mathrm{CH}_{3}$ (ads), and on an ethylene site, $\mathrm{C}_{2} \mathrm{H}_{4}(\mathrm{ads})$, both occur with relatively large activation barriers at the CVD process condition resulting in small sticking probabilities of all Si species considered. The adsorptions on $\mathrm{CH}_{2}$ (ads), $\mathrm{CH}_{3}$ (ads) as well as $\mathrm{C}_{2} \mathrm{H}_{4}$ (ads) are all shown to be thermodynamically less favorable than their reverse, i.e. desorptions. The adsorbed products are shown to be stabilized by reacting with adjacent methyl sites and forming a larger cluster. These subsequent processes happen with rates that are fast enough to compete with desorption processes. On the $\mathrm{C}$ face, the adsorptions likely occur on a surface site terminated by a dangling bond, *(ads), which are shown to occur without the presence of transition states and produce stable products. The $\Delta_{R} G^{\circ}$ from smallest to largest are $\mathrm{SiH}>\mathrm{SiCl}>\mathrm{SiH}_{2}>\mathrm{SiHCl}>\mathrm{SiCl}_{2}$. Lastly, we present the Gibbs free energies of adsorptions of $\mathrm{Si}$ atoms, $\mathrm{SiX}, \mathrm{SiX}_{2}, \mathrm{SiHX}$, for $\mathrm{X}$ being $\mathrm{F}$ and $\mathrm{Br}$. Again, it is observed that adsorptions on the Si face occurs most likely on a methylene site, $\mathrm{CH}_{2}$ (ads), while adsorptions on the $\mathrm{C}$ face occur on a surface site terminated by a dangling bond, *(ads). Adsorptions of Si atoms are shown to be the most thermodynamically favorable among all the species in the study. Among the halidecontaining species, the Gibbs free energies $\left(\Delta_{R} G^{\circ}\right)$ from smallest to largest are observed in the adsorptions of $\mathrm{SiX}, \mathrm{SiHX}$ and $\mathrm{SiX}_{2}$, for $\mathrm{X}$ being the halides. From the results obtained in this study we conclude that the major Si contributors in the SiC-CVD process are Si atoms, SiX (for X being the halide) and $\mathrm{SiH}$. This is unlike $\mathrm{Si}-\mathrm{CVD}$ processes in which $\mathrm{SiH}_{2}$ was predicted to be the most important species contributing to $\mathrm{Si}$ deposition ${ }^{26,27}$. The results also imply that $\mathrm{SiX}_{2}$ is not a major contributor to $\mathrm{SiC}$ growth, in contrast to previous assumptions. 


\section{Supporting Information}

Gibbs free energies, sticking coefficients, rate constants at the temperature range of $298-2500 \mathrm{~K}$ and molecular coordinates. This material is available free of charge via the internet at http://pubs.acs.org.

\section{Corresponding Authors}

*Emails: pitsu@ifm.liu.se and lars@ifm.liu.se.

\section{Acknowledgment}

The authors acknowledge financial support from the Swedish Foundation for Strategic Research, from the Swedish Government Strategic Research Area in Materials Science on Functional Materials at Linköping University (Faculty Grant SFO Mat LiU No 2009 00971), and from the Swedish Research Council (VR Grant No. 2016-05137_4). Supercomputer resources were provided by the Swedish National Infrastructure for Computing (SNIC) and the National Supercomputer Centre (NSC), Linköping University.

\section{References}

(1) Kimoto, T. Material Science and Device Physics in SiC Technology for High-Voltage Power Devices. Jpn. J. Appl. Phys. 2015, 54 (4), 040103.

(2) Millan, J.; Godignon, P.; Perpina, X.; Perez-Tomas, A.; Rebollo, J. A Survey of Wide Bandgap Power Semiconductor Devices. IEEE Trans. Power Electron. 2014, 29 (5), 21552163.

(3) Fujita, S. Wide-Bandgap Semiconductor Materials: For Their Full Bloom. Jpn. J. Appl. Phys. 2015, 54 (3), 030101.

(4) Wright, N. G.; Horsfall, A. B.; Vassilevski, K. Prospects for SiC Electronics and Sensors. Mater. Today 2008, 11 (1-2), 16-21.

(5) Oliveros, A.; Guiseppi-Elie, A.; Saddow, S. E. Silicon Carbide: A Versatile Material for Biosensor Applications. Biomed. Microdevices 2013, 15 (2), 353-368.

(6) Kimoto, T. Bulk and Epitaxial Growth of Silicon Carbide. Prog. Cryst. Growth Charact. Mater. 2016, 62 (2), 329-351. 
(7) Pedersen, H.; Leone, S.; Kordina, O.; Henry, A.; Nishizawa, S.; Koshka, Y.; Janzén, E. Chloride-Based CVD Growth of Silicon Carbide for Electronic Applications. Chem. Rev. 2012, 112 (4), 2434-2453.

(8) Yazdanfar, M.; Danielsson, Ö.; Kalered, E.; Sukkaew, P.; Kordina, O.; Nilsson, D.; Ivanov, I. G.; Ojamäe, L.; Janzén, E.; Pedersen, H. Brominated Chemistry for Chemical Vapor Deposition of Electronic Grade SiC. Chem. Mater. 2015, 27 (3), 793-801.

(9) Rana, T.; Chandrashekhar, M. V. S.; Sudarshan, T. S. Elimination of Silicon Gas Phase Nucleation Using Tetrafluorosilane (SiF4) Precursor for High Quality Thick Silicon Carbide (SiC) Homoepitaxy. Phys. Status Solidi A 2012, 209 (12), 2455-2462.

(10) Stenberg, P.; Sukkaew, P.; Farkas, I.; Kordina, O.; Janzén, E.; Ojamäe, L.; Danielsson, Ö.; Pedersen, H. Silicon Chemistry in Fluorinated Chemical Vapor Deposition of Silicon Carbide. J. Phys. Chem. C 2017, 121 (5), 2711-2720.

(11) Kalered, E.; Pedersen, H.; Janzén, E.; Ojamäe, L. Adsorption and Surface Diffusion of Silicon Growth Species in Silicon Carbide Chemical Vapour Deposition Processes Studied by Quantum-Chemical Computations. Theor. Chem. Acc. 2013, 132 (12), 1403.

(12) Sukkaew, P.; Danielsson, Ö.; Kordina, O.; Janzén, E.; Ojamäe, L. Ab Initio Study of Growth Mechanism of 4H-SiC: Adsorption and Surface Reaction of C2H2, C2H4, CH4, and CH3. J. Phys. Chem. C 2017, 121 (2), 1249-1256.

(13) Becke, A. D. Density-functional Thermochemistry. III. The Role of Exact Exchange. J. Chem. Phys. 1993, 98 (7), 5648-5652.

(14) Lee, C.; Yang, W.; Parr, R. G. Development of the Colle-Salvetti Correlation-Energy Formula into a Functional of the Electron Density. Phys. Rev. B 1988, 37 (2), 785-789.

(15) Dunning, T. H.; Hay, P. J. Gaussian Basis Sets for Molecular Calculations. In Methods of Electronic Structure Theory; Schaefer, H. F., Ed.; Springer US: Boston, MA, 1977; pp 127.

(16) Wadt, W. R.; Hay, P. J. Ab Initio Effective Core Potentials for Molecular Calculations. Potentials for Main Group Elements Na to Bi. J. Chem. Phys. 1985, 82 (1), 284-298.

(17) Grimme, S.; Antony, J.; Ehrlich, S.; Krieg, H. A Consistent and Accurate Ab Initio Parametrization of Density Functional Dispersion Correction (DFT-D) for the 94 Elements H-Pu. J. Chem. Phys. 2010, 132 (15), 154104.

(18) Zhao, Y.; Truhlar, D. G. The M06 Suite of Density Functionals for Main Group Thermochemistry, Thermochemical Kinetics, Noncovalent Interactions, Excited States, and Transition Elements: Two New Functionals and Systematic Testing of Four M06-Class Functionals and 12 Other Functionals. Theor. Chem. Acc. 2008, 120 (1), 215-241.

(19) Dunning, T. H. Gaussian Basis Sets for Use in Correlated Molecular Calculations. I. The Atoms Boron through Neon and Hydrogen. J. Chem. Phys. 1989, 90 (2), 1007-1023.

(20) Frisch, M. J.; Trucks, G. W.; Schlegel, H. B.; Scuseria, G. E.; Robb, M. A.; Cheeseman, J. R.; Scalmani, G.; Barone, V.; Mennucci, B.; Petersson, G. A.; et al. Gaussian 09; Gaussian, Inc.: Wallingford, CT, USA, 2009.

(21) Truhlar, D. G.; Garrett, B. C.; Klippenstein, S. J. Current Status of Transition-State Theory. J. Phys. Chem. 1996, 100 (31), 12771-12800.

(22) Truhlar, D. G.; Garrett, B. C. Variational Transition-State Theory. Acc. Chem. Res. 1980, 13 (12), 440-448.

(23) Reuter, K.; Scheffler, M. First-Principles Kinetic Monte Carlo Simulations for Heterogeneous Catalysis: Application to the CO Oxidation at RuO2(110). Phys. Rev. B 2006, 73 (4), 045433. 
(24) Silicon Carbide (SiC), Lattice Parameters, Thermal Expansion. In Group IV Elements, IVIV and III-V Compounds. Part b - Electronic, Transport, Optical and Other Properties; Madelung, O., Rössler, U., Schulz, M., Eds.; Springer Berlin Heidelberg: Berlin, Heidelberg, 2002; pp 1-11.

(25) Danielsson, Ö.; Sukkaew, P.; Ojamäe, L.; Kordina, O.; Janzén, E. Shortcomings of CVD Modeling of SiC Today. Theor. Chem. Acc. 2013, 132 (11), 1398.

(26) Coltrin, M. E.; Kee, R. J.; Miller, J. A. A Mathematical Model of the Coupled Fluid Mechanics and Chemical Kinetics in a Chemical Vapor Deposition Reactor. J. Electrochem. Soc. 1984, 131 (2), 425-434.

(27) Coltrin, M. E.; Kee, R. J.; Evans, G. H. A Mathematical Model of the Fluid Mechanics and Gas-Phase Chemistry in a Rotating Disk Chemical Vapor Deposition Reactor. J. Electrochem. Soc. 1989, 136 (3), 819-829.

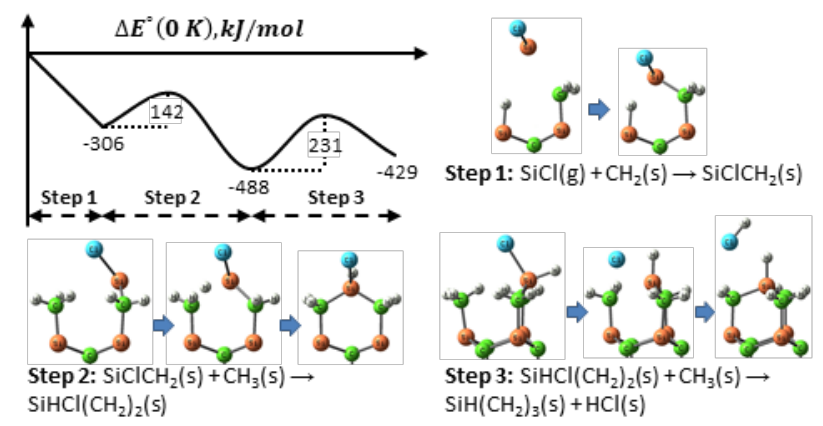




\section{Supporting Information for}

Growth Mechanism of SiC CVD - Adsorption and Surface Reactions of Active Si Species

Pitsiri Sukkaew*, Emil Kalered, Erik Janzén, Olof Kordina, Örjan Danielsson and Lars

Ojamäe*

Department of Physics, Chemistry and Biology, Linköping University, SE-581 83 Linköping, Sweden

*Emails: pitsu@ifm.liu.se and lars@ifm.liu.se. 
Table S1 Gibbs free energies of reaction $\left(\Delta G^{\circ}\right)$ in $\mathrm{kJ} / \mathrm{mol}$ at the temperature range of 298 $-2500 \mathrm{~K}$.

$$
\Delta G_{R}^{\circ}=a_{1} T^{4}+a_{2} T^{3}+a_{3} T^{2}+a_{4} T+a_{5} \text { for temperature }(\mathrm{T})=298-2500 \mathrm{~K} \text {. }
$$

\begin{tabular}{|c|c|c|c|c|c|c|}
\hline & & $a_{1}$ & $a_{2}$ & $a_{3}$ & $a_{4}$ & $a_{5}$ \\
\hline $\mathrm{R} 1$ & $\begin{array}{l}\mathrm{SiH}(\mathrm{g})+\mathrm{CH}_{3}(\mathrm{ads}) \rightarrow \\
\mathrm{SiH}_{2}-\mathrm{CH}_{2} \text { (ads) }\end{array}$ & $-2.87 \mathrm{E}-13$ & $2.95 \mathrm{E}-09$ & $-1.42 \mathrm{E}-05$ & $1.54 \mathrm{E}-01$ & $-1.61 E+02$ \\
\hline $\mathrm{R} 2$ & $\begin{array}{l}\mathrm{SiH}_{2}(\mathrm{~g})+\mathrm{CH}_{3}(\mathrm{ads}) \rightarrow \\
\mathrm{SiH}_{3}-\mathrm{CH}_{2} \text { (ads) }\end{array}$ & $-1.37 \mathrm{E}-13$ & 2.03E-09 & $-1.31 \mathrm{E}-05$ & $1.79 \mathrm{E}-01$ & $-2.09 E+02$ \\
\hline R3 & $\begin{array}{l}\mathrm{SiCl}(\mathrm{g})+\mathrm{CH}_{3}(\mathrm{ads}) \rightarrow \\
\mathrm{SiHCl}-\mathrm{CH}_{2} \text { (ads) }\end{array}$ & $-4.63 E-13$ & $4.20 \mathrm{E}-09$ & $-1.76 \mathrm{E}-05$ & 1.67E-01 & $-1.27 \mathrm{E}+02$ \\
\hline $\mathrm{R} 4$ & $\begin{array}{l}\mathrm{SiHCl}(\mathrm{g})+\mathrm{CH}_{3}(\mathrm{ads}) \rightarrow \\
\mathrm{SiH}_{2} \mathrm{Cl}-\mathrm{CH}_{2} \text { (ads) }\end{array}$ & $-3.29 E-13$ & $3.35 \mathrm{E}-09$ & $-1.65 E-05$ & $1.93 \mathrm{E}-01$ & $-1.89 \mathrm{E}+02$ \\
\hline R5 & $\begin{array}{l}\mathrm{SiCl}_{2}(\mathrm{~g})+\mathrm{CH}_{3}(\mathrm{ads}) \rightarrow \\
\mathrm{SiHCl}_{2}-\mathrm{CH}_{2} \text { (ads) }\end{array}$ & $-5.67 E-13$ & 5.03E-09 & $-2.10 \mathrm{E}-05$ & $1.93 \mathrm{E}-01$ & $-1.36 \mathrm{E}+02$ \\
\hline R6 & $\begin{array}{l}\mathrm{SiH}(\mathrm{g})+\mathrm{CH}_{2} \text { (ads) } \rightarrow \\
\mathrm{SiH}-\mathrm{CH}_{2} \text { (ads) }\end{array}$ & $5.36 \mathrm{E}-13$ & $-2.93 \mathrm{E}-09$ & $1.84 \mathrm{E}-06$ & $1.86 \mathrm{E}-01$ & $-3.28 \mathrm{E}+02$ \\
\hline R7 & $\begin{array}{c}\mathrm{SiH}_{2}(\mathrm{~g})+\mathrm{CH}_{2} \text { (ads) } \rightarrow \\
\mathrm{SiH}_{2}-\mathrm{CH}_{2} \text { (ads) }\end{array}$ & $3.17 E-13$ & $-1.36 \mathrm{E}-09$ & $-3.24 \mathrm{E}-06$ & 1.79E-01 & $-2.54 \mathrm{E}+02$ \\
\hline R8 & $\begin{array}{l}\mathrm{SiCl}(\mathrm{g})+\mathrm{CH}_{2} \text { (ads) } \rightarrow \\
\mathrm{SiCl}-\mathrm{CH}_{2} \text { (ads) }\end{array}$ & $2.12 \mathrm{E}-13$ & $-7.33 E-10$ & $-3.66 \mathrm{E}-06$ & $1.93 \mathrm{E}-01$ & $-3.10 E+02$ \\
\hline R9 & $\begin{array}{l}\mathrm{SiHCl}(\mathrm{g})+\mathrm{CH}_{2}(\mathrm{ads}) \rightarrow \\
\mathrm{SiHCl}-\mathrm{CH}_{2} \text { (ads) }\end{array}$ & $2.58 \mathrm{E}-13$ & $-9.36 \mathrm{E}-10$ & $-4.42 \mathrm{E}-06$ & $1.94 \mathrm{E}-01$ & $-2.31 E+02$ \\
\hline R10 & $\begin{array}{l}\mathrm{SiCl}_{2}(\mathrm{~g})+\mathrm{CH}_{2}(\mathrm{ads}) \rightarrow \\
\mathrm{SiCl}_{2}-\mathrm{CH}_{2} \text { (ads) }\end{array}$ & $-5.17 \mathrm{E}-14$ & $1.23 \mathrm{E}-09$ & $-1.01 \mathrm{E}-05$ & $1.82 \mathrm{E}-01$ & $-1.85 \mathrm{E}+02$ \\
\hline R11 & $\begin{array}{l}\mathrm{SiH}(\mathrm{g})+\mathrm{C}_{2} \mathrm{H}_{4} \text { (ads) } \rightarrow \\
\mathrm{SiH}-\left(\mathrm{CH}_{2}\right)_{2} \text { (ads) }\end{array}$ & $-3.25 E-13$ & 2.92E-09 & $-1.28 \mathrm{E}-05$ & 1.60E-01 & $-2.80 \mathrm{E}+02$ \\
\hline R12 & $\begin{array}{l}\mathrm{SiH}_{2}(\mathrm{~g})+\mathrm{C}_{2} \mathrm{H}_{4}(\mathrm{ads}) \rightarrow \\
\mathrm{SiH}_{2}-\left(\mathrm{CH}_{2}\right)_{2} \text { (ads) }\end{array}$ & $-2.19 \mathrm{E}-13$ & $2.35 \mathrm{E}-09$ & $-1.28 \mathrm{E}-05$ & $1.80 \mathrm{E}-01$ & $-3.33 E+02$ \\
\hline R13 & $\begin{array}{l}\mathrm{SiCl}(\mathrm{g})+\mathrm{C}_{2} \mathrm{H}_{4} \text { (ads) } \rightarrow \\
\mathrm{SiCl}-\left(\mathrm{CH}_{2}\right)_{2} \text { (ads) }\end{array}$ & $-6.34 \mathrm{E}-13$ & 5.07E-09 & $-1.83 E-05$ & $1.72 \mathrm{E}-01$ & $-2.47 E+02$ \\
\hline R14 & $\begin{array}{l}\mathrm{SiHCl}(\mathrm{g})+\mathrm{C}_{2} \mathrm{H}_{4} \text { (ads) } \rightarrow \\
\mathrm{SiHCl}-\left(\mathrm{CH}_{2}\right)_{2} \text { (ads) }\end{array}$ & $-5.08 \mathrm{E}-13$ & 4.35E-09 & $-1.79 E-05$ & $1.94 \mathrm{E}-01$ & $-3.15 E+02$ \\
\hline R15 & $\begin{array}{l}\mathrm{SiCl}_{2}(\mathrm{~g})+\mathrm{C}_{2} \mathrm{H}_{4}(\mathrm{ads}) \rightarrow \\
\mathrm{SiCl}_{2}-\left(\mathrm{CH}_{2}\right)_{2} \text { (ads) }\end{array}$ & $-7.43 E-13$ & 5.97E-09 & $-2.21 E-05$ & $1.98 \mathrm{E}-01$ & $-2.75 E+02$ \\
\hline R17 & $\begin{array}{l}\mathrm{C}_{2} \mathrm{H}_{4} \text { (ads) }+\mathrm{H}(\mathrm{g}) \rightarrow \\
\mathrm{CH}_{2} \text { (ads) }+\mathrm{CH}_{3} \text { (ads) }\end{array}$ & $-1.55 E-13$ & $7.55 \mathrm{E}-10$ & $-1.21 \mathrm{E}-06$ & $7.50 \mathrm{E}-02$ & $-1.38 \mathrm{E}+02$ \\
\hline R18 & $\begin{array}{l}\mathrm{SiH}-\mathrm{CH}_{2} \text { (ads) }+ \\
\mathrm{CH}_{3}(\mathrm{ads}) \rightarrow \mathrm{SiH}_{2}- \\
\left(\mathrm{CH}_{2}\right)_{2} \text { (ads) }\end{array}$ & $3.94 \mathrm{E}-13$ & $-2.44 \mathrm{E}-09$ & $5.02 \mathrm{E}-06$ & $3.13 E-02$ & $-2.23 E+02$ \\
\hline
\end{tabular}




\begin{tabular}{|c|c|c|c|c|c|c|}
\hline R19 & $\begin{array}{l}\mathrm{SiH}_{2}-\mathrm{CH}_{2} \text { (ads) }+ \\
\mathrm{CH}_{3} \text { (ads) } \rightarrow \mathrm{SiH}_{2-} \\
\left(\mathrm{CH}_{2}\right)_{2} \text { (ads) }+\mathrm{H}(\mathrm{g})\end{array}$ & $-3.20 \mathrm{E}-13$ & $2.56 \mathrm{E}-09$ & $-7.37 E-06$ & $-6.61 E-02$ & $5.72 \mathrm{E}+01$ \\
\hline R20 & $\begin{array}{l}{\mathrm{SiCl}-\mathrm{CH}_{2} \text { (ads) }+}^{+} \mathrm{CH}_{3} \text { (ads) } \rightarrow \text { SiHCl- } \\
\left(\mathrm{CH}_{2}\right)_{2} \text { (ads) }\end{array}$ & $3.17 \mathrm{E}-13$ & $-1.88 \mathrm{E}-09$ & $3.42 \mathrm{E}-06$ & $2.25 \mathrm{E}-02$ & $-1.86 \mathrm{E}+02$ \\
\hline R21 & $\begin{array}{l}\mathrm{SiHCl}-\mathrm{CH}_{2} \text { (ads) + } \\
\mathrm{CH}_{3} \text { (ads) } \rightarrow \mathrm{SiHCl}- \\
\left(\mathrm{CH}_{2}\right)_{2} \text { (ads) }+\mathrm{H}(\mathrm{g})\end{array}$ & $-4.83 E-13$ & $3.65 E-09$ & $-1.01 E-05$ & $-6.65 E-02$ & $4.76 \mathrm{E}+01$ \\
\hline $\mathrm{R} 22$ & $\begin{array}{l}\mathrm{SiCl}_{2}-\mathrm{CH}_{2} \text { (ads) }+ \\
\mathrm{CH}_{3}(\mathrm{ads}) \rightarrow \mathrm{SiCl}_{2-} \\
\left(\mathrm{CH}_{2}\right)_{2} \text { (ads) }+\mathrm{H}(\mathrm{g})\end{array}$ & $-5.09 E-13$ & $3.82 \mathrm{E}-09$ & $-1.05 E-05$ & $-6.73 E-02$ & $4.43 E+01$ \\
\hline R23 & $\begin{array}{l}\mathrm{SiH}_{2}-\left(\mathrm{CH}_{2}\right)_{2} \text { (ads) }+ \\
\mathrm{CH}_{3}(\mathrm{ads}) \rightarrow \mathrm{SiH}- \\
\left(\mathrm{CH}_{2}\right)_{3} \text { (ads) }+\mathrm{H}_{2}(\mathrm{~g})\end{array}$ & $-8.77 \mathrm{E}-13$ & 5.67E-09 & $-1.02 E-05$ & $-9.83 E-02$ & $-2.98 \mathrm{E}+01$ \\
\hline R24 & $\begin{array}{l}\mathrm{SiHCl}-\left(\mathrm{CH}_{2}\right)_{2}(\mathrm{ads})+ \\
\mathrm{CH}_{3}(\mathrm{ads}) \rightarrow \mathrm{SiH}- \\
\left(\mathrm{CH}_{2}\right)_{3}(\mathrm{ads})+\mathrm{HCl}(\mathrm{g})\end{array}$ & $1.69 \mathrm{E}-13$ & $-1.51 \mathrm{E}-09$ & $7.59 \mathrm{E}-06$ & $-1.26 \mathrm{E}-01$ & $6.02 E+01$ \\
\hline $\mathrm{R} 25$ & $\begin{array}{c}\mathrm{SiHCl}-\left(\mathrm{CH}_{2}\right)_{2}(\mathrm{ads})+ \\
\mathrm{CH}_{3}(\mathrm{ads}) \rightarrow \mathrm{SiCl}- \\
\left(\mathrm{CH}_{2}\right)_{3}(\mathrm{ads})+\mathrm{H}_{2}(\mathrm{~g})\end{array}$ & $-8.65 E-13$ & $5.58 \mathrm{E}-09$ & $-9.89 E-06$ & $-8.92 \mathrm{E}-02$ & $-3.91 E+01$ \\
\hline R26 & $\begin{array}{c}\mathrm{SiCl}_{2}-\left(\mathrm{CH}_{2}\right)_{2} \text { (ads) }+ \\
\mathrm{CH}_{3}(\mathrm{ads}) \rightarrow \mathrm{SiCl}- \\
\left(\mathrm{CH}_{2}\right)_{3} \text { (ads) }+\mathrm{HCl}(\mathrm{g})\end{array}$ & $3.23 \mathrm{E}-13$ & $-2.60 \mathrm{E}-09$ & $1.05 \mathrm{E}-05$ & $-1.22 \mathrm{E}-01$ & $3.80 E+01$ \\
\hline R27 & $\begin{array}{l}\mathrm{SiH}-\left(\mathrm{CH}_{2}\right)_{3}(\mathrm{ads})+\mathrm{H}(\mathrm{g}) \\
\rightarrow \mathrm{Si}_{-}\left(\mathrm{CH}_{2}\right)_{3}(\mathrm{ads})+ \\
\mathrm{H}_{2}(\mathrm{~g})\end{array}$ & $-3.24 \mathrm{E}-13$ & $1.42 \mathrm{E}-09$ & $1.89 \mathrm{E}-06$ & $-1.56 \mathrm{E}-02$ & $-5.99 E+01$ \\
\hline R28 & $\begin{array}{l}\mathrm{SiCl}-\left(\mathrm{CH}_{2}\right)_{3}(\mathrm{ads})+\mathrm{H}(\mathrm{g}) \\
\rightarrow \mathrm{Si}^{*}\left(\mathrm{CH}_{2}\right)_{3}(\mathrm{ads})+ \\
\mathrm{HCl}(\mathrm{g})\end{array}$ & $7.10 \mathrm{E}-13$ & $-5.66 \mathrm{E}-09$ & $1.94 \mathrm{E}-05$ & $-5.25 E-02$ & $3.94 \mathrm{E}+01$ \\
\hline R29 & $\begin{array}{l}\mathrm{SiH}(\mathrm{g})+\mathrm{H}(\mathrm{ads}) \rightarrow \\
\mathrm{SiH}_{2} \text { (ads) }\end{array}$ & $-3.13 E-13$ & $2.98 \mathrm{E}-09$ & $-1.36 \mathrm{E}-05$ & $1.56 \mathrm{E}-01$ & $-1.98 \mathrm{E}+02$ \\
\hline R30 & $\begin{array}{l}\mathrm{SiH}_{2}(\mathrm{~g})+\mathrm{H}(\mathrm{ads}) \rightarrow \\
\mathrm{SiH}_{3}(\text { ads })\end{array}$ & $-1.34 \mathrm{E}-13$ & 1.91E-09 & $-1.23 E-05$ & 1.77E-01 & $-2.43 E+02$ \\
\hline R31 & $\begin{array}{l}\mathrm{SiCl}(\mathrm{g})+\mathrm{H}(\mathrm{ads}) \rightarrow \\
\mathrm{SiHCl}(\mathrm{ads})\end{array}$ & $-5.63 E-13$ & $4.71 \mathrm{E}-09$ & $-1.81 E-05$ & $1.73 \mathrm{E}-01$ & $-1.51 E+02$ \\
\hline R32 & $\begin{array}{l}\mathrm{SiHCl}(\mathrm{g})+\mathrm{H}(\mathrm{ads}) \rightarrow \\
\mathrm{SiH}_{2} \mathrm{Cl}(\mathrm{ads})\end{array}$ & $-3.38 \mathrm{E}-13$ & $3.29 \mathrm{E}-09$ & $-1.57 E-05$ & $1.98 \mathrm{E}-01$ & $-2.10 E+02$ \\
\hline R33 & $\begin{array}{l}\mathrm{SiCl}_{2}(\mathrm{~g})+\mathrm{H}(\mathrm{ads}) \rightarrow \\
\mathrm{SiHCl}_{2} \text { (ads) }\end{array}$ & $-5.34 \mathrm{E}-13$ & $4.68 \mathrm{E}-09$ & $-1.94 \mathrm{E}-05$ & $2.06 \mathrm{E}-01$ & $-1.55 E+02$ \\
\hline R34 & $\begin{array}{l}\mathrm{SiH}(\mathrm{g})+*(\mathrm{ads}) \rightarrow \\
\mathrm{SiH}(\mathrm{ads})\end{array}$ & $-7.35 \mathrm{E}-14$ & $1.18 \mathrm{E}-09$ & $-8.24 \mathrm{E}-06$ & $1.69 \mathrm{E}-01$ & $-3.45 E+02$ \\
\hline R35 & $\begin{array}{l}\mathrm{SiH}_{2}(\mathrm{~g})+*(\mathrm{ads}) \rightarrow \\
\mathrm{SiH}_{2} \text { (ads) }\end{array}$ & $-1.57 \mathrm{E}-13$ & $1.90 \mathrm{E}-09$ & $-1.15 E-05$ & 1.79E-01 & $-3.06 E+02$ \\
\hline R36 & $\begin{array}{l}\mathrm{SiCl}(\mathrm{g})+*(\mathrm{ads}) \rightarrow \\
\quad \mathrm{SiCl}(\mathrm{ads})\end{array}$ & $-3.19 E-13$ & $2.83 \mathrm{E}-09$ & $-1.23 \mathrm{E}-05$ & $1.83 \mathrm{E}-01$ & $-3.39 E+02$ \\
\hline
\end{tabular}




\begin{tabular}{|c|c|c|c|c|c|c|}
\hline R37 & $\begin{array}{l}\mathrm{SiHCl}(\mathrm{g})+*(\mathrm{ads}) \rightarrow \\
\quad \mathrm{SiHCl}(\mathrm{ads})\end{array}$ & $-2.87 \mathrm{E}-13$ & 2.79E-09 & $-1.37 E-05$ & $1.98 \mathrm{E}-01$ & $-2.70 \mathrm{E}+02$ \\
\hline R38 & $\begin{array}{l}\mathrm{SiCl}_{2}(\mathrm{~g})+*(\mathrm{ads}) \rightarrow \\
\mathrm{SiCl}_{2} \text { (ads) }\end{array}$ & $-4.28 \mathrm{E}-13$ & 3.77E-09 & $-1.62 \mathrm{E}-05$ & $2.03 \mathrm{E}-01$ & $-2.14 \mathrm{E}+02$ \\
\hline R40 & $\begin{array}{l}{ }^{3} \mathrm{Si}(\mathrm{g})+\mathrm{CH}_{3}(\mathrm{ads}) \rightarrow \\
\mathrm{SiH}-\mathrm{CH}_{2} \text { (ads) }\end{array}$ & $-2.19 \mathrm{E}-13$ & $2.22 \mathrm{E}-09$ & $-9.63 E-06$ & $1.43 \mathrm{E}-01$ & $-2.21 \mathrm{E}+02$ \\
\hline R41 & $\begin{array}{l}\mathrm{SiF}(\mathrm{g})+\mathrm{CH}_{3} \text { (ads) } \rightarrow \\
\mathrm{SiHF}-\mathrm{CH}_{2} \text { (ads) }\end{array}$ & $-4.91 E-13$ & $4.40 \mathrm{E}-09$ & $-1.81 E-05$ & $1.65 \mathrm{E}-01$ & $-1.30 \mathrm{E}+02$ \\
\hline R42 & $\begin{array}{l}\mathrm{SiHF}(\mathrm{g})+\mathrm{CH}_{3}(\mathrm{ads}) \rightarrow \\
\mathrm{SiH}_{2} \mathrm{~F}-\mathrm{CH}_{2} \text { (ads) }\end{array}$ & $-3.15 E-13$ & $3.26 \mathrm{E}-09$ & $-1.63 E-05$ & $1.90 \mathrm{E}-01$ & $-1.96 \mathrm{E}+02$ \\
\hline R43 & $\begin{array}{l}\mathrm{SiF}_{2}(\mathrm{~g})+\mathrm{CH}_{3}(\mathrm{ads}) \rightarrow \\
\mathrm{SiHF}_{2}-\mathrm{CH}_{2} \text { (ads) }\end{array}$ & $-5.03 E-13$ & $4.60 \mathrm{E}-09$ & $-1.99 \mathrm{E}-05$ & $1.89 \mathrm{E}-01$ & $-1.41 \mathrm{E}+02$ \\
\hline R44 & $\begin{array}{l}\mathrm{SiBr}(\mathrm{g})+\mathrm{CH}_{3}(\mathrm{ads}) \rightarrow \\
\mathrm{SiHBr}-\mathrm{CH}_{2} \text { (ads) }\end{array}$ & $-5.81 E-13$ & $5.02 \mathrm{E}-09$ & $-1.97 \mathrm{E}-05$ & $1.60 \mathrm{E}-01$ & $-1.22 \mathrm{E}+02$ \\
\hline R45 & $\begin{array}{l}\mathrm{SiHBr}(\mathrm{g})+\mathrm{CH}_{3}(\mathrm{ads}) \rightarrow \\
\mathrm{SiH}_{2} \mathrm{Br}-\mathrm{CH}_{2} \text { (ads) }\end{array}$ & $-3.78 \mathrm{E}-13$ & 3.69E-09 & $-1.74 \mathrm{E}-05$ & 1.91E-01 & $-1.83 E+02$ \\
\hline R46 & $\begin{array}{l}\mathrm{SiBr}_{2}(\mathrm{~g})+\mathrm{CH}_{3}(\mathrm{ads}) \rightarrow \\
\mathrm{SiHBr}_{2}-\mathrm{CH}_{2} \text { (ads) }\end{array}$ & $-5.41 E-13$ & $4.85 E-09$ & $-2.05 E-05$ & $1.94 \mathrm{E}-01$ & $-1.32 \mathrm{E}+02$ \\
\hline R47 & $\begin{array}{l}{ }^{3} \mathrm{Si}(\mathrm{g})+\mathrm{CH}_{2}(\mathrm{ads}) \rightarrow \mathrm{Si}- \\
\mathrm{CH}_{2} \text { (ads) }\end{array}$ & $4.86 \mathrm{E}-13$ & $-3.00 E-09$ & 5.37E-06 & $1.45 \mathrm{E}-01$ & $-3.25 E+02$ \\
\hline R48 & $\begin{array}{l}\mathrm{SiF}(\mathrm{g})+\mathrm{CH}_{2} \text { (ads) } \rightarrow \\
\mathrm{SiF}-\mathrm{CH}_{2} \text { (ads) }\end{array}$ & $1.93 \mathrm{E}-13$ & $-6.01 E-10$ & $-4.02 E-06$ & $1.90 \mathrm{E}-01$ & $-3.21 E+02$ \\
\hline R49 & $\begin{array}{l}\mathrm{SiHF}(\mathrm{g})+\mathrm{CH}_{2} \text { (ads) } \rightarrow \\
\mathrm{SiHF}-\mathrm{CH}_{2} \text { (ads) }\end{array}$ & $2.03 E-13$ & $-5.51 E-10$ & $-5.41 E-06$ & $1.92 \mathrm{E}-01$ & $-2.30 E+02$ \\
\hline R50 & $\begin{array}{l}\mathrm{SiF}_{2}(\mathrm{~g})+\mathrm{CH}_{2} \text { (ads) } \rightarrow \\
\quad \mathrm{SiF}_{2}-\mathrm{CH}_{2} \text { (ads) }\end{array}$ & $3.17 \mathrm{E}-14$ & $6.66 \mathrm{E}-10$ & $-8.71 E-06$ & $1.89 \mathrm{E}-01$ & $-1.67 \mathrm{E}+02$ \\
\hline R51 & $\begin{array}{l}\mathrm{SiBr}(\mathrm{g})+\mathrm{CH}_{2} \text { (ads) } \rightarrow \\
\mathrm{SiBr}^{-\mathrm{CH}_{2}} \text { (ads) }\end{array}$ & $1.38 \mathrm{E}-13$ & $-2.18 \mathrm{E}-10$ & $-5.01 E-06$ & $1.92 \mathrm{E}-01$ & $-3.07 E+02$ \\
\hline R52 & $\begin{array}{l}\mathrm{SiHBr}(\mathrm{g})+\mathrm{CH}_{2} \text { (ads) } \rightarrow \\
\mathrm{SiHBr}-\mathrm{CH}_{2} \text { (ads) }\end{array}$ & $1.53 \mathrm{E}-13$ & $-2.05 E-10$ & $-6.31 E-06$ & $1.87 \mathrm{E}-01$ & $-2.28 \mathrm{E}+02$ \\
\hline R53 & $\begin{array}{l}\mathrm{SiBr}_{2}(\mathrm{~g})+\mathrm{CH}_{2}(\mathrm{ads}) \rightarrow \\
\mathrm{SiBr}_{2}-\mathrm{CH}_{2} \text { (ads) }\end{array}$ & $3.83 \mathrm{E}-14$ & $6.19 E-10$ & $-8.57 E-06$ & $1.90 \mathrm{E}-01$ & $-1.91 \mathrm{E}+02$ \\
\hline R54 & $\begin{array}{l}{ }^{3} \mathrm{Si}(\mathrm{g})+\mathrm{H}(\mathrm{ads}) \rightarrow \\
\mathrm{SiH}(\mathrm{ads})\end{array}$ & $-3.74 \mathrm{E}-13$ & $3.06 \mathrm{E}-09$ & $-1.08 \mathrm{E}-05$ & $1.28 \mathrm{E}-01$ & $-2.23 E+02$ \\
\hline R55 & $\begin{array}{l}\mathrm{SiF}(\mathrm{g})+\mathrm{H}(\mathrm{ads}) \rightarrow \\
\mathrm{SiHF}(\mathrm{ads})\end{array}$ & $-5.59 E-13$ & $4.70 \mathrm{E}-09$ & $-1.82 \mathrm{E}-05$ & $1.65 \mathrm{E}-01$ & $-1.63 E+02$ \\
\hline R56 & $\begin{array}{l}\mathrm{SiHF}(\mathrm{g})+\mathrm{H}(\mathrm{ads}) \rightarrow \\
\mathrm{SiH}_{2} \mathrm{~F}(\mathrm{ads})\end{array}$ & $-2.88 \mathrm{E}-13$ & $2.93 \mathrm{E}-09$ & $-1.48 \mathrm{E}-05$ & $1.95 \mathrm{E}-01$ & $-2.29 E+02$ \\
\hline R57 & $\begin{array}{l}\mathrm{SiF}_{2}(\mathrm{~g})+\mathrm{H}(\mathrm{ads}) \rightarrow \\
\quad \mathrm{SiHF}_{2} \text { (ads) }\end{array}$ & $-4.21 \mathrm{E}-13$ & 3.89E-09 & $-1.74 \mathrm{E}-05$ & $2.00 \mathrm{E}-01$ & $-1.78 E+02$ \\
\hline R58 & $\begin{array}{l}\mathrm{SiBr}(\mathrm{g})+\mathrm{H}(\mathrm{ads}) \rightarrow \\
\mathrm{SiHBr}(\mathrm{ads})\end{array}$ & $-5.95 E-13$ & $4.93 \mathrm{E}-09$ & $-1.86 \mathrm{E}-05$ & $1.73 \mathrm{E}-01$ & $-1.49 E+02$ \\
\hline R59 & $\begin{array}{l}\mathrm{SiHBr}(\mathrm{g})+\mathrm{H}(\mathrm{ads}) \rightarrow \\
\mathrm{SiH}_{2} \mathrm{Br}(\mathrm{ads})\end{array}$ & $-3.01 E-13$ & $3.02 \mathrm{E}-09$ & $-1.50 \mathrm{E}-05$ & $2.01 \mathrm{E}-01$ & $-2.07 E+02$ \\
\hline
\end{tabular}




\begin{tabular}{|c|c|c|c|c|c|c|}
\hline R60 & $\begin{array}{l}\mathrm{SiBr}_{2}(\mathrm{~g})+\mathrm{H}(\mathrm{ads}) \rightarrow \\
\mathrm{SiHBr}_{2}(\mathrm{ads})\end{array}$ & $-6.27 E-13$ & $5.30 \mathrm{E}-09$ & $-2.10 \mathrm{E}-05$ & $2.05 \mathrm{E}-01$ & $-1.43 E+02$ \\
\hline R61 & $\begin{array}{l}{ }^{3} \mathrm{Si}(\mathrm{g})+*(\mathrm{ads}) \rightarrow \\
\quad \mathrm{Si}(\text { ads })\end{array}$ & $-7.90 \mathrm{E}-14$ & $7.76 \mathrm{E}-10$ & $-3.78 \mathrm{E}-06$ & $1.35 \mathrm{E}-01$ & $-3.54 \mathrm{E}+02$ \\
\hline R62 & $\begin{array}{l}\mathrm{SiF}(\mathrm{g})+*(\mathrm{ads}) \rightarrow \\
\quad \mathrm{SiF}(\mathrm{ads})\end{array}$ & $-2.90 \mathrm{E}-13$ & $2.63 \mathrm{E}-09$ & $-1.18 \mathrm{E}-05$ & $1.82 \mathrm{E}-01$ & $-3.58 \mathrm{E}+02$ \\
\hline R63 & $\begin{array}{l}\mathrm{SiHF}(\mathrm{g})+*(\mathrm{ads}) \rightarrow \\
\mathrm{SiHF}(\mathrm{ads})\end{array}$ & $-3.09 E-13$ & $2.95 \mathrm{E}-09$ & $-1.42 \mathrm{E}-05$ & $1.90 \mathrm{E}-01$ & $-2.78 \mathrm{E}+02$ \\
\hline R64 & $\begin{array}{l}\mathrm{SiF}_{2}(\mathrm{~g})+*(\mathrm{ads}) \rightarrow \\
\mathrm{SiF}_{2} \text { (ads) }\end{array}$ & $-4.33 E-13$ & 3.79E-09 & $-1.64 \mathrm{E}-05$ & $1.94 \mathrm{E}-01$ & $-2.17 \mathrm{E}+02$ \\
\hline R65 & $\begin{array}{l}\mathrm{SiBr}(\mathrm{g})+*(\text { ads }) \rightarrow \\
\mathrm{SiBr}(\mathrm{ads})\end{array}$ & $-2.20 \mathrm{E}-13$ & $2.13 \mathrm{E}-09$ & $-1.05 E-05$ & $1.88 \mathrm{E}-01$ & $-3.37 E+02$ \\
\hline R66 & $\begin{array}{l}\mathrm{SiHBr}(\mathrm{g})+*(\text { ads }) \rightarrow \\
\quad \mathrm{SiHBr}(\mathrm{ads})\end{array}$ & $-3.02 E-13$ & 2.89E-09 & $-1.40 \mathrm{E}-05$ & $1.98 \mathrm{E}-01$ & $-2.71 E+02$ \\
\hline R67 & $\begin{array}{l}\mathrm{SiBr}_{2}(\mathrm{~g})+*(\mathrm{ads}) \rightarrow \\
\mathrm{SiBr}_{2} \text { (ads) }\end{array}$ & $-4.78 \mathrm{E}-13$ & 4.10E-09 & $-1.70 \mathrm{E}-05$ & $2.05 \mathrm{E}-01$ & $-2.12 E+02$ \\
\hline
\end{tabular}

Table S2 Gibbs free energies of activation in $\mathrm{kJ} / \mathrm{mol}$ at the temperature range of 298 $2500 \mathrm{~K}$.

$$
\Delta G^{\ddagger}=a_{1} T^{4}+a_{2} T^{3}+a_{3} T^{2}+a_{4} T+a_{5} \text { for temperature }(\mathrm{T})=298-2500 \mathrm{~K} .
$$

\begin{tabular}{|c|c|c|c|c|c|c|}
\hline & & $a_{1}$ & $a_{2}$ & $a_{3}$ & $a_{4}$ & $a_{5}$ \\
\hline R1 & $\begin{array}{l}\mathrm{SiH}(\mathrm{g})+\mathrm{CH}_{3}(\mathrm{ads}) \rightarrow \\
\mathrm{SiH}_{2}-\mathrm{CH}_{2} \text { (ads) }\end{array}$ & $-4.57 E-13$ & $3.78 \mathrm{E}-09$ & $-1.32 E-05$ & $1.46 \mathrm{E}-01$ & $7.82 E+01$ \\
\hline $\mathrm{R} 2$ & $\begin{array}{l}\mathrm{SiH}_{2}(\mathrm{~g})+\mathrm{CH}_{3}(\mathrm{ads}) \rightarrow \\
\mathrm{SiH}_{3}-\mathrm{CH}_{2} \text { (ads) }\end{array}$ & $-3.76 \mathrm{E}-13$ & 3.31E-09 & $-1.32 \mathrm{E}-05$ & $1.65 \mathrm{E}-01$ & $8.32 E+01$ \\
\hline R3 & $\begin{array}{l}\mathrm{SiCl}(\mathrm{g})+\mathrm{CH}_{3}(\mathrm{ads}) \rightarrow \\
\mathrm{SiHCl}-\mathrm{CH}_{2} \text { (ads) }\end{array}$ & $-7.22 \mathrm{E}-13$ & 5.60E-09 & $-1.79 \mathrm{E}-05$ & $1.54 \mathrm{E}-01$ & $1.05 E+02$ \\
\hline $\mathrm{R} 4$ & $\begin{array}{l}\mathrm{SiHCl}(\mathrm{g})+\mathrm{CH}_{3}(\mathrm{ads}) \rightarrow \\
\mathrm{SiH}_{2} \mathrm{Cl}-\mathrm{CH}_{2} \text { (ads) }\end{array}$ & $-5.83 E-13$ & $4.75 E-09$ & $-1.70 \mathrm{E}-05$ & $1.80 \mathrm{E}-01$ & $1.20 E+02$ \\
\hline R5 & $\begin{array}{c}\mathrm{SiCl}_{2}(\mathrm{~g})+\mathrm{CH}_{3}(\mathrm{ads}) \rightarrow \\
\mathrm{SiHCl}_{2}-\mathrm{CH}_{2}(\mathrm{ads})\end{array}$ & $-7.00 \mathrm{E}-13$ & $5.60 \mathrm{E}-09$ & $-1.94 \mathrm{E}-05$ & $1.83 \mathrm{E}-01$ & $1.89 \mathrm{E}+02$ \\
\hline R11 & $\begin{array}{l}\mathrm{SiH}(\mathrm{g})+\mathrm{C}_{2} \mathrm{H}_{4}(\mathrm{ads}) \rightarrow \\
\mathrm{SiH}-\left(\mathrm{CH}_{2}\right)_{2} \text { (ads) }\end{array}$ & $-6.81 E-13$ & 4.99E-09 & $-1.48 \mathrm{E}-05$ & $1.44 \mathrm{E}-01$ & $1.38 \mathrm{E}+02$ \\
\hline R12 & $\begin{array}{c}\mathrm{SiH}_{2}(\mathrm{~g})+\mathrm{C}_{2} \mathrm{H}_{4} \text { (ads) } \rightarrow \\
\mathrm{SiH}_{2}-\left(\mathrm{CH}_{2}\right)_{2} \text { (ads) }\end{array}$ & $-8.40 \mathrm{E}-13$ & $6.23 \mathrm{E}-09$ & $-1.94 \mathrm{E}-05$ & 1.57E-01 & $2.04 \mathrm{E}+02$ \\
\hline R13 & $\begin{array}{l}\mathrm{SiCl}(\mathrm{g})+\mathrm{C}_{2} \mathrm{H}_{4} \text { (ads) } \rightarrow \\
\mathrm{SiCl}-\left(\mathrm{CH}_{2}\right)_{2} \text { (ads) }\end{array}$ & $-9.03 E-13$ & 6.49E-09 & $-1.85 \mathrm{E}-05$ & $1.45 \mathrm{E}-01$ & $1.49 \mathrm{E}+02$ \\
\hline
\end{tabular}




\begin{tabular}{|c|c|c|c|c|c|c|}
\hline R14 & $\begin{array}{l}\mathrm{SiHCl}(\mathrm{g})+\mathrm{C}_{2} \mathrm{H}_{4} \text { (ads) } \rightarrow \\
\mathrm{SiHCl}-\left(\mathrm{CH}_{2}\right)_{2} \text { (ads) }\end{array}$ & $-9.87 E-13$ & $7.22 \mathrm{E}-09$ & $-2.18 \mathrm{E}-05$ & $1.73 \mathrm{E}-01$ & $2.34 \mathrm{E}+02$ \\
\hline R15 & $\begin{array}{l}\mathrm{SiCl}_{2}(\mathrm{~g})+\mathrm{C}_{2} \mathrm{H}_{4}(\mathrm{ads}) \rightarrow \\
\mathrm{SiCl}_{2}-\left(\mathrm{CH}_{2}\right)_{2} \text { (ads) }\end{array}$ & $-1.20 \mathrm{E}-12$ & 8.65E-09 & $-2.53 \mathrm{E}-05$ & $1.71 \mathrm{E}-01$ & $2.78 \mathrm{E}+02$ \\
\hline R18 & $\begin{array}{l}\mathrm{SiH}-\mathrm{CH}_{2} \text { (ads) }+ \\
\mathrm{CH}_{3}(\mathrm{ads}) \rightarrow \mathrm{SiH}_{2-} \\
\left(\mathrm{CH}_{2}\right)_{2} \text { (ads) }\end{array}$ & $2.85 \mathrm{E}-13$ & $-2.08 \mathrm{E}-09$ & 7.37E-06 & $2.31 \mathrm{E}-02$ & $9.17 \mathrm{E}+01$ \\
\hline R19 & $\begin{array}{l}\mathrm{SiH}_{2}-\mathrm{CH}_{2} \text { (ads) }+ \\
\mathrm{CH}_{3}(\mathrm{ads}) \rightarrow \mathrm{SiH}_{2-} \\
\left(\mathrm{CH}_{2}\right)_{2}(\mathrm{ads})+\mathrm{H}(\mathrm{g})\end{array}$ & $1.72 \mathrm{E}-13$ & $-1.03 E-09$ & $3.51 \mathrm{E}-06$ & $3.51 \mathrm{E}-02$ & $1.73 \mathrm{E}+02$ \\
\hline R20 & $\begin{array}{l}\text { SiCl-CH } \mathrm{CH}_{2} \text { (ads) }+ \\
\quad \mathrm{CH}_{3} \text { (ads) } \rightarrow \text { SiHCl- } \\
\quad\left(\mathrm{CH}_{2}\right)_{2} \text { (ads) }\end{array}$ & $1.75 \mathrm{E}-13$ & $-1.30 \mathrm{E}-09$ & $5.24 \mathrm{E}-06$ & $1.27 \mathrm{E}-02$ & $1.41 \mathrm{E}+02$ \\
\hline R21 & $\begin{array}{l}\mathrm{SiHCl}-\mathrm{CH}_{2} \text { (ads) }+ \\
\mathrm{CH}_{3}(\mathrm{ads}) \rightarrow \mathrm{SiHCl}- \\
\left(\mathrm{CH}_{2}\right)_{2} \text { (ads) }+\mathrm{H}(\mathrm{g})\end{array}$ & $1.05 \mathrm{E}-13$ & $-5.95 E-10$ & $2.48 \mathrm{E}-06$ & $3.52 \mathrm{E}-02$ & $1.63 \mathrm{E}+02$ \\
\hline $\mathrm{R} 22$ & $\begin{array}{l}\mathrm{SiCl}_{2}-\mathrm{CH}_{2} \text { (ads) + } \\
\mathrm{CH}_{3}(\mathrm{ads}) \rightarrow \mathrm{SiCl}_{2-} \\
\left(\mathrm{CH}_{2}\right)_{2}(\mathrm{ads})+\mathrm{H}(\mathrm{g})\end{array}$ & $9.10 \mathrm{E}-15$ & $2.02 \mathrm{E}-10$ & $-2.47 \mathrm{E}-07$ & $2.16 \mathrm{E}-02$ & $1.87 \mathrm{E}+02$ \\
\hline $\mathrm{R} 23$ & $\begin{array}{c}\mathrm{SiH}_{2}-\left(\mathrm{CH}_{2}\right)_{2} \text { (ads) }+ \\
\mathrm{CH}_{3} \text { (ads) } \rightarrow \mathrm{SiH}- \\
\left(\mathrm{CH}_{2}\right)_{3} \text { (ads) }+\mathrm{H}_{2}(\mathrm{~g})\end{array}$ & $1.06 \mathrm{E}-13$ & $-4.55 \mathrm{E}-10$ & $1.42 \mathrm{E}-06$ & $8.37 \mathrm{E}-03$ & $2.90 \mathrm{E}+02$ \\
\hline R24 & $\begin{array}{l}\mathrm{SiHCl}-\left(\mathrm{CH}_{2}\right)_{2}(\mathrm{ads})+ \\
\mathrm{CH}_{3}(\mathrm{ads}) \rightarrow \mathrm{SiH}- \\
\left(\mathrm{CH}_{2}\right)_{3} \text { (ads) }+\mathrm{HCl}(\mathrm{g})\end{array}$ & $2.71 \mathrm{E}-13$ & $-2.01 \mathrm{E}-09$ & $7.14 \mathrm{E}-06$ & $1.33 \mathrm{E}-02$ & $2.29 \mathrm{E}+02$ \\
\hline $\mathrm{R} 25$ & $\begin{array}{c}\mathrm{SiHCl}-\left(\mathrm{CH}_{2}\right)_{2} \text { (ads) }+ \\
\mathrm{CH}_{3}(\mathrm{ads}) \rightarrow \mathrm{SiCl}- \\
\left(\mathrm{CH}_{2}\right)_{3}(\mathrm{ads})+\mathrm{H}_{2}(\mathrm{~g})\end{array}$ & $1.16 \mathrm{E}-13$ & $-6.45 \mathrm{E}-10$ & $2.42 \mathrm{E}-06$ & $9.80 \mathrm{E}-03$ & $2.65 \mathrm{E}+02$ \\
\hline R26 & $\begin{array}{l}\mathrm{SiCl}_{2}-\left(\mathrm{CH}_{2}\right)_{2} \text { (ads) }+ \\
\mathrm{CH}_{3}(\mathrm{ads}) \rightarrow \mathrm{SiCl}- \\
\left(\mathrm{CH}_{2}\right)_{3} \text { (ads) }+\mathrm{HCl}(\mathrm{g})\end{array}$ & $5.25 \mathrm{E}-13$ & $-3.65 E-09$ & 1.09E-05 & $1.45 \mathrm{E}-02$ & $2.40 \mathrm{E}+02$ \\
\hline R27 & $\begin{array}{l}\mathrm{SiH}-\left(\mathrm{CH}_{2}\right)_{3}(\mathrm{ads})+\mathrm{H}(\mathrm{g}) \\
\rightarrow \mathrm{Si}^{*}-\left(\mathrm{CH}_{2}\right)_{3}(\mathrm{ads})+ \\
\mathrm{H}_{2}(\mathrm{~g})\end{array}$ & $1.95 \mathrm{E}-13$ & $-1.46 \mathrm{E}-09$ & $5.04 \mathrm{E}-06$ & $8.58 \mathrm{E}-02$ & $9.45 \mathrm{E}+00$ \\
\hline R28 & $\begin{array}{l}\mathrm{SiCl}-\left(\mathrm{CH}_{2}\right)_{3}(\mathrm{ads})+\mathrm{H}(\mathrm{g}) \\
\rightarrow \mathrm{Si}^{*}\left(\mathrm{CH}_{2}\right)_{3}(\mathrm{ads})+ \\
\mathrm{HCl}(\mathrm{g})\end{array}$ & $3.24 \mathrm{E}-13$ & $-2.40 \mathrm{E}-09$ & 7.67E-06 & $8.36 \mathrm{E}-02$ & $8.60 E+01$ \\
\hline R29 & $\begin{array}{l}\mathrm{SiH}(\mathrm{g})+\mathrm{H}(\mathrm{ads}) \rightarrow \\
\mathrm{SiH}_{2} \text { (ads) }\end{array}$ & $-3.92 \mathrm{E}-13$ & $3.16 \mathrm{E}-09$ & $-1.09 E-05$ & $1.44 \mathrm{E}-01$ & $4.48 \mathrm{E}+01$ \\
\hline R30 & $\begin{array}{l}\mathrm{SiH}_{2}(\mathrm{~g})+\mathrm{H}(\mathrm{ads}) \rightarrow \\
\mathrm{SiH}_{3}(\mathrm{ads})\end{array}$ & $-3.15 E-13$ & $2.75 \mathrm{E}-09$ & $-1.11 \mathrm{E}-05$ & $1.70 \mathrm{E}-01$ & $5.73 \mathrm{E}+01$ \\
\hline R31 & $\begin{array}{l}\mathrm{SiCl}(\mathrm{g})+\mathrm{H}(\mathrm{ads}) \rightarrow \\
\quad \mathrm{SiHCl}(\mathrm{ads})\end{array}$ & $-6.32 E-13$ & $4.81 \mathrm{E}-09$ & $-1.51 \mathrm{E}-05$ & $1.54 \mathrm{E}-01$ & $7.82 \mathrm{E}+01$ \\
\hline R32 & $\begin{array}{l}\mathrm{SiHCl}(\mathrm{g})+\mathrm{H}(\mathrm{ads}) \rightarrow \\
\mathrm{SiH}_{2} \mathrm{Cl}(\mathrm{ads})\end{array}$ & $-6.07 E-13$ & $4.72 \mathrm{E}-09$ & $-1.60 \mathrm{E}-05$ & $1.82 \mathrm{E}-01$ & $1.15 \mathrm{E}+02$ \\
\hline
\end{tabular}




\begin{tabular}{|c|l|l|l|l|l|l|}
\hline R33 & $\begin{array}{l}\mathrm{SiCl}_{2}(\mathrm{~g})+\mathrm{H}(\mathrm{ads}) \rightarrow \\
\mathrm{SiHCl}_{2} \text { (ads) }\end{array}$ & $-7.37 \mathrm{E}-13$ & $5.66 \mathrm{E}-09$ & $-1.86 \mathrm{E}-05$ & $1.88 \mathrm{E}-01$ & $1.92 \mathrm{E}+02$ \\
\hline
\end{tabular}

Table S3 Sticking coefficients, $S=A T^{n} \exp (-E / R T)$, at the temperature range of 298 $2500 \mathrm{~K}$. The energy (E) is in the unit of $\mathrm{kJ} / \mathrm{mol}$.

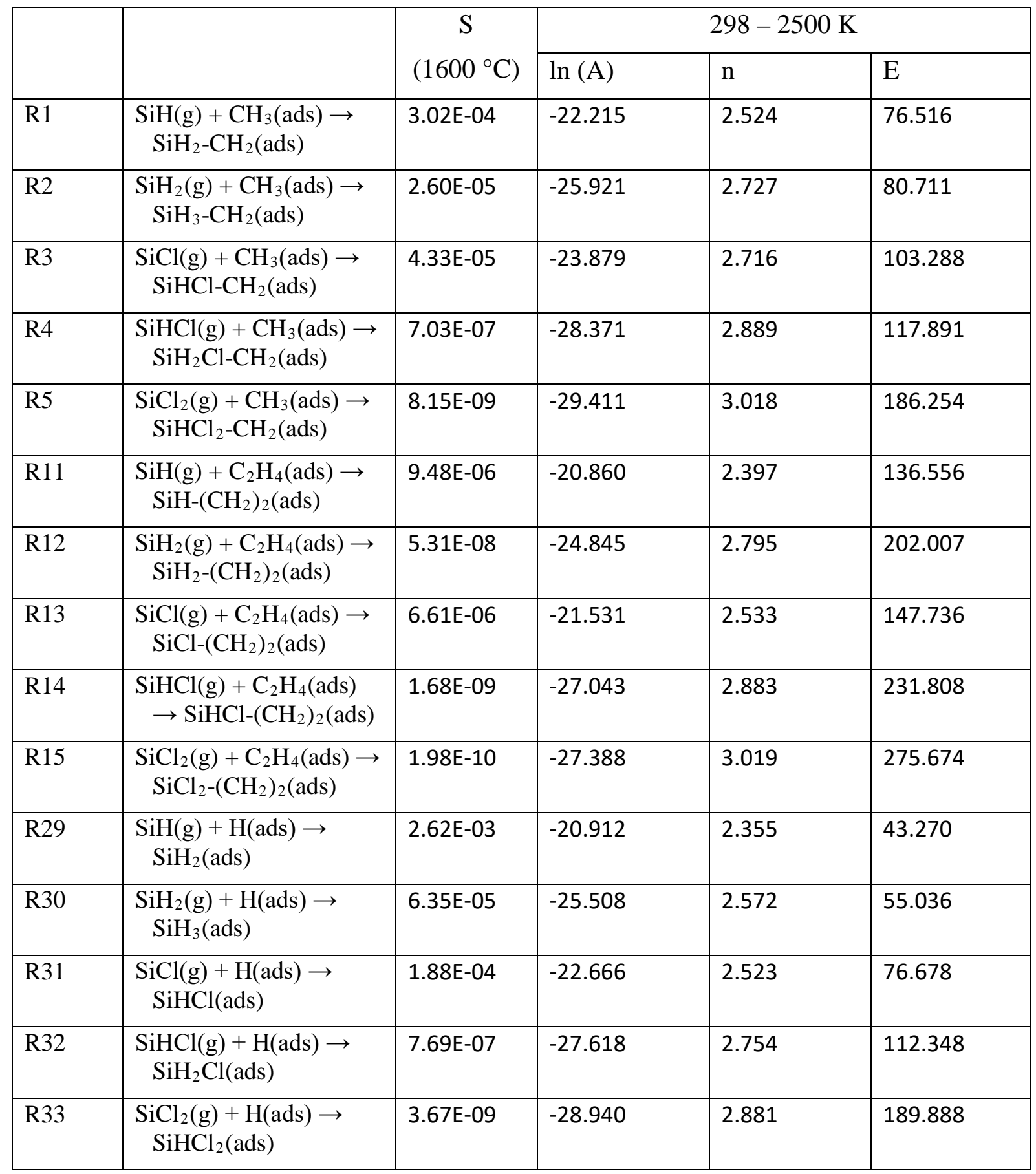


Table S4 Rate constants in forward and reverse directions. $\mathrm{A}$ and $\mathrm{E}$ are in the units of molecules per site per second and $\mathrm{kJ} / \mathrm{mol}$.

\begin{tabular}{|c|c|c|c|c|c|c|c|}
\hline & & \multicolumn{3}{|c|}{ Forward rate constants } & \multicolumn{3}{|c|}{ Reverse rate constants } \\
\hline & & $\ln (\mathrm{A})$ & $\mathrm{n}$ & $\mathrm{E}$ & $\ln (\mathrm{A})$ & $\mathrm{n}$ & $\mathrm{E}$ \\
\hline R18 & $\begin{array}{l}\mathrm{SiH}-\mathrm{CH}_{2} \text { (ads) }+\mathrm{CH}_{3} \text { (ads) } \\
\rightarrow \mathrm{SiH}_{2}-\left(\mathrm{CH}_{2}\right)_{2} \text { (ads) }\end{array}$ & 25.088 & 0.334 & 93.129 & 28.915 & 0.381 & 316.595 \\
\hline R19 & $\begin{array}{l}\mathrm{SiH}_{2}-\mathrm{CH}_{2} \text { (ads) }+\mathrm{CH}_{3} \text { (ads) } \\
\quad \rightarrow \mathrm{SiH}_{2}-\left(\mathrm{CH}_{2}\right)_{2} \text { (ads) }+ \\
\quad \mathrm{H}(\mathrm{g})\end{array}$ & 21.913 & 0.629 & 173.923 & 3.526 & 0.450 & 116.164 \\
\hline R20 & $\begin{array}{l}\mathrm{SiCl}-\mathrm{CH}_{2} \text { (ads) }+\mathrm{CH}_{3} \text { (ads) } \\
\rightarrow \mathrm{SiHCl}-\left(\mathrm{CH}_{2}\right)_{2} \text { (ads) }\end{array}$ & 25.760 & 0.442 & 141.871 & 28.983 & 0.405 & 328.009 \\
\hline R21 & $\begin{array}{l}\mathrm{SiHCl}-\mathrm{CH}_{2} \text { (ads) }+ \\
\quad \mathrm{CH}_{3}(\mathrm{ads}) \rightarrow \mathrm{SiHCl}- \\
\quad\left(\mathrm{CH}_{2}\right)_{2} \text { (ads) }+\mathrm{H}(\mathrm{g})\end{array}$ & 21.767 & 0.663 & 163.960 & 3.809 & 0.382 & 115.888 \\
\hline R22 & $\begin{array}{l}\mathrm{SiCl}_{2}-\mathrm{CH}_{2} \text { (ads) }+\mathrm{CH}_{3} \text { (ads) } \\
\rightarrow \mathrm{SiCl}_{2}-\left(\mathrm{CH}_{2}\right)_{2} \text { (ads) }+ \\
\mathrm{H}(\mathrm{g})\end{array}$ & 22.261 & 0.859 & 187.453 & 6.906 & 0.240 & 145.684 \\
\hline R23 & $\begin{array}{l}\mathrm{SiH}_{2}-\left(\mathrm{CH}_{2}\right)_{2} \text { (ads) }+ \\
\quad \mathrm{CH}_{3}(\mathrm{ads}) \rightarrow \mathrm{SiH}^{-} \\
\quad\left(\mathrm{CH}_{2}\right)_{3}(\mathrm{ads})+\mathrm{H}_{2}(\mathrm{~g})\end{array}$ & 24.102 & 0.799 & 290.502 & -3.375 & 1.370 & 316.249 \\
\hline R24 & $\begin{array}{l}\mathrm{SiHCl}\left(\mathrm{CH}_{2}\right)_{2}(\mathrm{ads})+ \\
\quad \mathrm{CH}_{3}(\mathrm{ads}) \rightarrow \mathrm{SiH}- \\
\quad\left(\mathrm{CH}_{2}\right)_{3}(\mathrm{ads})+\mathrm{HCl}(\mathrm{g})\end{array}$ & 26.089 & 0.362 & 230.300 & -6.274 & 1.372 & 167.938 \\
\hline R25 & $\begin{array}{l}\mathrm{SiHCl}-\left(\mathrm{CH}_{2}\right)_{2}(\mathrm{ads})+ \\
\quad \mathrm{CH}_{3}(\mathrm{ads}) \rightarrow \mathrm{SiCl}- \\
\quad\left(\mathrm{CH}_{2}\right)_{3}(\mathrm{ads})+\mathrm{H}_{2}(\mathrm{~g})\end{array}$ & 24.630 & 0.688 & 266.089 & -2.919 & 1.274 & 301.090 \\
\hline R26 & $\begin{array}{l}\mathrm{SiCl}_{2}-\left(\mathrm{CH}_{2}\right)_{2}(\mathrm{ads})+ \\
\quad \mathrm{CH}_{3}(\mathrm{ads}) \rightarrow \mathrm{SiCl}- \\
\quad\left(\mathrm{CH}_{2}\right)_{3}(\mathrm{ads})+\mathrm{HCl}(\mathrm{g})\end{array}$ & 25.932 & 0.311 & 241.019 & -7.590 & 1.435 & 201.034 \\
\hline R27 & $\begin{array}{r}\mathrm{SiH}-\left(\mathrm{CH}_{2}\right)_{3}(\mathrm{ads})+\mathrm{H}(\mathrm{g}) \rightarrow \\
\mathrm{Si}^{*}-\left(\mathrm{CH}_{2}\right)_{3}(\mathrm{ads})+\mathrm{H}_{2}(\mathrm{~g})\end{array}$ & 6.449 & 0.603 & 10.898 & -3.942 & 1.654 & 66.495 \\
\hline R28 & $\begin{array}{l}\mathrm{SiCl}-\left(\mathrm{CH}_{2}\right)_{3}(\mathrm{ads})+\mathrm{H}(\mathrm{g}) \rightarrow \\
\mathrm{Si}^{*}-\left(\mathrm{CH}_{2}\right)_{3}(\mathrm{ads})+ \\
\mathrm{HCl}(\mathrm{g})\end{array}$ & 6.141 & 0.492 & 87.315 & -8.998 & 1.959 & 45.603 \\
\hline R29 & $\begin{array}{l}\mathrm{SiH}(\mathrm{g})+\mathrm{H}(\mathrm{ads}) \rightarrow \\
\quad \mathrm{SiH}_{2} \text { (ads) }\end{array}$ & -10.563 & 1.884 & 43.884 & 29.320 & 0.393 & 244.838 \\
\hline R30 & $\begin{array}{l}\mathrm{SiH}_{2}(\mathrm{~g})+\mathrm{H}(\mathrm{ads}) \rightarrow \\
\quad \mathrm{SiH}_{3} \text { (ads) }\end{array}$ & -15.192 & 2.103 & 55.638 & 28.581 & 0.428 & 302.576 \\
\hline R31 & $\begin{array}{l}\mathrm{SiCl}(\mathrm{g})+\mathrm{H}(\mathrm{ads}) \rightarrow \\
\mathrm{SiHCl}(\mathrm{ads})\end{array}$ & -12.736 & 2.056 & 77.259 & 30.230 & 0.372 & 230.536 \\
\hline R32 & $\begin{array}{l}\mathrm{SiHCl}(\mathrm{g})+\mathrm{H}(\mathrm{ads}) \rightarrow \\
\mathrm{SiH}_{2} \mathrm{Cl}(\mathrm{ads})\end{array}$ & -17.679 & 2.285 & 112.951 & 29.360 & 0.486 & 326.841 \\
\hline
\end{tabular}




\begin{tabular}{|l|l|l|l|l|l|l|l|}
\hline R33 & $\begin{array}{l}\mathrm{SiCl}_{2}(\mathrm{~g})+\mathrm{H}(\mathrm{ads}) \rightarrow \\
\mathrm{SiHCl}_{2} \text { (ads) }\end{array}$ & -19.224 & 2.413 & 190.480 & 29.782 & 0.449 & 349.358 \\
\hline
\end{tabular}

Table S4 Molecular Coordinates in Z-matrix form

\section{$\mathrm{CH}_{3}$ (ads)}

$\mathrm{Si}$

$\begin{array}{lll}\text { Si } & 1 & \text { B1 }\end{array}$

$\begin{array}{lll}\mathrm{Si} & 1 & \mathrm{~B} 2\end{array}$

$\begin{array}{lll}\mathrm{Si} & 2 & \mathrm{~B} 3\end{array}$

$\begin{array}{lll}\text { Si } & 2 & \text { B4 }\end{array}$

$\begin{array}{lll}\mathrm{Si} & 5 & \text { B5 }\end{array}$

$\begin{array}{lll}\mathrm{Si} & 3 & \text { B6 }\end{array}$

$\begin{array}{lll}\mathrm{Si} & 2 & \mathrm{~B} 7\end{array}$

$\begin{array}{lll}\mathrm{Si} & 2 & \text { B8 }\end{array}$

$\begin{array}{lll}\mathrm{Si} & 7 & \text { B9 }\end{array}$

$\begin{array}{lll}\mathrm{Si} & 9 & \mathrm{~B} 10\end{array}$

B11

B12

B13

B14

B15

B16

B17

B18

B19

B20

B21

B22

B23

B24

B25

B26

B27

B28

B29

B30

B31

B32

B33

B34

B35

B36

B37

B38

B39

B40

B41

B42

B43

$$
2
$$

1

1

2

1

1

1

3

2

1

$$
\begin{aligned}
& 1 \\
& 5
\end{aligned}
$$

$$
3
$$

1

1

3

3

9

7

3

3
3

3

3
2

2
14

1

1

2

12

5

11

10

7

12

7

9

2

1

12

12
7

19

3

38

38

36

36

A1

$\begin{array}{lll}\text { A2 } & 3 & \text { D1 }\end{array}$

A3 $\quad 3 \quad$ D2

$\begin{array}{lll}\text { A4 } & 1 & \text { D3 }\end{array}$

$\begin{array}{lll}\text { A5 } & 6 & \text { D4 }\end{array}$

$\begin{array}{lll}\text { A6 } & 3 & \text { D5 }\end{array}$

$\begin{array}{lll}\text { A7 } & 3 & \text { D6 }\end{array}$

$\begin{array}{lll}\text { A8 } & 1 & \text { D7 }\end{array}$

$\begin{array}{lll}\text { A9 } & 1 & \text { D8 }\end{array}$

$\begin{array}{lll}\text { A10 } & 6 & \text { D9 }\end{array}$

$\begin{array}{lll}\text { A11 } & 2 & \text { D10 }\end{array}$

$\begin{array}{lll}\text { A12 } & 12 & \text { D11 }\end{array}$

$\begin{array}{lll}\text { A13 } & 14 & \text { D12 }\end{array}$

$\begin{array}{lll}\text { A14 } & 1 & \text { D13 }\end{array}$

$\begin{array}{lll}\text { A15 } & 2 & \text { D14 }\end{array}$

$\begin{array}{lll}\text { A16 } & 3 & \text { D15 }\end{array}$

$\begin{array}{lll}\text { A17 } & 1 & \text { D16 }\end{array}$

$\begin{array}{lll}\text { A18 } & 1 & \text { D17 }\end{array}$

$\begin{array}{lll}\text { A19 } & 1 & \text { D18 }\end{array}$

$\begin{array}{lll}\text { A20 } & 1 & \text { D19 }\end{array}$

$\begin{array}{lll}\text { A21 } & 3 & \text { D20 }\end{array}$

$\begin{array}{lll}\text { A22 } & 14 & \text { D21 }\end{array}$

$\begin{array}{lll}\text { A23 } & 14 & \text { D22 }\end{array}$

$\begin{array}{lll}\text { A24 } & 1 & \text { D23 }\end{array}$

$\begin{array}{lll}\text { A25 } & 3 & \text { D24 }\end{array}$

$\begin{array}{lll}\text { A26 } & 2 & \text { D25 }\end{array}$

$\begin{array}{lll}\text { A27 } & 9 & \text { D26 }\end{array}$

$\begin{array}{lll}\text { A28 } & 7 & \text { D27 }\end{array}$

$\begin{array}{lll}\text { A29 } & 3 & \text { D28 }\end{array}$

$\begin{array}{lll}\text { A30 } & 3 & \text { D29 }\end{array}$

$\begin{array}{lll}\text { A31 } & 3 & \text { D30 }\end{array}$

$\begin{array}{lll}\text { A32 } & 2 & \text { D31 }\end{array}$

$\begin{array}{lll}\text { A33 } & 1 & \text { D32 }\end{array}$

$\begin{array}{lll}\text { A34 } & 14 & \text { D33 }\end{array}$

$\begin{array}{lll}\text { A35 } & 3 & \text { D34 }\end{array}$

$\begin{array}{lll}\text { A36 } & 3 & \text { D35 }\end{array}$

$\begin{array}{lll}\text { A37 } & 7 & \text { D36 }\end{array}$

$\begin{array}{lll}\text { A38 } & 1 & \text { D37 }\end{array}$

$\begin{array}{lll}\text { A39 } & 19 & \text { D38 }\end{array}$

$\begin{array}{lll}\text { A40 } & 19 & \text { D39 }\end{array}$

$\begin{array}{lll}\text { A41 } & 3 & \text { D40 }\end{array}$

$\begin{array}{lll}\text { A42 } & 3 & \text { D41 }\end{array}$ 


$\begin{array}{lllllll}\mathrm{H} & 38 & \mathrm{~B} 44 & 19 & \mathrm{~A} 43 & 7 & \mathrm{D} 42 \\ \mathrm{H} & 7 & \mathrm{~B} 45 & 3 & \mathrm{~A} 44 & 1 & \mathrm{D} 43 \\ \mathrm{H} & 36 & \mathrm{~B} 46 & 3 & \mathrm{~A} 45 & 1 & \mathrm{D} 44 \\ \mathrm{H} & 14 & \mathrm{~B} 47 & 1 & \mathrm{~A} 46 & 3 & \mathrm{D} 45 \\ \mathrm{H} & 13 & \mathrm{~B} 48 & 6 & \mathrm{~A} 47 & 5 & \mathrm{D} 46 \\ \mathrm{H} & 11 & \mathrm{~B} 49 & 9 & \mathrm{~A} 48 & 2 & \mathrm{D} 47 \\ \mathrm{C} & 1 & \mathrm{~B} 50 & 14 & \mathrm{~A} 49 & 3 & \mathrm{D} 48 \\ \mathrm{C} & 2 & \mathrm{~B} 51 & 1 & \mathrm{~A} 50 & 14 & \mathrm{D} 49 \\ \mathrm{C} & 3 & \mathrm{~B} 52 & 1 & \mathrm{~A} 51 & 14 & \mathrm{D} 50 \\ \mathrm{Si} & 53 & \mathrm{~B} 53 & 3 & \mathrm{~A} 52 & 1 & \mathrm{D} 51 \\ \mathrm{H} & 5 & \mathrm{~B} 54 & 2 & \mathrm{~A} 53 & 1 & \mathrm{D} 52 \\ \mathrm{H} & 2 & \mathrm{~B} 55 & 1 & \mathrm{~A} 54 & 14 & \mathrm{D} 53 \\ \mathrm{H} & 22 & \mathrm{~B} 56 & 9 & \mathrm{~A} 55 & 2 & \mathrm{D} 54 \\ \mathrm{H} & 17 & \mathrm{~B} 57 & 11 & \mathrm{~A} 56 & 9 & \mathrm{D} 55 \\ \mathrm{H} & 21 & \mathrm{~B} 58 & 7 & \mathrm{~A} 57 & 3 & \mathrm{D} 56 \\ \mathrm{H} & 18 & \mathrm{~B} 59 & 10 & \mathrm{~A} 58 & 7 & \mathrm{D} 57 \\ \mathrm{H} & 6 & \mathrm{~B} 60 & 5 & \mathrm{~A} 59 & 2 & \mathrm{D} 58 \\ \mathrm{H} & 1 & \mathrm{~B} 61 & 14 & \mathrm{~A} 60 & 3 & \mathrm{D} 59 \\ \mathrm{Si} & 15 & \mathrm{~B} 62 & 2 & \mathrm{~A} 61 & 1 & \mathrm{D} 60 \\ \mathrm{Si} & 35 & \mathrm{~B} 63 & 4 & \mathrm{~A} 62 & 2 & \mathrm{D} 61 \\ \mathrm{C} & 37 & \mathrm{~B} 64 & 20 & \mathrm{~A} 63 & 12 & \mathrm{D} 62 \\ \mathrm{C} & 8 & \mathrm{~B} 65 & 2 & \mathrm{~A} 64 & 1 & \mathrm{D} 63 \\ \mathrm{H} & 63 & \mathrm{~B} 66 & 15 & \mathrm{~A} 65 & 2 & \mathrm{D} 64 \\ \mathrm{H} & 64 & \mathrm{~B} 67 & 35 & \mathrm{~A} 66 & 4 & \mathrm{D} 65 \\ \mathrm{H} & 64 & \mathrm{~B} 68 & 35 & \mathrm{~A} 67 & 4 & \mathrm{D} 66 \\ \mathrm{H} & 63 & \mathrm{~B} 69 & 15 & \mathrm{~A} 68 & 2 & \mathrm{D} 67 \\ \mathrm{C} & 64 & \mathrm{~B} 70 & 35 & \mathrm{~A} 69 & 4 & \mathrm{D} 68 \\ \mathrm{H} & 65 & \mathrm{~B} 71 & 37 & \mathrm{~A} 70 & 20 & \mathrm{D} 69 \\ \mathrm{H} & 65 & \mathrm{~B} 72 & 37 & \mathrm{~A} 71 & 20 & \mathrm{D} 70 \\ \mathrm{H} & 66 & \mathrm{~B} 73 & 8 & \mathrm{~A} 72 & 2 & \mathrm{D} 71 \\ \mathrm{H} & 66 & \mathrm{~B} 74 & 8 & \mathrm{~A} 73 & 2 & \mathrm{D} 72 \\ \mathrm{Si} & 66 & \mathrm{~B} 75 & 8 & \mathrm{~A} 74 & 2 & \mathrm{D} 73 \\ \mathrm{H} & 76 & \mathrm{~B} 76 & 66 & \mathrm{~A} 75 & 8 & \mathrm{D} 74 \\ \mathrm{H} & 71 & \mathrm{~B} 77 & 64 & \mathrm{~A} 76 & 35 & \mathrm{D} 75 \\ \mathrm{C} & 4 & \mathrm{~B} 78 & 2 & \mathrm{~A} 77 & 1 & \mathrm{D} 76 \\ \mathrm{H} & 79 & \mathrm{~B} 79 & 4 & \mathrm{~A} 78 & 2 & \mathrm{D} 77 \\ \mathrm{H} & 79 & \mathrm{~B} 80 & 4 & \mathrm{~A} 79 & 2 & \mathrm{D} 78 \\ \mathrm{H} & 54 & \mathrm{~B} 81 & 53 & \mathrm{~A} 80 & 3 & \mathrm{D} 79 \\ \mathrm{H} & 79 & \mathrm{~B} 82 & 4 & \mathrm{~A} 81 & 2 & \mathrm{D} 80\end{array}$

$\begin{array}{ll}\text { B1 } & 6.23695371 \\ \text { B2 } & 3.12466288 \\ \text { B3 } & 3.12492341 \\ \text { B4 } & 3.123748 \\ \text { B5 } & 3.11360127 \\ \text { B6 } & 3.15242921 \\ \text { B7 } & 3.14264496 \\ \text { B8 } & 3.15080112 \\ \text { B9 } & 3.14880025 \\ \text { B10 } & 3.15449541 \\ \text { B11 } & 3.13241433\end{array}$




\begin{tabular}{|c|c|}
\hline B12 & 1.90864347 \\
\hline B13 & 1.90534656 \\
\hline B14 & 1.90920433 \\
\hline B15 & 1.9106695 \\
\hline B16 & 1.90549562 \\
\hline B17 & 1.90663972 \\
\hline B18 & 1.90945671 \\
\hline B19 & 1.90657797 \\
\hline B20 & 1.90315855 \\
\hline B21 & 1.89975592 \\
\hline B22 & 1.48965657 \\
\hline B23 & 1.48886898 \\
\hline B24 & 1.49044657 \\
\hline B25 & 1.48935948 \\
\hline B26 & 1.10471968 \\
\hline B27 & 1.48937652 \\
\hline B28 & 1.10077657 \\
\hline B29 & 1.10075451 \\
\hline B30 & 1.10294289 \\
\hline B31 & 1.10455576 \\
\hline B32 & 1.10050522 \\
\hline B33 & 1.10101112 \\
\hline B34 & 1.93631945 \\
\hline B35 & 1.91121155 \\
\hline B36 & 1.91170394 \\
\hline B37 & 1.90935512 \\
\hline B38 & 1.9024026 \\
\hline B39 & 1.90653681 \\
\hline B40 & 1.09904874 \\
\hline B41 & 1.10059757 \\
\hline B42 & 1.49062268 \\
\hline B43 & 1.48861562 \\
\hline B44 & 1.4920251 \\
\hline B45 & 1.49201658 \\
\hline B46 & 1.10126326 \\
\hline B47 & 1.10123542 \\
\hline B48 & 1.10075061 \\
\hline B49 & 1.4915356 \\
\hline B50 & 1.91055093 \\
\hline B51 & 1.90942482 \\
\hline B52 & 1.91823329 \\
\hline B53 & 1.91381942 \\
\hline B54 & 1.49049547 \\
\hline B55 & 1.49118893 \\
\hline B56 & 1.09913163 \\
\hline B57 & 1.09906535 \\
\hline B58 & 1.09941758 \\
\hline B59 & 1.09908069 \\
\hline B60 & 1.49048433 \\
\hline B61 & 1.49078801 \\
\hline B62 & 1.9113737 \\
\hline B63 & 1.91175397 \\
\hline
\end{tabular}




\begin{tabular}{|c|c|}
\hline B64 & 1.90737225 \\
\hline B65 & 1.90659095 \\
\hline B66 & 1.48848057 \\
\hline B67 & 1.49035091 \\
\hline B68 & 1.48845438 \\
\hline B69 & 1.49046071 \\
\hline B70 & 1.90968814 \\
\hline B71 & 1.10076914 \\
\hline B72 & 1.09877357 \\
\hline B73 & 1.10083295 \\
\hline B74 & 1.09876146 \\
\hline B75 & 1.90454905 \\
\hline B76 & 1.49154792 \\
\hline B77 & 1.1008333 \\
\hline B78 & 1.90031252 \\
\hline B79 & 1.09563977 \\
\hline B80 & 1.09538386 \\
\hline B81 & 1.49083547 \\
\hline B82 & 1.09547668 \\
\hline A1 & 60.3985892 \\
\hline$A 2$ & 60.2814074 \\
\hline A3 & 59.96071561 \\
\hline A4 & 120.1180162 \\
\hline A5 & 60.67280944 \\
\hline$A 6$ & 90.82283311 \\
\hline A7 & 60.90594021 \\
\hline A8 & 90.22948376 \\
\hline A9 & 119.6288691 \\
\hline A10 & 90.30442162 \\
\hline A11 & 35.35788672 \\
\hline A12 & 35.0643815 \\
\hline A13 & 90.85770531 \\
\hline A14 & 121.4800106 \\
\hline A15 & 34.13570145 \\
\hline A16 & 146.5416694 \\
\hline A17 & 72.46894057 \\
\hline A18 & 121.4436956 \\
\hline A19 & 122.9357033 \\
\hline A20 & 75.28209501 \\
\hline A21 & 110.2257498 \\
\hline A22 & 90.30543783 \\
\hline A23 & 88.98135511 \\
\hline A24 & 90.33554663 \\
\hline A25 & 107.2155325 \\
\hline A26 & 88.99419571 \\
\hline A27 & 109.0221151 \\
\hline A28 & 108.2908169 \\
\hline A29 & 108.3601459 \\
\hline A30 & 107.4669778 \\
\hline A31 & 109.1951214 \\
\hline A32 & 108.4688791 \\
\hline A33 & 144.5375037 \\
\hline
\end{tabular}




\begin{tabular}{ll} 
A34 & 146.6052331 \\
A35 & 111.6359859 \\
A36 & 111.6411974 \\
A37 & 108.3644683 \\
A38 & 110.8960034 \\
A39 & 110.6814595 \\
A40 & 109.1472346 \\
A41 & 110.4476997 \\
A42 & 110.3536357 \\
A43 & 110.500461 \\
A44 & 121.8178193 \\
A45 & 107.6084554 \\
A46 & 108.0689729 \\
A47 & 108.1054229 \\
A48 & 145.4595358 \\
A49 & 108.5718294 \\
A50 & 36.11312732 \\
A51 & 89.87346829 \\
A52 & 110.2732459 \\
A53 & 90.0476681 \\
A54 & 145.6689508 \\
A55 & 110.502918 \\
A56 & 110.993299 \\
A57 & 110.5275918 \\
A58 & 109.9314911 \\
A59 & 145.9159267 \\
A60 & 110.7180693 \\
A61 & 110.2284657 \\
A62 & 109.0270865 \\
A63 & 108.5922279 \\
A64 & 125.3566403 \\
A65 & 110.766029 \\
A66 & 109.9540258 \\
A67 & 110.6814488 \\
D1 & 110.0220489 \\
A68 & 109.296205 \\
A69 & 111.0352965 \\
A70 & 108.0157387 \\
A71 & 110.0771132 \\
A72 & 108.0039563 \\
A73 & 110.0758336 \\
A74 & 111.7218846 \\
A75 & 111.5496859 \\
A76 & 107.9638165 \\
\hline & 90.25632532 \\
A78 & 111.05412 \\
\hline & 111.5952142 \\
\hline
\end{tabular}




$\begin{array}{ll}\text { D5 } & -54.35051215 \\ \text { D6 } & -109.1082648 \\ \text { D7 } & -54.37737111 \\ \text { D8 } & -69.94345952 \\ \text { D9 } & 54.33324609 \\ \text { D10 } & 142.1323596 \\ \text { D11 } & -87.799067 \\ \text { D12 } & 1.74596961 \\ \text { D13 } & -13.6888881 \\ \text { D14 } & -109.5536475 \\ \text { D15 } & 163.1627898 \\ \text { D16 } & -144.8243505 \\ \text { D17 } & -164.6299641 \\ \text { D18 } & -43.73605895 \\ \text { D19 } & 142.5899682 \\ \text { D20 } & 56.55185004 \\ \text { D21 } & 112.1358392 \\ \text { D22 } & 126.2021335 \\ \text { D23 } & -88.87939352 \\ \text { D24 } & 143.9033332 \\ \text { D25 } & -89.77091013 \\ \text { D26 } & -119.6596729 \\ \text { D27 } & 60.26658954 \\ \text { D28 } & 178.887737 \\ \text { D29 } & -143.965859 \\ \text { D30 } & -138.8950368 \\ \text { D31 } & -176.6807499 \\ \text { D32 } & -144.1122691 \\ \text { D33 } & 0.81035325 \\ \text { D34 } & -26.80460128 \\ \text { D35 } & -61.90128408 \\ \text { D36 } & -178.533856 \\ \text { D37 } & 179.3429321 \\ \text { D38 } & 174.7710776 \\ \text { D56 } & 57.51704687 \\ \text { D39 } & -177.6577624 \\ \text { D54 } & -59.53794311 \\ \text { D40 } & -56.317336 \\ \text { D41 } & 111.5786947 \\ \text { D42 } & 61.39967194 \\ \text { D43 } & -117.3095325 \\ \text { D44 } & 117.4224534 \\ \text { D45 } & -104.0508683 \\ \text { D46 } & -63.63811831 \\ \text { D47 } & -123.4933319 \\ \text { D48 } & -123.6994095 \\ \text { D59 } & -27.76330527 \\ \text { D5 } & \\ \text { D5 } & \end{array}$




$\begin{array}{ll}\text { D57 } & -55.97921494 \\ \text { D58 } & 149.3345801 \\ \text { D59 } & 175.3973991 \\ \text { D60 } & 149.5368392 \\ \text { D61 } & -60.67368947 \\ \text { D62 } & -178.2588684 \\ \text { D63 } & 165.2435101 \\ \text { D64 } & -59.02971388 \\ \text { D65 } & -178.6207151 \\ \text { D66 } & -60.52071304 \\ \text { D67 } & 59.08141777 \\ \text { D68 } & 60.44803912 \\ \text { D69 } & 59.61517649 \\ \text { D70 } & 175.7985336 \\ \text { D71 } & 147.145078 \\ \text { D72 } & 31.01377836 \\ \text { D73 } & -92.94325203 \\ \text { D74 } & 176.4491745 \\ \text { D75 } & -179.691156 \\ \text { D76 } & 89.78410697 \\ \text { D77 } & -30.87090716 \\ \text { D78 } & 89.34272402 \\ \text { D79 } & -60.9034913 \\ \text { D80 } & -150.4694348\end{array}$

\section{$\mathrm{CH}_{2}$ (ads)}

\begin{tabular}{|c|c|c|c|c|c|c|}
\hline $\mathrm{Si}$ & & & & & & \\
\hline Si & 1 & B1 & & & & \\
\hline Si & 1 & B2 & 2 & A1 & & \\
\hline Si & 2 & B3 & 1 & $A 2$ & 3 & D1 \\
\hline Si & 2 & B4 & 1 & A3 & 3 & D2 \\
\hline Si & 5 & B5 & 2 & A4 & 1 & D3 \\
\hline Si & 3 & B6 & 1 & A5 & 6 & D4 \\
\hline Si & 2 & B7 & 1 & A6 & 3 & D5 \\
\hline Si & 8 & B8 & 2 & A7 & 1 & D6 \\
\hline $\mathrm{Si}$ & 7 & B9 & 3 & A8 & 1 & D7 \\
\hline Si & 9 & B10 & 8 & A9 & 2 & D8 \\
\hline Si & 3 & B11 & 1 & A10 & 6 & D9 \\
\hline C & 6 & B12 & 5 & A11 & 2 & D10 \\
\hline C & 1 & B13 & 3 & $\mathrm{~A} 12$ & 4 & D11 \\
\hline C & 2 & B14 & 1 & A13 & 14 & D12 \\
\hline C & 12 & B15 & 3 & A14 & 1 & D13 \\
\hline C & 11 & B16 & 9 & A15 & 8 & D14 \\
\hline C & 10 & B17 & 7 & A16 & 3 & D15 \\
\hline C & 7 & B18 & 3 & A17 & 1 & D16 \\
\hline C & 12 & B19 & 3 & A18 & 1 & D17 \\
\hline C & 7 & B20 & 3 & A19 & 1 & D18 \\
\hline C & 9 & B21 & 8 & $\mathrm{~A} 20$ & 2 & D19 \\
\hline $\mathrm{H}$ & 1 & B22 & 14 & A21 & 3 & D20 \\
\hline $\mathrm{H}$ & 2 & B23 & 1 & $\mathrm{~A} 22$ & 14 & D21 \\
\hline
\end{tabular}




\begin{tabular}{|c|c|c|c|c|c|c|}
\hline $\mathrm{H}$ & 3 & B24 & 1 & A23 & 14 & D22 \\
\hline $\mathrm{H}$ & 5 & B25 & 2 & A24 & 1 & D23 \\
\hline $\mathrm{H}$ & 16 & B26 & 12 & A25 & 3 & D24 \\
\hline $\mathrm{H}$ & 6 & B27 & 5 & A26 & 2 & D25 \\
\hline $\mathrm{H}$ & 17 & B28 & 11 & A27 & 9 & D26 \\
\hline $\mathrm{H}$ & 18 & B29 & 10 & A28 & 7 & D27 \\
\hline $\mathrm{H}$ & 19 & B30 & 7 & A29 & 3 & D28 \\
\hline $\mathrm{H}$ & 20 & B31 & 12 & A30 & 3 & D29 \\
\hline $\mathrm{H}$ & 21 & B32 & 7 & A31 & 3 & D30 \\
\hline $\mathrm{H}$ & 22 & B33 & 9 & A32 & 8 & D31 \\
\hline C & 4 & B34 & 2 & A33 & 1 & D32 \\
\hline C & 3 & B35 & 1 & A34 & 14 & D33 \\
\hline Si & 20 & B36 & 12 & A35 & 3 & D34 \\
\hline Si & 19 & B37 & 7 & A36 & 3 & D35 \\
\hline C & 38 & B38 & 19 & A37 & 7 & D36 \\
\hline Si & 36 & B39 & 3 & A38 & 1 & D37 \\
\hline $\mathrm{H}$ & 39 & B40 & 38 & A39 & 19 & D38 \\
\hline $\mathrm{H}$ & 39 & B41 & 38 & A40 & 19 & D39 \\
\hline $\mathrm{H}$ & 40 & B42 & 36 & A41 & 3 & D40 \\
\hline $\mathrm{H}$ & 40 & B43 & 36 & A42 & 3 & D41 \\
\hline $\mathrm{H}$ & 38 & B44 & 19 & A43 & 7 & D42 \\
\hline $\mathrm{H}$ & 7 & B45 & 3 & A44 & 1 & D43 \\
\hline $\mathrm{H}$ & 36 & B46 & 3 & A45 & 1 & D44 \\
\hline $\mathrm{H}$ & 14 & B47 & 1 & A46 & 3 & D45 \\
\hline $\mathrm{H}$ & 13 & B48 & 6 & A47 & 5 & D46 \\
\hline $\mathrm{H}$ & 11 & B49 & 9 & A48 & 8 & D47 \\
\hline C & 1 & B50 & 14 & A49 & 3 & D48 \\
\hline C & 2 & B51 & 1 & A50 & 14 & D49 \\
\hline C & 3 & B52 & 1 & A51 & 14 & D50 \\
\hline $\mathrm{Si}$ & 53 & B53 & 3 & A52 & 1 & D51 \\
\hline $\mathrm{H}$ & 5 & B54 & 2 & A53 & 1 & D52 \\
\hline $\mathrm{H}$ & 2 & B55 & 1 & A54 & 14 & D53 \\
\hline $\mathrm{H}$ & 22 & B56 & 9 & A55 & 8 & D54 \\
\hline $\mathrm{H}$ & 17 & B57 & 11 & A56 & 9 & D55 \\
\hline $\mathrm{H}$ & 21 & B58 & 7 & A57 & 3 & D56 \\
\hline $\mathrm{H}$ & 18 & B59 & 10 & A58 & 7 & D57 \\
\hline $\mathrm{H}$ & 6 & $\mathrm{~B} 60$ & 5 & A59 & 2 & D58 \\
\hline $\mathrm{H}$ & 1 & B61 & 14 & A60 & 3 & D59 \\
\hline Si & 15 & B62 & 2 & A61 & 1 & D60 \\
\hline Si & 35 & B63 & 4 & A62 & 2 & D61 \\
\hline C & 37 & B64 & 20 & A63 & 12 & D62 \\
\hline C & 8 & B65 & 2 & A64 & 1 & D63 \\
\hline $\mathrm{H}$ & 63 & B66 & 15 & A65 & 2 & D64 \\
\hline $\mathrm{H}$ & 64 & B67 & 35 & A66 & 4 & D65 \\
\hline $\mathrm{H}$ & 64 & B68 & 35 & A67 & 4 & D66 \\
\hline $\mathrm{H}$ & 63 & B69 & 15 & A68 & 2 & D67 \\
\hline C & 64 & B70 & 35 & A69 & 4 & D68 \\
\hline $\mathrm{H}$ & 65 & B71 & 37 & A70 & 20 & D69 \\
\hline $\mathrm{H}$ & 65 & B72 & 37 & A71 & 20 & D70 \\
\hline $\mathrm{H}$ & 66 & B73 & 8 & A72 & 2 & D71 \\
\hline $\mathrm{H}$ & 66 & B74 & 8 & A73 & 2 & D72 \\
\hline Si & 66 & B75 & 8 & A74 & 2 & D73 \\
\hline
\end{tabular}




$\begin{array}{lllllll}\mathrm{H} & 76 & \mathrm{~B} 76 & 66 & \text { A75 } & 8 & \text { D74 } \\ \mathrm{H} & 71 & \text { B77 } & 64 & \text { A76 } & 35 & \text { D75 } \\ \mathrm{C} & 4 & \text { B78 } & 2 & \text { A77 } & 1 & \text { D76 } \\ \mathrm{H} & 79 & \text { B79 } & 4 & \text { A78 } & 2 & \text { D77 } \\ \text { H } & 79 & \text { B80 } & 4 & \text { A79 } & 2 & \text { D78 } \\ \text { H } & 54 & \text { B81 } & 53 & \text { A80 } & 3 & \text { D79 }\end{array}$

B1

B2

B3

B4

B5

B6

B7

B8

B9

B10

B11

B12

B13

B14

B15

B16

B17

B18

B19

B20

B21

B22

B23

B24

B25

B26

B27

B28

B29

B30

B31

B32

B33

B34

B35

B36

B37

B38

B39

B40

B41

B42

B43
6.22824254

3.12490123

3.11769344

3.12555538

3.11415772

3.15353153

3.15295864

3.15522111

3.14998184

3.15472409

3.13836119

1.9085515

1.90510444

1.90982966

1.91019619

1.90539133

1.90657123

1.9096806

1.90777412

1.90354238

1.89963673

1.4897187

1.4885418

1.49023158

1.48931876

1.10471142

1.48940192

1.10076809

1.1007567

1.10294982

1.10460165

1.10052632

1.10098491

1.93481672

1.91026996

1.9128069

1.91023303

1.90285581

1.90681209

1.09914228

1.10058363

1.49113467

1.48805051 


\begin{tabular}{ll} 
B44 & 1.49201457 \\
B45 & 1.49200453 \\
B46 & 1.10124273 \\
B47 & 1.10123652 \\
B48 & 1.10075443 \\
B49 & 1.49153045 \\
B50 & 1.91061018 \\
B51 & 1.91013231 \\
B52 & 1.91833739 \\
B53 & 1.9136359 \\
B54 & 1.49042434 \\
B55 & 1.49149626 \\
B56 & 1.09925739 \\
B57 & 1.09906132 \\
B58 & 1.09942028 \\
B59 & 1.09907853 \\
B60 & 1.49046218 \\
B61 & 1.49077471 \\
B62 & 1.91107839 \\
B63 & 1.91121531 \\
B64 & 1.90727209 \\
B65 & 1.90624271 \\
B66 & 1.48849438 \\
B67 & 1.49022568 \\
B68 & 1.48888723 \\
B69 & 1.49049944 \\
B70 & 1.9084041 \\
B71 & 1.1007758 \\
B72 & 1.09885603 \\
A14 & 1.10080256 \\
A73 & 1.09889069 \\
B74 & 1.90439814 \\
B75 & 1.49151902 \\
B76 & 1.10080647 \\
B77 & 1.86766338 \\
B78 & 1.0898424 \\
B79 & 1.08975628 \\
B80 & 1.49144874 \\
B81 & 60.25623618 \\
A1 & 60.32473907 \\
A3 & 60.11405267 \\
A4 & 119.8942606 \\
\hline & 90.64600037 \\
A5 & 60.073395095 \\
\hline
\end{tabular}



33.89266089

110.2349437

107.3164398

A26

88.99797365

A27

109.0399115

A28

108.2985062

A29

108.3501745

A30

107.4092077

A31

109.169239

A32

108.5250046

A33

144.6288625

146.5929298

111.6990655

A35

111.6360279

A36

108.3498087

A37

110.6662882

A39

110.6181862

A40

109.1486623

A41

110.3448199

A42

110.5075514

A43

110.405434

A44

121.8876337

A45

107.6556664

A46

108.0890257

A47

108.1034335

A48

145.4587915

A49

108.5585803

A50

36.45644291

A51

89.82895668

A52

110.1555727

A53

90.32495957

A54

145.9290576

A55

110.4217715

110.978897

110.5109637

109.9487373

145.9153887

110.7620286

110.0097861

109.2623244

108.5812353

125.2772693

110.4658621

109.9194789 


\begin{tabular}{|c|c|}
\hline A67 & 110.5484076 \\
\hline A68 & 109.9924038 \\
\hline A69 & 108.5654476 \\
\hline A70 & 108.0832343 \\
\hline A71 & 110.046337 \\
\hline A72 & 108.1191566 \\
\hline A73 & 109.9736165 \\
\hline A74 & 111.7114168 \\
\hline A75 & 111.5267518 \\
\hline A76 & 108.0462181 \\
\hline A77 & 90.23301704 \\
\hline A78 & 122.0972651 \\
\hline A79 & 122.7855673 \\
\hline A80 & 109.5382584 \\
\hline D1 & 0.39291695 \\
\hline D2 & -179.6768661 \\
\hline D3 & 0.13656947 \\
\hline D4 & 109.3723906 \\
\hline D5 & -54.67483828 \\
\hline D6 & -55.34938723 \\
\hline D7 & -54.40525896 \\
\hline D8 & 27.79525413 \\
\hline D9 & 54.52863435 \\
\hline D10 & 142.3873464 \\
\hline D11 & -143.0649499 \\
\hline D12 & 1.03929034 \\
\hline D13 & -14.00009144 \\
\hline D14 & -137.5440625 \\
\hline D15 & 163.0759129 \\
\hline D16 & -144.91426 \\
\hline D17 & -164.6077111 \\
\hline D18 & -43.8056561 \\
\hline D19 & -109.9990011 \\
\hline D20 & 56.55843914 \\
\hline D21 & 111.0391832 \\
\hline D22 & 126.714826 \\
\hline D23 & -88.90961264 \\
\hline D24 & 144.1720466 \\
\hline D25 & -89.4873785 \\
\hline D26 & -119.6625984 \\
\hline D27 & 60.34366479 \\
\hline D28 & 179.1075166 \\
\hline D29 & -144.1265996 \\
\hline D30 & -138.8425328 \\
\hline D31 & -119.7031241 \\
\hline D32 & -145.4905877 \\
\hline D33 & 0.86713334 \\
\hline D34 & -27.00055431 \\
\hline D35 & -61.7431882 \\
\hline D36 & -178.4659255 \\
\hline D37 & 179.2012896 \\
\hline D38 & 174.8928679 \\
\hline
\end{tabular}




$\begin{array}{ll}\text { D39 } & 57.65334612 \\ \text { D40 } & -177.0461655 \\ \text { D41 } & -58.38417435 \\ \text { D42 } & -56.42582518 \\ \text { D43 } & 111.4926858 \\ \text { D44 } & 61.3868254 \\ \text { D45 } & -117.3365163 \\ \text { D46 } & 117.4279805 \\ \text { D47 } & -132.0324831 \\ \text { D48 } & -63.58785084 \\ \text { D49 } & -123.3689474 \\ \text { D50 } & -123.3956914 \\ \text { D51 } & -28.15953354 \\ \text { D52 } & 163.4937082 \\ \text { D53 } & -127.9165842 \\ \text { D54 } & 123.6303401 \\ \text { D55 } & 123.0845451 \\ \text { D56 } & 103.9959184 \\ \text { D57 } & -55.91740806 \\ \text { D58 } & 149.6135921 \\ \text { D59 } & 175.4353412 \\ \text { D60 } & 148.8896705 \\ \text { D61 } & -59.53976182 \\ \text { D62 } & -178.3274472 \\ \text { D63 } & 165.1107586 \\ \text { D64 } & -59.02973637 \\ \text { D65 } & -178.2848989 \\ \text { D66 } & -60.20673407 \\ \text { D67 } & 59.31698889 \\ \text { D68 } & 60.55908158 \\ \text { D69 } & 59.65566198 \\ \text { D70 } & 175.8542363 \\ \text { D71 } & 147.3249355 \\ \text { D72 } & 31.17488684 \\ \text { D73 } & -92.61468241 \\ \text { D74 } & 176.6370447 \\ \text { D75 } & -179.8071393 \\ \text { D76 } & 89.04232718 \\ \text { D77 } & -73.62401135 \\ \text { D78 } & 105.0392254\end{array}$

\section{$\mathrm{C}_{2} \mathrm{H}_{4}$ (ads)}

$\mathrm{Si}$

$\begin{array}{lll}\text { Si } & 1 & \text { B1 }\end{array}$

$\begin{array}{lll}\text { Si } & 1 & B 2\end{array}$

$\begin{array}{lll}\mathrm{Si} & 3 & \mathrm{~B} 3\end{array}$

2

A1

$\begin{array}{lll}\mathrm{Si} & 2 & \text { B4 }\end{array}$

B5

B6

B7

1

1

A2

A3

D1

A4

1

$\begin{array}{lll}\text { A5 } & 6 & \text { D4 }\end{array}$

$\mathrm{Si}$

2

A6

D5 


\begin{tabular}{|c|c|c|c|c|c|c|}
\hline Si & 2 & B8 & 1 & A7 & 3 & D6 \\
\hline Si & 1 & B9 & 3 & A8 & 4 & D7 \\
\hline Si & 10 & B10 & 1 & A9 & 3 & D8 \\
\hline Si & 7 & B11 & 3 & A10 & 1 & D9 \\
\hline C & 5 & B12 & 2 & A11 & 1 & D10 \\
\hline C & 3 & B13 & 1 & A12 & 6 & D11 \\
\hline C & 2 & B14 & 1 & A13 & 14 & D12 \\
\hline C & 12 & B15 & 7 & A14 & 3 & D13 \\
\hline C & 9 & B16 & 2 & A15 & 1 & D14 \\
\hline C & 11 & B17 & 10 & A16 & 1 & D15 \\
\hline C & 7 & B18 & 3 & A17 & 1 & D16 \\
\hline C & 12 & B19 & 7 & A18 & 3 & D17 \\
\hline C & 7 & B20 & 3 & A19 & 1 & D18 \\
\hline C & 8 & B21 & 2 & A20 & 1 & D19 \\
\hline $\mathrm{H}$ & 1 & B22 & 14 & A21 & 3 & D20 \\
\hline $\mathrm{H}$ & 2 & B23 & 1 & $\mathrm{~A} 22$ & 14 & D21 \\
\hline $\mathrm{H}$ & 3 & B24 & 1 & $\mathrm{~A} 23$ & 14 & $\mathrm{D} 22$ \\
\hline $\mathrm{H}$ & 5 & B25 & 2 & A24 & 1 & $\mathrm{D} 23$ \\
\hline $\mathrm{H}$ & 16 & B26 & 12 & A25 & 7 & D24 \\
\hline $\mathrm{H}$ & 6 & B27 & 5 & A26 & 2 & D25 \\
\hline $\mathrm{H}$ & 17 & B28 & 9 & $\mathrm{~A} 27$ & 2 & $\mathrm{D} 26$ \\
\hline $\mathrm{H}$ & 18 & B29 & 11 & A28 & 10 & D27 \\
\hline $\mathrm{H}$ & 19 & B30 & 7 & A29 & 3 & D28 \\
\hline $\mathrm{H}$ & 20 & B31 & 12 & $\mathrm{~A} 30$ & 7 & D29 \\
\hline $\mathrm{H}$ & 21 & B32 & 7 & A31 & 3 & D30 \\
\hline $\mathrm{H}$ & 22 & B33 & 8 & $\mathrm{~A} 32$ & 2 & D31 \\
\hline C & 4 & B34 & 3 & A33 & 1 & D32 \\
\hline C & 3 & B35 & 1 & A34 & 14 & D33 \\
\hline Si & 20 & B36 & 12 & A35 & 7 & D34 \\
\hline $\mathrm{Si}$ & 19 & B37 & 7 & A36 & 3 & D35 \\
\hline C & 38 & B38 & 19 & A37 & 7 & D36 \\
\hline Si & 36 & B39 & 3 & A38 & 1 & D37 \\
\hline $\mathrm{H}$ & 39 & B40 & 38 & A39 & 19 & D38 \\
\hline $\mathrm{H}$ & 39 & B41 & 38 & A40 & 19 & D39 \\
\hline $\mathrm{H}$ & 40 & B42 & 36 & A41 & 3 & D40 \\
\hline $\mathrm{H}$ & 40 & B43 & 36 & A42 & 3 & D41 \\
\hline $\mathrm{H}$ & 38 & B44 & 19 & A43 & 7 & D42 \\
\hline $\mathrm{H}$ & 7 & B45 & 3 & A44 & 1 & D43 \\
\hline $\mathrm{H}$ & 36 & B46 & 3 & A45 & 1 & D44 \\
\hline $\mathrm{H}$ & 14 & B47 & 3 & A46 & 1 & D45 \\
\hline $\mathrm{H}$ & 13 & B48 & 5 & A47 & 2 & D46 \\
\hline $\mathrm{H}$ & 11 & B49 & 10 & A48 & 1 & D47 \\
\hline C & 6 & B50 & 5 & A49 & 2 & D48 \\
\hline C & 2 & B51 & 1 & A50 & 14 & D49 \\
\hline C & 12 & B52 & 7 & A51 & 3 & D50 \\
\hline Si & 53 & B53 & 12 & A52 & 7 & D51 \\
\hline $\mathrm{H}$ & 5 & B54 & 2 & A53 & 1 & D52 \\
\hline $\mathrm{H}$ & 2 & B55 & 1 & A54 & 14 & D53 \\
\hline $\mathrm{H}$ & 22 & B56 & 8 & A55 & 2 & D54 \\
\hline $\mathrm{H}$ & 17 & B57 & 9 & A56 & 2 & D55 \\
\hline $\mathrm{H}$ & 21 & B58 & 7 & A57 & 3 & D56 \\
\hline $\mathrm{H}$ & 18 & B59 & 11 & A58 & 10 & D57 \\
\hline
\end{tabular}




$\begin{array}{lllllll}\mathrm{H} & 6 & \mathrm{~B} 60 & 5 & \mathrm{~A} 59 & 2 & \mathrm{D} 58 \\ \mathrm{H} & 1 & \mathrm{~B} 61 & 14 & \mathrm{~A} 60 & 3 & \mathrm{D} 59 \\ \mathrm{Si} & 15 & \mathrm{~B} 62 & 2 & \mathrm{~A} 61 & 1 & \mathrm{D} 60 \\ \mathrm{Si} & 35 & \mathrm{~B} 63 & 4 & \mathrm{~A} 62 & 3 & \mathrm{D} 61 \\ \mathrm{C} & 37 & \mathrm{~B} 64 & 20 & \mathrm{~A} 63 & 12 & \mathrm{D} 62 \\ \mathrm{C} & 8 & \mathrm{~B} 65 & 2 & \mathrm{~A} 64 & 1 & \mathrm{D} 63 \\ \mathrm{H} & 63 & \mathrm{~B} 66 & 15 & \mathrm{~A} 65 & 2 & \mathrm{D} 64 \\ \mathrm{H} & 64 & \mathrm{~B} 67 & 35 & \mathrm{~A} 66 & 4 & \mathrm{D} 65 \\ \mathrm{H} & 64 & \mathrm{~B} 68 & 35 & \mathrm{~A} 67 & 4 & \mathrm{D} 66 \\ \mathrm{H} & 63 & \mathrm{~B} 69 & 15 & \mathrm{~A} 68 & 2 & \mathrm{D} 67 \\ \mathrm{C} & 63 & \mathrm{~B} 70 & 15 & \mathrm{~A} 69 & 2 & \mathrm{D} 68 \\ \mathrm{H} & 65 & \mathrm{~B} 71 & 37 & \mathrm{~A} 70 & 20 & \mathrm{D} 69 \\ \mathrm{H} & 65 & \mathrm{~B} 72 & 37 & \mathrm{~A} 71 & 20 & \mathrm{D} 70 \\ \mathrm{H} & 66 & \mathrm{~B} 73 & 8 & \mathrm{~A} 72 & 2 & \mathrm{D} 71 \\ \mathrm{H} & 66 & \mathrm{~B} 74 & 8 & \mathrm{~A} 73 & 2 & \mathrm{D} 72 \\ \mathrm{Si} & 65 & \mathrm{~B} 75 & 37 & \mathrm{~A} 74 & 20 & \mathrm{D} 73 \\ \mathrm{H} & 76 & \mathrm{~B} 76 & 65 & \mathrm{~A} 75 & 37 & \mathrm{D} 74 \\ \mathrm{H} & 71 & \mathrm{~B} 77 & 63 & \mathrm{~A} 76 & 15 & \mathrm{D} 75 \\ \mathrm{C} & 4 & \mathrm{~B} 78 & 3 & \mathrm{~A} 77 & 1 & \mathrm{D} 76 \\ \mathrm{H} & 79 & \mathrm{~B} 79 & 4 & \mathrm{~A} 78 & 3 & \mathrm{D} 77 \\ \mathrm{H} & 79 & \mathrm{~B} 80 & 4 & \mathrm{~A} 79 & 3 & \mathrm{D} 78 \\ \mathrm{C} & 79 & \mathrm{~B} 81 & 4 & \mathrm{~A} 80 & 3 & \mathrm{D} 79 \\ \mathrm{H} & 82 & \mathrm{~B} 82 & 79 & \mathrm{~A} 81 & 4 & \mathrm{D} 80 \\ \mathrm{H} & 82 & \mathrm{~B} 83 & 79 & \mathrm{~A} 82 & 4 & \mathrm{D} 81\end{array}$

$\begin{array}{ll}\text { B1 } & 6.28553347 \\ \text { B2 } & 3.08509068 \\ \text { B3 } & 3.10689486 \\ \text { B4 } & 3.08441276 \\ \text { B5 } & 3.08847244 \\ \text { B6 } & 3.12044014 \\ \text { B7 } & 3.12099573 \\ \text { B8 } & 3.12084203 \\ \text { B9 } & 3.13796728 \\ \text { B10 } & 3.15294888 \\ \text { B11 } & 3.14489532 \\ \text { B12 } & 1.90271594 \\ \text { B13 } & 1.8994673 \\ \text { B14 } & 1.90054965 \\ \text { B15 } & 1.91266803 \\ \text { B16 } & 1.90716515 \\ \text { B17 } & 1.90197548 \\ \text { B18 } & 1.91993913 \\ \text { B19 } & 1.91268726 \\ \text { B20 } & 1.89942637 \\ \text { B21 } & 1.90641881 \\ \text { B22 } & 1.49038285 \\ \text { B23 } & 1.4875188 \\ \text { B24 } & 1.48838833 \\ \text { B25 } & 1.49065923 \\ \text { B26 } & 1.10448565\end{array}$




\begin{tabular}{|c|c|}
\hline B27 & 1.49059692 \\
\hline B28 & 1.10081199 \\
\hline B29 & 1.10061632 \\
\hline B30 & 1.10295934 \\
\hline B31 & 1.10448868 \\
\hline B32 & 1.10049639 \\
\hline B33 & 1.10122723 \\
\hline B34 & 1.93585541 \\
\hline B35 & 1.89952319 \\
\hline B36 & 1.91539683 \\
\hline B37 & 1.91995262 \\
\hline B38 & 1.89940439 \\
\hline B39 & 1.90632586 \\
\hline B40 & 1.09929996 \\
\hline B41 & 1.10048939 \\
\hline B42 & 1.4906975 \\
\hline B43 & 1.49037689 \\
\hline B44 & 1.49207792 \\
\hline B45 & 1.49207416 \\
\hline B46 & 1.10089218 \\
\hline B47 & 1.10088879 \\
\hline B48 & 1.10047354 \\
\hline B49 & 1.49160413 \\
\hline B50 & 1.90985335 \\
\hline B51 & 1.90052579 \\
\hline B52 & 1.89568095 \\
\hline B53 & 1.89934357 \\
\hline B54 & 1.49071577 \\
\hline B55 & 1.49090007 \\
\hline B56 & 1.09859314 \\
\hline B57 & 1.09935285 \\
\hline B58 & 1.09929926 \\
\hline B59 & 1.09902058 \\
\hline B60 & 1.49056309 \\
\hline B61 & 1.4906972 \\
\hline B62 & 1.90736279 \\
\hline B63 & 1.90987865 \\
\hline B64 & 1.90652512 \\
\hline B65 & 1.90712925 \\
\hline B66 & 1.49066359 \\
\hline B67 & 1.4905672 \\
\hline B68 & 1.49059413 \\
\hline B69 & 1.49070745 \\
\hline B70 & 1.90269524 \\
\hline B71 & 1.10061192 \\
\hline B72 & 1.0990237 \\
\hline B73 & 1.10082009 \\
\hline B74 & 1.09934944 \\
\hline B75 & 1.9019373 \\
\hline B76 & 1.49160397 \\
\hline B77 & 1.10047261 \\
\hline B78 & 1.93598368 \\
\hline
\end{tabular}




\begin{tabular}{|c|c|}
\hline B79 & 1.09654781 \\
\hline B80 & 1.09705371 \\
\hline B81 & 1.598451 \\
\hline B82 & 1.09700894 \\
\hline B83 & 1.09658177 \\
\hline A1 & 61.12125515 \\
\hline $\mathrm{A} 2$ & 117.4049416 \\
\hline A3 & 59.29713265 \\
\hline A4 & 121.3038093 \\
\hline A5 & 62.12431452 \\
\hline A6 & 90.2000645 \\
\hline A7 & 60.42576974 \\
\hline A8 & 89.36034864 \\
\hline A9 & 120.1736587 \\
\hline A10 & 60.33328721 \\
\hline A11 & 144.4988879 \\
\hline A12 & 35.91565476 \\
\hline A13 & 88.51162086 \\
\hline A14 & 89.80051179 \\
\hline A15 & 123.1846124 \\
\hline A16 & 34.16408498 \\
\hline A17 & 72.92142576 \\
\hline A18 & 147.3964345 \\
\hline A19 & 120.9572109 \\
\hline A20 & 75.09340896 \\
\hline A21 & 109.7238189 \\
\hline A22 & 94.06277021 \\
\hline A23 & 87.22765077 \\
\hline A24 & 90.63330022 \\
\hline A25 & 108.9925612 \\
\hline A26 & 88.62620418 \\
\hline A27 & 108.744977 \\
\hline A28 & 109.3973352 \\
\hline A29 & 108.003202 \\
\hline A30 & 108.9875099 \\
\hline A31 & 110.0257245 \\
\hline A32 & 108.0154068 \\
\hline A33 & 88.85952786 \\
\hline A34 & 148.1030884 \\
\hline A35 & 111.2096801 \\
\hline A36 & 111.9829495 \\
\hline A37 & 109.479807 \\
\hline A38 & 108.3027142 \\
\hline A39 & 110.1225552 \\
\hline A40 & 110.0386807 \\
\hline A41 & 111.1434245 \\
\hline A42 & 109.7170104 \\
\hline A43 & 110.0164651 \\
\hline A44 & 122.9738581 \\
\hline A45 & 108.1793851 \\
\hline A46 & 108.1913719 \\
\hline A47 & 108.54835 \\
\hline
\end{tabular}




\begin{tabular}{ll} 
A48 & 145.782868 \\
A49 & 90.29724436 \\
A50 & 34.58420783 \\
A51 & 88.63030973 \\
A52 & 113.1805381 \\
A53 & 88.55416685 \\
A54 & 144.5642326 \\
A55 & 110.785171 \\
A56 & 109.9220527 \\
A57 & 110.1256939 \\
A58 & 111.0593342 \\
A59 & 146.5989296 \\
A60 & 111.1376498 \\
A61 & 108.190323 \\
A62 & 110.7864756 \\
A63 & 108.5872558 \\
A64 & 123.181898 \\
A65 & 109.7873497 \\
A66 & 110.2999638 \\
A67 & 109.7964734 \\
A68 & 110.1023732 \\
A69 & 108.6907752 \\
A70 & 107.7301612 \\
A71 & 109.9875404 \\
A72 & 108.7500396 \\
A73 & 109.9246685 \\
A74 & 111.7625331 \\
A75 & 111.6806228 \\
A76 & 108.5567987 \\
A77 & 83.28755979 \\
A78 & 110.7328916 \\
A79 & 110.1427052 \\
A80 & 109.9626204 \\
A81 & 109.4176879 \\
A82 & 109.9503 \\
D1 & -3.01799987 \\
D2 & -179.8662171 \\
D3 & -0.28676284 \\
D4 & 109.561139 \\
D5 & -51.38422965 \\
D6 & -107.2730527 \\
D7 & -57.90181824 \\
D8 & 126.6489724 \\
D9 & -110.3462529 \\
D10 & 38.56403783 \\
D11 & 142.3647068 \\
D12 & 5.60231754 \\
D13 & 125.028997 \\
D14 & -109.979352 \\
& 107.5166394 \\
& -146.2003589 \\
\hline & -97.95520358
\end{tabular}




\begin{tabular}{|c|c|}
\hline D18 & -43.34990854 \\
\hline D19 & -88.36752776 \\
\hline D20 & 59.15883199 \\
\hline D21 & 116.4650965 \\
\hline D22 & 127.6830803 \\
\hline D23 & -88.54715351 \\
\hline D24 & 88.61004266 \\
\hline D25 & -90.89578597 \\
\hline D26 & -147.3093916 \\
\hline D27 & 119.2272711 \\
\hline D28 & -178.8928266 \\
\hline D29 & -64.21115891 \\
\hline D30 & -138.5021264 \\
\hline D31 & 175.9428759 \\
\hline D32 & 168.0528393 \\
\hline D33 & 5.91776412 \\
\hline D34 & 52.89027635 \\
\hline D35 & -60.09465354 \\
\hline D36 & 177.6083548 \\
\hline D37 & 172.8667674 \\
\hline D38 & 174.6659158 \\
\hline D39 & 57.1955264 \\
\hline D40 & -177.6894097 \\
\hline D41 & -59.16858021 \\
\hline D42 & -59.51990433 \\
\hline D43 & 110.6412643 \\
\hline D44 & 55.83127963 \\
\hline D45 & 117.0540162 \\
\hline D46 & 176.900352 \\
\hline D47 & 103.2496284 \\
\hline D48 & 18.90154931 \\
\hline D49 & -121.7051021 \\
\hline D50 & 19.461996 \\
\hline D51 & 92.83646958 \\
\hline D52 & 164.2068491 \\
\hline D53 & -118.0445864 \\
\hline D54 & -67.35317025 \\
\hline D55 & -30.87558534 \\
\hline D56 & 104.0347626 \\
\hline D57 & -123.2486517 \\
\hline D58 & 148.5470475 \\
\hline D59 & 177.6797151 \\
\hline D60 & 146.4827125 \\
\hline D61 & 150.6979555 \\
\hline D62 & -177.4505895 \\
\hline D63 & 163.1594701 \\
\hline D64 & -61.41513214 \\
\hline D65 & -177.7309498 \\
\hline D66 & -59.50783032 \\
\hline D67 & 56.45119309 \\
\hline D68 & 178.2725589 \\
\hline D69 & 59.23630953 \\
\hline
\end{tabular}




$\begin{array}{ll}\text { D70 } & 175.1752528 \\ \text { D71 } & 147.3300074 \\ \text { D72 } & 30.8935878 \\ \text { D73 } & -60.97576617 \\ \text { D74 } & -177.4281539 \\ \text { D75 } & -178.6728033 \\ \text { D76 } & -67.80992227 \\ \text { D77 } & -175.7144806 \\ \text { D78 } & -58.08666371 \\ \text { D79 } & 62.57122118 \\ \text { D80 } & -121.1447772\end{array}$

